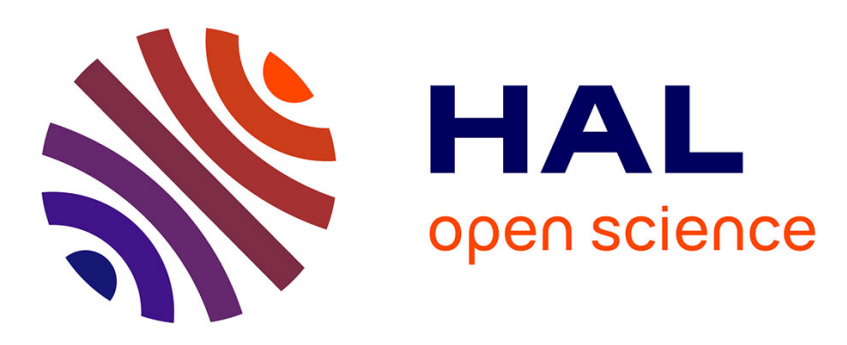

\title{
Tectonic and stratigraphic evolution of the Western Alboran Sea Basin in the last 25 Myrs
}

Damien Do Couto, Christian Gorini, Laurent Jolivet, Noëmie Lebret, Romain Augier, Charles Gumiaux, Elia D 'Acremont, Abdellah Ammar, Haddou Jabour, Jean-Luc Auxietre

\section{To cite this version:}

Damien Do Couto, Christian Gorini, Laurent Jolivet, Noëmie Lebret, Romain Augier, et al.. Tectonic and stratigraphic evolution of the Western Alboran Sea Basin in the last 25 Myrs. Tectonophysics, 2016, 677-678, pp.280-311. 10.1016/j.tecto.2016.03.020 . insu-01291175

\section{HAL Id: insu-01291175 \\ https://hal-insu.archives-ouvertes.fr/insu-01291175}

Submitted on 21 Mar 2016

HAL is a multi-disciplinary open access archive for the deposit and dissemination of scientific research documents, whether they are published or not. The documents may come from teaching and research institutions in France or abroad, or from public or private research centers.
L'archive ouverte pluridisciplinaire HAL, est destinée au dépôt et à la diffusion de documents scientifiques de niveau recherche, publiés ou non, émanant des établissements d'enseignement et de recherche français ou étrangers, des laboratoires publics ou privés. 


\section{Accepted Manuscript}

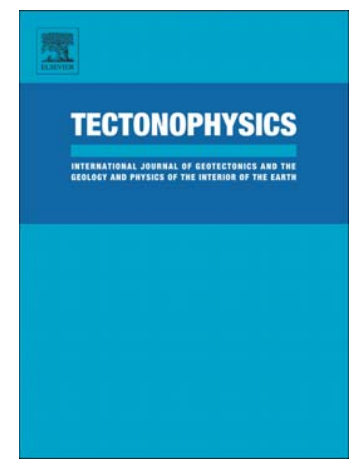

Tectonic and stratigraphic evolution of the Western Alboran Sea Basin in the last 25 Myrs

Damien Do Couto, Christian Gorini, Laurent Jolivet, Noëmie Lebret, Romain Augier, Charles Gumiaux, Elia d'Acremont, Abdellah Ammar, Haddou Jabour, Jean-Luc Auxietre

$\begin{array}{ll}\text { PII: } & \text { S0040-1951(16)30014-2 } \\ \begin{array}{l}\text { DOI: } \\ \text { Reference: }\end{array} & \begin{array}{l}\text { doi: } 10.1016 / \mathrm{j} . \text { tecto.2016.03.020 } \\ \text { TECTO 127012 }\end{array} \\ \text { To appear in: } & \text { Tectonophysics } \\ & \\ \begin{array}{l}\text { Received date: } \\ \text { Revised date: }\end{array} & \text { 17 December 2014 } \\ \text { Accepted date: } & \text { 14 March 2016 }\end{array}$

Please cite this article as: Do Couto, Damien, Gorini, Christian, Jolivet, Laurent, Lebret, Noëmie, Augier, Romain, Gumiaux, Charles, d'Acremont, Elia, Ammar, Abdellah, Jabour, Haddou, Auxietre, Jean-Luc, Tectonic and stratigraphic evolution of the Western Alboran Sea Basin in the last 25 Myrs, Tectonophysics (2016), doi: 10.1016/j.tecto.2016.03.020

This is a PDF file of an unedited manuscript that has been accepted for publication. As a service to our customers we are providing this early version of the manuscript. The manuscript will undergo copyediting, typesetting, and review of the resulting proof before it is published in its final form. Please note that during the production process errors may be discovered which could affect the content, and all legal disclaimers that apply to the journal pertain. 


\title{
Tectonic and stratigraphic evolution of the Western Alboran Sea Basin in the last 25 Myrs
}

\author{
Damien Do Couto ${ }^{1,2,3^{*}}$, Christian Gorini ${ }^{2}$, Laurent Jolivet ${ }^{4,5,6}$, Noëmie Lebret ${ }^{4,5,6}$, Romain \\ Augier $^{4,5,6}$, Charles Gumiaux ${ }^{4,5,6}$, Elia d'Acremont ${ }^{2}$, Abdellah Ammar ${ }^{7}$, Haddou Jabour ${ }^{8}$, Jean-Luc \\ Auxietre $^{3}$ \\ ${ }^{1}$ Earth and Environmental Sciences, University of Geneva, 1205 Geneve, Switzerland \\ ${ }^{2}$ UPMC Université Paris 6, UMR 7193, ISTEP, 75005, Paris, France \\ ${ }^{3}$ Total S.A., 2 Place De La Coupole, 92078 Paris La Défense Cedex, France \\ ${ }^{4}$ Université d’Orléans, ISTO, UMR 7327, 45071, Orléans, France \\ ${ }^{5}$ CNRS/INSU, ISTO, UMR 7327, 45071 Orléans, France \\ ${ }^{6}$ BRGM, ISTO, UMR 7327, BP 36009, 45060 Orléans, France \\ ${ }^{7}$ Département de Géologie, Université Mohammed V, Faculté des Sciences, avenue Ibn-Batouta, B. P. \\ 1014, Rabat, Maroc \\ ${ }^{8}$ ONHYM, 34 Avenue Al Fadila, Rabat, Morocco
}

Corresponding author: Damien Do Couto, Damien.docouto@unige.ch

Keywords: West Alboran Basin; seismic stratigraphy; sag basin; geodynamics; slab retreat

\section{Abstract}

The Western Alboran Basin (WAB) formation has always been the subject of debate and considered either as a back-arc or a forearc basin. Stratigraphic analyses of high-resolution 2D seismic profiles mostly located offshore Morocco, enabled us to clarify the tectonic and stratigraphic history of the WAB. The thick pre-rift sequence located beneath the Miocene basin is interpreted as the topmost Malaguide/Ghomaride complex composing the Alboran domain. The structural position of this unit compared with the HP-LT exhumed Alpujarride/Sebtide metamorphic basement, leads us to link the Early Miocene subsidence of the basin with an extensional detachment. Above the Early Miocene, a thick Serravallian sequence marked by siliciclastic deposits is nearly devoid of extensional structures. 
Its overall landward to basinward onlap geometry indicates that the WAB has behaved as a sag basin during most of its evolution from the Serravallian to the late Tortonian. Tectonic reconstructions in map view and in cross section further suggest that the basin has always represented a strongly subsiding topographic low without internal deformation that migrated westward together with the retreating slab. We propose that the subsidence of the WAB was controlled by the pull of the dipping subducting lithosphere hence explaining the considerable thickness $(10 \mathrm{~km})$ of the mostly undeformed sedimentary infill.

\section{Introduction}

Post-Eocene Mediterranean geodynamics is governed by the northward subduction of the African plate and coeval slab retreat causing the formation of back-arc basins together with extension and collapse of internal zones of orogens (Réhault et al., 1984; Malinverno and Ryan, 1986; Dewey, 1988; Royden, 1993; Wortel and Spakman, 2000; Jolivet and Faccenna, 2000; Faccenna et al., 2001) after a major change in the subduction regime during the Oligocene (Faccenna et al., 1997; Jolivet and Faccenna, 2000). The present-day complex geometry of these subduction zones results from progressive slab tearing and detachment (Carminati et al. 1998a, 1998b, Wortel and Spakman, 2000) associated with a complex 3D mantle convection pattern (Faccenna et al., 2004; Spakman and Wortel, 2004; Jolivet et al., 2009, 2013; Faccenna and Becker, 2010; Sternai et al., 2014).

In the western Mediterranean, several back-arc basins have opened since the Oligocene following the retreat of the Tethyan slabs: the Liguro-Provençal basin, Algerian basin, Alboran Sea and Tyrrhenian Sea (Fig. 1, Faccenna et al., 2001). Amongst these basins, the Alboran Sea basin remains one of the most controversial issues in western Mediterranean geodynamics. Several hypotheses have been proposed so far to explain its formation by extension in the internal zones of the Betics-Rif orocline: (1) extensional collapse of a thickened crust due to convective removal of the continental lithospheric mantle (Platt and Vissers, 1989; Platt et al., 2003a) or (2) a delamination process (Seber et al., 1996; Calvert et al., 2000) or (3) the westward retreat of the subduction zone (Royden, 1993; Lonergan and White, 1997; Gutscher et al., 2002). Several authors pointed to the relation linking the behavior of Mediterranean slabs in the upper mantle and the tectonic history recorded in the crust (Faccenna et al., 2004; Spakman and Wortel, 2004; Jolivet et al., 2006, 2008; Booth-Rea et al., 2007). In more detail, the stretching of the continental crust composing back-arc regions appears to follow the mantle stretching during slab retreat (Jolivet et al., 2009), suggesting that back-arc extension was partly driven from below (Sternai et al., 2014).

The Alboran domain represents the westernmost termination of the peri-Mediterranean Alpine belt orogeny. Its arcuate shape, delimited by the Betic and Rif fold-and-thrust belts, is the result of 
subduction, collision and slab migration processes that mainly occurred during the Miocene (Faccenna et al., 2004; Spakman and Wortel; 2004; Jolivet et al., 2008). During the Neogene, several sedimentary basins were formed on top of the Alboran metamorphic basement. The thickest and oldest sedimentary depocenter, the Western Alboran Basin (WAB; Fig. 2A), was created and developed coeval with the exhumation and denudation of its underlying metamorphic continental crust (Soto et al., 1996; Comas et al., 1999). Different views of the basin fill geometry over time led to a variety of tectonic scenarios for the WAB inception: a pull-apart mechanism in a regional strike-slip setting (Bourgois et al., 1992), a sag basin (Morley, 1992, 1993) or a half-graben asymmetric basin (Mauffret et al., 2007).

The aim of this paper is to re-assess the architectural evolution of the Western Alboran Basin in relation to major geodynamic events through a comprehensive seismic analysis of the most complete dataset of seismic profiles available in the area (Fig. 2B). We then correlate this new tectonostratigraphic framework of the WAB with the onshore stratigraphic sequence and tectonic data covering both southern Spain and northern Morocco, with a more specific view from the Moroccan margin. Our final objective is to propose a coherent geodynamic model for the formation and evolution of the WAB based on our observations but also on the vast amount of information available on the surroundings, especially regarding the tectonic and sedimentary history of the peri-Alboran sedimentary basins.

Following up on this new set of observations at the scale of the whole basin, we illustrate the tectonic evolution with a series of palaeogeographic reconstructions and discuss the possible causes of the rapid subsidence and weak deformation observed on the Morrocan margin. We show that the evolution of the WAB was first controlled by a regional extensional phase in the Early Miocene, followed by a period of quiet tectonics and intense sedimentation and rapid subsidence in the Middle Miocene. The Western Alboran Basin subsidence most likely migrated hundreds of kilometers westward without significant deformation above a retreating slab and its subsidence may be due to the persisting density anomaly of the underlying dipping slab.

\section{Geological settings and tectonic framework}

\subsection{Western Mediterranean geodynamic models and mantle structures}

The complexity of the Betic-Rif orogenic system led to different types of geodynamic reconstructions that are still debated today (Lonergan and White, 1997; Jolivet et al., 2009; Vergés and Fernàndez, 2012; Platt et al., 2013). Most propose subduction models involving slab roll-back, delamination, slab break-off or slab tearing (Royden, 1993; Lonergan and White, 1997; Gueguen et al., 1998; Calvert et al., 2000; Rosenbaum et al., 2002a; Faccenna et al., 2004; Spakman and Wortel, 
2004; Jolivet et al., 2006, 2008; Vergés and Fernàndez, 2012). In the past few years, based on tomographic imagery, the analysis of mantle seismic anisotropy and modeling, a rather consensual model has emerged of the presence of a E-SE dipping slab beneath the Gibraltar-Betics area and retreating westward (Wortel and Spakman, 2000; Spakman and Wortel, 2004; Levander et al., 2014; Thurner et al., 2014).

Tomographic studies revealed the presence of an arcuate, vertical high-velocity anomaly located beneath the western Alboran Sea and southern Spain (Gutscher et al., 2002; Faccenna et al., 2004; Spakman and Wortel, 2004; Bezada et al., 2013). This anomaly, which has been interpreted as a remnant of the Alpine Tethys slab, extends continuously from a depth of $50 \mathrm{~km}$ to a depth of more than $600 \mathrm{~km}$ (Bezada et al., 2013). It is curved below the Gibraltar Arc and is partially detached from the surface below the eastern Betics (Spakman and Wortel, 2004; Bezada et al., 2013).

The Alboran area is affected by a large amount of shallow to intermediate- depth seismicity (40-120 km; Gutscher et al., 2002; Buforn et al., 2004; Stich et al., 2006; Pedrera et al., 2011; RuizConstán et al., 2011; Mancilla et al., 2013) and rare deep earthquakes (>600 km; Buforn et al., 1997). The intermediate-depth seismicity is clustered along a $\sim \mathrm{N}-\mathrm{S}$ trend beneath the Western Alboran Basin (Fig. 3A). This seismicity is aligned along the subducting plate curvature at the depth where the subducting slab starts to sink vertically (Fig. 3A; Bezada et al., 2013) and where mantle stresses produce a down-dip extension in the external arc of the continental slab (Ruiz-Constán et al., 2011). It is worth noting that the Western Alboran Basin (e.g. the main sedimentary depocenter of the area) is located above the slab hinge (cross-sections in Fig. 3A).

\subsection{The Betic-Rif orogenic system in the Alpine belt}

The Betic-Rif system results from the continental collision between the Alboran domain and the former Iberian and African passive margin during the Miocene (García-Hernández et al., 1980; Platt et al., 2003a; Chalouan et al., 2006; Crespo-Blanc and Frizon de Lamotte, 2006). In reality, this widely accepted scheme might be more complex than originally thought, as a possible suture zone was recently described within the external Rif (Michard et al., 2014). Simultaneously, the Internal zones, also referred to as the Alboran domain, underwent an extension of their metamorphic basement (Platt and Vissers, 1989; García-Dueñas et al., 1992; Augier et al., 2005a, b). From the external toward the internal zones, the Betic-Rif realm is composed of several tectonic domains (Fig. 1, 2A): (a) two foreland basins, namely the Guadalquivir and the Gharb basins; (b) the External Zones of the Betics and Rif; (c) the Flysch Trough units; (d) the metamorphic complexes of the Internal Zones and (e) the Alboran Sea basins.

The former Iberian and African passive margins compose fold-and-thrust belts called the 
External Zones (Fig. 2A), following the Gibraltar Arc. Made up of Mesozoic and Cenozoic deposits, these units overthrust both the Iberian and Moroccan continental basements, during the late Eocene and Miocene, respectively (García-Hernández et al., 1980; Wildi, 1983; Berástegui et al., 1998; Frizon de Lamotte et al., 2004). Two foreland basins were formed during overthrusting of the External Zones, the Guadalquivir basin (north of the Betic Cordillera) and the Gharb basin (south of the Rif) (Fig. 1). Both basins display a rather similar Middle Miocene (Langhian) to Pliocene sequence (Flinch, 1994; Berástegui et al., 1998; Fernàndez et al., 1998; Vera, 2000; Chalouan et al., 2008). In the Gulf of Cadiz, a thick chaotic body observed in seismic reflection imaging and called the Imbricate Wedge (Iribarren et al., 2007) comprises a west-migrating thrust system correlated with two chaotic units in the Guadalquivir and Gharb basins (Maldonado et al., 1999; Iribarren et al., 2007).

The Flysch Trough units (or Flysch Complex) are structurally sandwiched between the External and Internal Zones (Fig. 1, 3). These deep siliclastics sediments are composed of four main units on both sides of the Strait of Gibraltar, and were mostly deposited from the upper Cretaceous to the lower Miocene (Didon et al., 1973; Guerrera et al., 1993).

The Internal Zones of the Betic and Rif orogenic belt, also referred to as the Alboran domain, are composed of three metamorphic complexes stacked during the Alpine orogeny. From bottom to top, the Internal Zones are composed of the Nevado-Filabride (NFC), the Alpujarride/Sebtide (ASC) and the Malaguide/Ghomaride (MGC) complexes (Fig. 2A; Torres-Roldán, 1979; Martínez-Martínez and Azañón, 1997; Michard et al., 2002). Located between the Malaguide/Ghomaride complex and the Flysch units, the Mesozoic-Paleogene Dorsale Calcaire represents the sedimentary cover of the inner Alboran domain (Chalouan and Michard, 2004; El Kadiri et al., 2006). Nevado-Filabride and Alpujarride/Sebtide complexes underwent a high-pressure (HP) and low-temperature (LT) metamorphism (Puga et al., 2000; López Sánchez-Vizcaíno et al., 2001; Martínez-Martínez et al., 2002a; Augier et al., 2005a). The age of the HP-LT event is not well established for either complex: (a) it extends from the Early Eocene (Monié and Chopin, 1991), Oligocene (Augier et al., 2005b) to as late as the Middle Miocene (López Sánchez-Vizcaíno et al., 2001; de Jong, 2003; Platt et al., 2006) for the Nevado-Filabride complex; (b) and from the Early Eocene to the Oligocene for the Alpujarride/Sebtide complex (Monié and Chopin, 1991; Platt et al., 2005; Michard et al., 2006). Today, the three Nevado-Filabride, Alpujarride/Sebtide and Malaguide/Ghomaride complexes are separated by crustal-scale extensional shear zones (García-Dueñas et al., 1992; Lonergan and Platt, 1995; Platt et al., 2005; Augier et al., 2005a). The exhumation of the Alpujarride/Sebtide complex occurred during the Early Miocene (22 to $18 \mathrm{Ma}$ ) in a N-S to NNE-SSW extensional setting (Monié et al., 1994; Crespo-Blanc et al., 1994; Crespo-Blanc, 1995; Kelley and Platt., 1999; Platt et al., 2005) while the exhumation of the Nevado-Filabride complex occurred from the Early to the late Miocene (20 to 9 Ma; de Jong, 1991; Monié and Chopin, 1991; Johnson et al. 1997; Augier et al., 2005b; Platt et al., 2005; Vázquez et al., 2011) through a $\sim \mathrm{E}-\mathrm{W}$ regional-scale extension (Jabaloy et al., 1992). 
Two large bodies of mantle peridotites were found both in Spain (Ronda) and in Morocco (Beni Bousera). These bodies were emplaced in the Alpujarride/Sebtide complex at around $22 \mathrm{Ma}$ (Esteban et al., 2011) through a basal crustal south-verging thrust (Hidas et al., 2013; Précigout et al., 2013).

\subsection{Peri-Alboran sedimentary basins}

From the Early Miocene onward, compressive deformation progressively propagated through the Betic and Rif External Zones (Crespo-Blanc and Frizon de Lamotte, 2006) while extension and erosion occurred in the Internal Zones. As a consequence, two main generations of sedimentary basins were formed. The first subsidence pulse took place early in the Aquitanian-Burdigalian up to Langhian time while the second occurred later during the Serravallian-Tortonian (Sanz de Galdeano and Vera, 1992; Vissers et al., 1995; Vera, 2000). The first generation of basins is currently highly tectonised and their initial geometry is difficult to reconstruct as their outcrops progressively disappear from the west to the east of the Betic Cordillera (Serrano et al., 2007). They are almost absent in the Internal Rif (Serrano et al., 2007). This first generation of sedimentary basins lies unconformably over the Malaguide-Alpujarride basement and is associated with E-W trending, generally top-to-the-N extensional structures (Crespo-Blanc et al., 1995; Serrano et al., 2007; Suades and Crespo-Blanc, 2013). The second generation of sedimentary basins formed from the Serravallian onward (Sanz de Galdeano and Vera, 1992; Vera, 2000; Rodríguez-Fernández et al., 2011), under a top-to-the-WSW extensional regime. These basins, also called intramontane basins, are mostly located in the southeastern Betics and are composed of a similar stratigraphic succession (Rodríguez-Fernández et al., 2011). Extensional structures were observed at the border of the basins or within the earlier deposits leading some authors to link their initiation with the latest exhumation stages of the NevadoFilábride complex (Crespo-Blanc, 1995; Meijninger and Vissers, 2006; Rodríguez-Fernández and Sanz de Galdeano, 2006; Augier et al., 2013; Do Couto et al., 2014b).

\subsection{Structure and stratigraphy of the Western Alboran Basin}

\subsubsection{Basin floor}

The crustal structure of the Alboran Sea shows an abrupt thinning, starting from the Betic and Rif Chains ( 45 km) toward the Alboran Sea ( 15-20 km) (Fig. 3.B; Fullea Urchulutegui et al., 2005; Thurner et al., 2014). The Alboran Sea basement is composed of metamorphic rocks similar to those found in the Internal zone of the Betic Cordillera (Sánchez-Gómez et al., 1999; Soto et al., 1999) intruded by many volcanic seamounts aged between 17 to 8 Ma (Comas et al., 1999; Duggen et al., 
2008). Radiometric ages of the Alpujarride-Sebtide basement drilled at the ODP Site 976 suggested exhumation in the Early Miocene, between 20 and 18 Ma (Kelley and Platt, 1999; Hurford et al., 1999). These ages of exhumation agree with the exhumation history of the Alpujarride-Sebtide metamorphic nappe, outcropping both in the Betics and Rif Chains, which progressively exhumed in a roughly N-S extensional setting (Monié et al., 1994; Crespo-Blanc et al., 1994; Crespo-Blanc, 1995; Platt et al., 2003b, 2005; Michard et al., 2006; Chalouan et al., 2008).

It is widely accepted that the Alboran Basin was concerned by extensional tectonics from the Early to the late Miocene followed by a contractional reorganization resulting from the convergence of the Eurasian and African plates (Comas et al., 1999). This late Miocene and still ongoing compression resulted in the inversion of the Alboran Ridge up to the Xauen Bank (Bourgois et al., 1992; Chalouan et al., 1997).

\subsubsection{Stratigraphy of the WAB}

The history of the Alboran Sea was mainly explored in the 1980s with the drilling of five commercial wells on both the Spanish and Moroccan upper slopes (Andalucia-A1 and G1, Alboran A1, El Jehba, Nador 1; Fig. 2A) accompanied by the acquisition of a dense grid of two-dimensional (2-D) multichannel seismic profiles $(>10,000 \mathrm{~km})$. Several studies presented the main results of these seismic surveys offshore Spain and Morocco (Bourgois et al., 1992; Comas et al., 1992; Mauffret et al., 1992; Morley, 1992, 1993; Chalouan et al., 1997; Booth-Rea et al., 2007). More recently, up to 3,000 km of high-resolution 2-D multichannel seismic profiles were acquired on the WAB (Fig. 2B). Part of this recent 2D seismic dataset was presented by Soto et al. (2010) who studied shale tectonics on the Spanish side of the Alboran Sea. Kuo et al. (2002), Mountfield et al. (2002), and Weinzapfel et al. (2003) reassessed and specified the hydrocarbon potential of the Alboran Sea arguing in favor of a Miocene petroleum system in this basin.

Several academic cruises (Willet, 1991; Maldonado et al., 1992; Watts et al., 1993), industrial seismic surveys (Bourgois et al., 1992; Comas et al., 1992; Morley, 1992; Chalouan et al., 1997), and analyses of boreholes (Jurado and Comas, 1992) revealed the overall Alboran Sea structure and infilling. Three main subbasins, called respectively the Western, Southern and Eastern Alboran Basins (WAB, SAB, EAB; Fig. 2A) rest on the metamorphic and volcanic basement. The most important sedimentary depocenter is located on the Western Alboran Basin (WAB) and its axis mimics the arcuate geometry of the orogenic arc (Soto et al., 1996; Iribarren et al., 2009). The sedimentary thickness of the WAB is estimated at between 10 to $12 \mathrm{~km}$ (Soto et al., 1996; Mauffret et al., 2007; Iribarren et al., 2009; Weinzapfel et al., 2003) and is mainly affected by shale tectonics (Soto et al., 2010) and associated mud volcanism (Pérez-Belzuz et al., 1997; Sautkin et al., 2003; Blinova et al., 2011; Somoza et al., 2012; Gennari et al., 2013). Three wells, called Alboran-A1, Andalucia-G1 and 
El Jebha, located on the Spanish and Moroccan shelves (Fig. 2A), enabled recovery of a stratigraphic column mainly composed of siliciclastic layers from the Lower Miocene to the Quaternary (Jurado and Comas, 1992; Morley, 1992; Chalouan et al., 1997). Previous studies provided a general chronostratigraphic framework of the sedimentary filling of this basin and defined up to six major seismic units (unit I to unit VI) (Fig. 4; Comas et al., 1992; Jurado and Comas, 1992; Comas et al., 1999, Soto et al., 2010, Hernández-Molina et al., 2011) separated by regional unconformities. From bottom to top:

- Unit VI (latest Aquitanian? - Burdigalian) is composed of clays with interbedded sandy intervals above a basal pebbly sandstone. This interval was drilled in the Alboran-A1 well and logging data suggested the occurrence of undercompacted shales. It consists of olistostromes containing polymictic rocks (olistoliths and rock breccia) embedded in an undercompacted shale matrix.

- Unit V (Langhian - Lower Serravallian) is separated into two sub-units: the lower subunit, $\mathrm{Vb}$, is made up of clays, interbedded silty to sandy clays, and a basal coarse-grained sandstone. Recorded in the Andalucia-G1 and Alboran-A1 wells, this unit displays typical features of undercompaction with abnormal pressures. The upper subunit, Va, consists of well-graded sand-siltclay turbidites and turbiditic muds interbedded with volcanogenic layers.

- Unit IV (Serravallian - Tortonian) consists of graded sand-silt-clay turbidites interbedded with a few volcanogenic layers.

- Unit III (Upper Tortonian) is composed of sandstone intervals, with claystones and silty clay beds, also corresponding to turbidite facies with some channel-like features.

- Unit II (Messinian) consists of marine sandy turbidites interbedded with carbonates, and volcaniclastics layers. The upper section is made of gypsum and thin anhydrite intervals linked to the Messinian Salinity Crisis deposits.

- Unit I (Pliocene - Quaternary) is represented by pelagic and hemipelagic marls and clays, muddy to sandy turbidites, and contouritic deposits.

The undercompacted shales in unit VI and sub-unit $\mathrm{Vb}$ are involved in the mud volcanic activity of the area (Sautkin et al., 2003; Gennari et al., 2013) and in the shale tectonics that affect the WAB (Chalouan et al., 1997; Soto et al., 2010).

\section{Datasets and methodology}

Within the study area, the seismic dataset comprises $10,000 \mathrm{~km}$ of vintage 2D seismic lines covering the entire WAB through the Gibraltar Arc (Fig. 2B). The mean seismic data coverage 
fluctuates between 5 and 7 seconds two-way travel time (TWTT) revealing a thick Neogene cover above the metamorphic basement even though the base of the sedimentary depocenter is barely perceptible in the deepest parts. An additional 2,500 km of 2D seismic lines acquired by Conoco in 2000 and 2001 (CAB survey) were used (courtesy of the ONHYM Morocco and the ICM-CSIC of Barcelona). This seismic dataset covers as deep as 12 seconds TWTT and makes it possible to investigate the deeper units in the WAB in more detail. All the seismic profiles, including the CAB surveys both offshore Spain and Morocco (orange lines in Figure 2B) are available in two-way travel time (TWTT). In addition, the $\mathrm{CAB}$ seismic lines located offshore Spain are also accessible in the depth domain (migrated by Conoco with stacked and root-mean square velocities inversion; blue lines in Figure 2B).

We conducted a detailed study of all $12,500 \mathrm{~km}$ of seismic data to characterize and define the seismic unit architecture of the Western Alboran Basin together with the geometry of their bounding surfaces (onlap, toplap, downlap and truncations) based on the seismic stratigraphic principles presented by Mitchum and Vail (1977), Van Wagoner et al. (1988) summarized in Catuneanu et al. (2009). The seismic stratigraphic analysis was performed on all the TWTT seismic profiles and jointly propagated on the depth migrated seismic lines of the $\mathrm{CAB}$ dataset offshore Spain by recognition of the seismic units (thanks to their respective facies and stratal terminations). The depth migrated CAB seismic lines were generated to match the geological interfaces encountered in the deep wells and to better represent the geometry of the basin fill. For this reason, and also to illustrate the complete seismic dataset, seismic profiles of the $\mathrm{CAB}$ dataset are displayed in the time domain offshore Morocco and in the depth domain offshore Spain.

Isochron maps of the main stratigraphic sequences were generated and converted into isochore and then into isopach maps using average seismic velocities calculated from the sonic log velocities recorded in the Andalucia-G1 and El Jebha wells (Chalouan et al., 1997; Soto et al., 2010). During this process, the depth migrated seismic profiles (offshore Spain) helped check the consistency of the calculated isopach. Isopach maps of the main stratigraphic sequences identified provide important information about the migration of depocenters and the deformation history of the WAB over time. The seismic units identified in the 2D seismic dataset were tied to the Andalucia-G1 and El Jebha wells (Figs. 4, 5, 6). Isopach maps were then computed for each seismic unit to identify growthrelated, thinning and subsidence thickening units in order to constrain the evolution of the basin over time.

Among all the foraminifers and calcareous nannoplankton species recognized in both wells, biostratigraphic markers (listed in the middle column in Figure 4) helped to reassess the ages of the formations according to Neogene standard zonations (Lourens, 2004; Raffi et al., 2006; Anthonissen and Ogg, 2012; Hilgen et al., 2012). The Pliocene in the Andalucia-G1 well is characterized by the 
basal occurrence of the Sphaeroidinellopsis acme zone and the first occurrence of G. margaritae from $860 \mathrm{~m}$ upward. The Messinian can be delineated by the co-occurrence of G. plesiotumida and G. miotumida (conomieza). The limit between the Tortonian and the Serravallian remains less clear, it was set after the last occurrence of G. praemenardii (at 1,934.8 m) and before the first occurrence of G. dehiscens and G. menardii cultrata (at 1,920 m). Likewise, the boundary between the Serravallian and the Langhian was set after the last occurrence of P. glomerosa (at 3,040 m) and before the first occurrence of G. mayeri and G. siakensis (at 3,020 m). The base of the well is marked by the occurrence of Praeorbulina sicana, which characterizes the late Burdigalian-Early Langhian (occurrence from 16.38 to $14.53 \mathrm{Ma}$; Anthonissen and Ogg, 2012).

In the El Jebha well, the Pliocene and Messinian biozones are respectively marked by the occurrence of G. margaritae and D. quinqueramus (Fig. 4). The co-occurrence of G. acostaensis, G. menardii and D. quinqueramus between 420.6 and 1,993.4 m identifies the Tortonian but the boundaries between the Langhian, Serravallian and Tortonian are not clear.

To place the formation and evolution of the $\mathrm{WAB}$ in the westernmost Mediterranean geodynamic context, we generated several paleogeographic maps at regional scale. These reconstructions were created from the paleokinematic reconstructions of Jolivet et al. (2006), which, in turn, are based on the kinematic parameters of Dewey et al. (1989) and concerning motion of large plates, on Rosenbaum et al. (2002b). Paleo-coastlines came from several different sources (Dercourt et al., 1993; Meulenkamp and Sissingh, 2003; Gibert et al., 2013) and were adapted based on our own observations (Do Couto et al., 2014a, b) in the knowledge that the more recent the reconstructed paleo-coastlines, the more accurate their contours.

\section{Seismic stratigraphy: results and interpretation}

\subsection{Seismic stratigraphic interpretation}

To define seismic units, we conducted seismic stratigraphic analysis of several recently acquired seismic profiles, beginning with the Spanish margin where the CAB01-125, devoid of any shale tectonic perturbation (Fig. 5), enables interpretation of up to 11 horizons (referred to as R1-R8, from the oldest to the youngest) that can be traced over long distances. In between, eight major seismic units (SU) are defined by their seismic facies, large-scale reflection configurations and their specific stratigraphic contacts with their lower and upper bounding surfaces. The boundaries that delimit the seismic units are marked by stratal terminations and sometimes by an acoustic impedance jump, either positive or negative depending on the acceleration or deceleration of the acoustic velocity. All horizons and seismic units in between were tied to the Andalucia-G1 and El Jebha wells, as shown in Figure 4. We now describe the seismic units from bottom to top. 


\subsubsection{SU1}

Description - The deepest seismic unit, SU1 (Fig. 5, 6), is characterized by a moderate to high amplitude, a discontinuous reflection package in the basin as well as minor chaotic internal reflections (Fig. 6). On the Spanish side, SU1 reflection packages onlap a high-amplitude reflector R1 (Fig. 5), defining the top of the acoustic basement. This unconformity can be traced all round the basin even if it is difficult to recognize in the deepest part because tectonic activity and mobile shale disturb the signal. Where it is visible, its upper bounding surface R2 is marked by erosional truncation of SU1 reflectors and onlap or baselap terminations of the younger sequences (Fig. 5, 7).

On the eastern Moroccan margin, SU1 is thick ( 2s TWTT) and is composed of two main subunits called SU1a and SU1b (Fig. 8). The lower bounding surface of SU1a is characterized by a high amplitude reflector that appears to be disrupted by several normal faults, whereas the top one corresponds to a major onlapping surface (Fig. 8). The upper subunit (SU1b), which is similar to that identified offshore Spain, is marked by moderate to high-amplitude and discontinuous reflectors with more chaotic reflections locally (Fig. 8). The lower subunit (SU1a) presents low to moderate amplitude reflectors together with chaotic internal reflections and is separated from SU1b by a high amplitude disrupted reflector. SU1a disappears toward the east and south of the WAB, and SU1b lies directly on the acoustic basement (Fig. 8, 9) as observed offshore Spain (Fig. 5, 7). Two SW-NE dip seismic lines display the wedge-shape configuration of the entire SU1 together with progressive thinning of SU1a toward the center of the basin (Fig. 10, 11). A close-up of the seismic attributes of SU1 on the Moroccan margin (CAB01-140 in Figure 12) shows that the base of subunit SU1b is relatively well marked by a high amplitude, red-to-blue couple of reflectors. To the south, SU1b is deformed by prominent thrusts (Fig. 8,9), probably rooted in the basement, and marking the frontal thrust of the Xauen Bank (Fig. 1). In addition, R1 reflector (top of the acoustic basement) appears discontinuous and deformed in the center of the WAB, suggesting a deformation phase and hence the basement (thick-skin deformation). The alignment and offset of the structures suggest the presence of a central transpressional zone that will be discussed later in conjunction with the basin fill geometry.

Interpretation - This seismic unit has never been drilled in the Alboran Sea. Chalouan et al. (1997) interpreted this tilted unit as belonging to the Middle Miocene, whereas Mauffret et al. (2007) interpreted it as belonging to the deepest Lower Miocene unit VI drilled offshore Malaga (e.g. Comas et al., 1999). Its age and significance thus remain questionable and will be addressed later on. The seismic facies of this unit is mainly composed of moderate to high amplitude reflectors that are strongly deformed on the northern Moroccan margin (Fig. 8), and evolve laterally to a lower amplitude and more chaotic facies (Fig. 10). In the deepest part of the basin, sub-unit SU1b is characterized by a cohesive package of high amplitude subparallel reflectors (Fig. 11). The acoustic facies is clearly of sedimentary origin in this profile and could reflect the presence of carbonate beds or siliciclastic deposits like condensed turbiditic layers. The tilted geometry of SU1 unit together with 
its onlapping upper bounding surface suggest a deposition preceding the main subsidence and rifting phases of the Western Alboran Basin. In the southern part of the WAB, SU1 is tilted all along the margin and can be traced landward (Fig. 8).

\subsubsection{SU2}

Description - SU2 is separated from SU1 by a high-amplitude low-frequency continuous reflector R2 (Fig. 5). SU2 is dominated by moderate to high-amplitude and low-frequency semicontinuous reflection packages that are extensively deformed. The stratigraphic contacts of this unit are characterized by onlap terminations on the acoustic basement toward the center of the basin, and by baselap termination on R2 reflector (Fig. 5, 7, 11). SU2 is relatively thin, never exceeding $300 \mathrm{~m}$ on the depth migrated seismic line and its spatial distribution is limited on the northern sideof the WAB. SU2 has not been observed offshore Morocco. As can be seen in Figure 12 (CAB01-123 and CAB01-125), its internal seismic attributes are relatively homogeneous and its underlying boundary with SU1 is well marked by a high amplitude (red-to-blue couple) reflector. The spatial distribution of SU2 is difficult to asses across the WAB. It can easily be traced in places where mud volcanic activity does not disturb the acoustic signal (Fig. 5, 7) but offshore Morocco, its distribution is more confusing. This statement is of importance for the discussion regarding the mud volcano root at depth.

Interpretation - This seismic unit has not been reached by drilling in the Western Alboran Basin. It seismic facies could mark the presence of carbonate beds or even coarse-grained siliciclastic deposits. It is the first sedimentary record of the basin overlying the "pre-rift" sequence SU1, and could thus be linked to the Lower Miocene deep marine deposits identified in the Alboran-A1 borehole, defined as an olistostromic unit (Jurado and Comas, 1992; Comas et al., 1999) made up of shales, slightly calcareous siltstone and sandstones. Onshore, the oldest post-nappe deposits are composed of late Oligocene-Aquitanian and Burdigalian formations called Ciudad Granada-Fnideq and Viñuela-Sidi Abdeslam, respectively (Serrano et al., 2007; Hlila et al., 2008). These formations consist of proximal marine breccias and conglomerates passing to deep marine siliciclastics (marlstone, sandstone or pelagic shales), the Viñuela-Sidi Abdeslam formations being more distal. The contact between these two units becomes nearly conformable in the central parts of the depocenter (Serrano et al., 2007; Hlila et al., 2008) making their respective identification on seismic lines difficult (Martínez del Olmo and Comas, 2008). SU2 could represent such Early Miocene deposits in the deepest part of the basin and could consequently be attributed to the late Aquitanian-Burdigalian. However, this suggestion should be interpreted with caution, as the only microfossil partially marking the late Burdigalian (e.g. Praeorbulina sicana, occurrence from 16.38 to $14.53 \mathrm{Ma}$; Anthonissen and Ogg, 2012) retrieved in the bottom $87 \mathrm{~m}$ of the Andalucia-G1 well belongs to the upper seismic unit SU3. 


\subsubsection{SU3}

Description - The seismic unit SU3 is bounded below by a moderate to high amplitude and continuous reflector R3 (Fig. 5, 11). SU3 is composed of moderate amplitude and low frequency discontinuous reflections packages. Its seismic facies is frequently marked by chaotic reflections with acoustic diffractions patterns, and also by the occurrence of low frequency and high amplitude segments (Fig. 7). Baselap terminations are visible locally on the R3 reflector. SU3 lies unconformably over SU2 or SU1 units (Fig. 5, 7, 8, 11). SU3 is marked by local variations in thickness: offshore Spain, its thickness can reach up to 2,000 $\mathrm{m}$ (based on an internal seismic velocity of 2,500 m/s); offshore Morocco, SU3 is thinner and reaches only $500 \mathrm{~ms}$ TWTT in the central part of the WAB. SU3 pinches out against SU1 or the basement (Fig. 10, 11).

Interpretation - SU3, which is tied to the Andalucia-G1 borehole, corresponds to the section located between 3,090 and 3,716 mbsf, which is mostly composed of greenish to reddish shales above a basal marine conglomerate (Fig. 4). The interval between 3,640 and 3,140 m.b.s.f. has a microfauna rich in reworked Cretaceous species and only rare Miocene species (Fig. 4). Along with the chaotic seismic facies including contourned preserved bedding (SU3 in Fig. 5), this configuration is in favor of gravity-flow deposits. In the El Jebha borehole, part of the lower shaly sandstone interval could belong to this unit (Fig. 4, 6). Logging data show the occurrence of undercompacted shales within the unit dated from the Langhian based on its foraminiferal content (Fig. 4; Soto et al., 2010). At the base of the Andalucia-G1 well, the occurrence of Praeorbulina sicana characterizing the late BurdigalianEarly Langhian (occurrence from 16.38 to $14.53 \mathrm{Ma}$; Anthonissen and Ogg, 2012) suggests a possible older age of the lower part of the unit (industry well report). Shale and mud intrusions, causing mud volcanism in the WAB (Sautkin et al., 2003; Somoza et al., 2012; Gennari et al., 2013), appear to be mostly rooted in this deep unit SU3 according to the seismic images (Fig. 9, 10, 12). This observation is in agreement with micro-paleontological identifications made in several mud volcanoes showing the occurrence of Early to Middle Miocene foraminifers in the shaly matrix of mud breccias (Sautkin et al., 2003; Gennari et al., 2013). The occurrence of mud at depth obstructs and deforms the acoustic signal making the deep roots of the mud pipes difficult to assess. It is thus reasonable to assume that the mud volcanoes of the WAB are at least rooted in the deep SU2 and SU3.

\subsubsection{SU4}

Description - SU4 unconformably lies on SU1 to SU3 units showing onlap geometries toward the edge of the basin (Fig. 5, 6, 7, 8). SU4 is characterized by two distinct seismic facies: one consists of variable amplitude, laterally continuous, parallel reflectors, whereas the second consists of 
lower amplitude reflectors locally displaying transparent reflection. Chaotic reflections were also identified at the base of the SU4 mega sequence (Fig. 8). The internal unconformities enabled the identification of three sub-units from the bottom to the top SU4a to SU4c:

- Sub-unit SU4a is characterized by low to moderate amplitude, moderate frequency continuous sheeted reflectors (Fig. 5, 7). Locally, the seismic facies evolve to a low frequency reflection package presenting disrupted reflectors (East of CAB-102 seismic line; Fig. 7).

- Sub-unit SU4b is characterized by low to moderate amplitude, continuous sheeted reflectors (Fig. 5, 6, 7) displaying an erosive basal surface (Fig. 8). The amplitude and frequency of the reflection package increase from the northern to the southern side of the WAB (Fig. 5, 9, 10).

- Sub-unit SU4c presents a similar seismic facies signature to subunit SU4a composed of low to moderate amplitude, moderate frequency continuous sheeted reflectors (Fig. 5, 7). Its basal reflector is marked by the truncated reflectors of the overlying subunit SU4b, and by onlap terminations of SU4c (Fig. 5, 8, 9, 10).

The overall geometry of SU4 shows basinward thickening that is not affected by the NW-SE transpressional zone crossing the basin at its center (Fig. 10, 11). However, normal faults on the Moroccan upper slope (western side of CAB01-132 and 140, Fig. 10) appear to have controlled part of the sedimentation, as basinward thickening is observed in sub-unit SU4a. These normal faults could have been active during the deposition of SU3 and SU4 (Fig. 10) and reactivated later. They are rooted at the interface of SU1a and SU1b (Fig. 10, 11).

Interpretation - SU4, tied to the Andalucia-G1 and El Jebha boreholes, is mostly composed of sandstones, conglomerates, shaly sandstones and clayey layers dated from the Serravallian (Fig. 4, 5 , 6). In the middle of the Serravallian section, $\sim 240 \mathrm{~m}$ of volcanoclastic layers composed of sandstones and shales alternating with acidic volcanic layers could represent the highest amplitude reflectors visible in the SU4b sub-unit (Fig. 5,7). The seismic facies of subunits SU4a and SU4c marks the deposition of prograding clastics along the margin (fan delta) and siliciclastic sheeted turbidites in the deepest part of the basin interbedded with hemipelagic deposits. Landward-stepping stacking patterns of sub-units SU4a to SU4c shows an overall net increase in the accommodation space during deposition of the SU4 mega-sequence. A significant change can be observed at the base of SU4c (Fig. 11). Although no significant channel features were observed in our seismic data, internal reflections suggest the presence of sheeted turbidites and compensating lobes geometries. Hence, Serravallian depositional facies architecture reflects episodic subsidence patterns, with basincentered facies tracts (turbidites). 


\subsubsection{SU5}

Description - unit SU5, unconformably overlying SU4 is composed of two sub-units, SU5a and SU5b, separated by a high amplitude unconformable reflector R5b on which baselap terminations were observed (Fig. 5). SU5 onlaps on SU4 and basement units (Fig. 5, 8). Internal reflections of subunits SU5a and SU5b are characterized by low to moderate amplitude, moderate frequency continuous sheeted reflectors (Fig. 5). The internal reflection pattern of SU5b resembles that of SU4 but with a higher frequency in its upper part (Fig. 7). The geometry of SU5 shows a basinward thickening where the acoustic imagery is disturbed by the central transpressional zone (Fig. 10, 11) but no major offset is observed.

Interpretation - SU5 is composed of similar materials to those of SU4. In the Andalucia-G1 and El Jebha boreholes, SU5 is composed of fine-grained to coarse-grained sandstones together with shaly sandstones, marls and shales dated to the Tortonian (Fig. 4). At that time, the basin underwent deep-water hemipelagic deposition of shales intercalated with turbiditic sheets. Seaward- to landwardstepping stacking patterns of SU5a and SU5b record the continued increase in accommodation space initiated during SU4 mega-sequence deposition. The arcuate central Alboran topographic high is buried by the siliciclastic flux from the top of the SU4c (late Serravallian) as revealed by seismic interpretation and confirmed by the results of drilling at the ODP 976 site (Comas et al., 1999).

\subsubsection{SU6}

Description - the SU6 unit presents mainly parallel to sub-parallel reflections (Fig. 5), characterized by moderate to low amplitude, low to moderate frequency reflectors above a conspicuous unconformity marked by a high-angle onlap on SU5 and the basement (Fig. 5, 8). This unit thickens toward the center of the basin to reach $1.3 \mathrm{~s}$ TWTT (Fig. 9, 10, 11). In the eastern part of the WAB, SU6 is made up of the superposition of three successive packages of low to high amplitude continuous reflectors (Fig. 9), pinching out towards the edge of the basin (Fig. 11). SU6 is affected by minor normal faulting on the Moroccan upper slope (Fig. 10) but in Figures 9 and 10, it is quite clear that the transpressional fault zone, marked by the mud volcanism perturbations on the acoustic signal, was active at that period.

Interpretation - SU6 has been drilled both in Andalucia-G1 and El Jebha boreholes, showing that it comprises sandstone interlayered with marl and clay beds from the Upper Tortonian- Messinian (Fig. 4). These layers have been interpreted as thin turbiditic deposits interlayered within hemipelagic sediments (Jurado and Comas, 1992). SU6 corresponds to the Unit III described by Jurado and Comas (1992), and lasted from the Upper Tortonian to the lowermost Messinian (synthesis in Comas et al., 1999). According to previous studies, the basal unconformity of this unit marks the compressive 
inversion of the entire Alboran Sea due to the Africa-Europe convergence. The basin-wide unconformity R6 is linked to the well-known contractive reorganization of the basin, starting around 8 Ma (Comas et al., 1999; Do Couto et al., 2014b). Toward the edges of the basin, progressive onlap shifts onto the basement suggest the occurrence of a tectonic event preceding SU6 deposition. R6 unconformity is characterized by chaotic reflections interpreted as a basal mass transport event probably related to a major change in tectonic activity at this time.

\subsubsection{SU7}

Description - The upper bounding surface of SU6 displays a large number of truncations and is locally covered by a relatively thin seismic unit with a small number of low to moderate amplitude chaotic reflectors (Fig. 7). At the base of the unit, high amplitude reflectors pinch out toward the Spanish margin. At the scale of the basin, this unit SU7 is thin, rarely exceeding 350 ms TWTT.

Interpretation -the Andalucia-G1 well drilled in SU7 comprises two sub-units with - from bottom to top - a volcanoclastic series made up of intercalated clays and basaltic layers under marine sandstones interbedded with finely laminated beds and shallow carbonate, with some gypsum and thin anhydrite intervals (Jurado and Comas, 1992). SU7 corresponds to Unit II described by Jurado and Comas (1992). The chaotic facies have been interpreted as mass transport deposits (Martínez del Olmo and Comas, 2008) linked to the sea level drop during the Messinian Salinity Crisis in the Mediterranean Sea.

\subsubsection{SU8}

Description -Horizon R8 (Fig. 5) bounding SU8 has a complex erosional surface. This unit is composed of low amplitude and high frequency sub-parallel reflectors evolving upward to high amplitude prograding, mound shaped and sub-parallel reflectors (Fig. 5, 7, 8, 9). Within the unit, internal erosive surfaces separate the lower low amplitude reflection package from the higher amplitude upper one (Fig. 9).

Interpretation -SU8, identified as Unit I in Jurado and Comas (1992), consists of pelagic to hemipelagic marls and clays, interlayered with sandy turbidites (Alonso et al., 1999) dated from the Pliocene and Quaternary. The basal erosional surface marks the imprints of the Messinian Salinity Crisis in the Alboran Sea (Estrada et al., 2011). Where erosion related to the Messinian Salinity Crisis is high, the Pliocene-Quaternary SU8 overlies older Tortonian to Serravallian deposits (Fig. 5, 8). In the Alboran Sea, a large number of contourite systems were caused by currents that affected the Mediterranean during the Pliocene and Quaternary (Palomino et al., 2011; Somoza et al., 2012). 


\subsection{Isopach mapping}

Based on our seismic interpretation, isochore maps were generated for each seismic unit and were depth-converted using mean interval velocities derived from the Andalucia-G1 and El Jebha industrial boreholes. The mean velocities used to calculate the different isopach maps are rounded values applied to outline the velocity trend observed in the wells.

The depth to basement map (Fig. 13A) was computed from the commercial 2D seismic dataset presented in Fig 2B, together with hundreds of academic seismic datasets, and represents the morphology of the metamorphic basement beneath the basin infill. The deepest depression reaches $8 \mathrm{~s}$ TWTT offshore Morocco and no more than $7 \mathrm{~s}$ offshore Spain. This is in agreement with previous estimates (Soto et al., 1996; Mauffret et al., 2007; Iribarren et al., 2009; Soto et al., 2010). All tectonic structures identified on seismic profiles show the effect of the inversion on the Alboran Sea basement. Numerous faults have been mapped throughout the Xauen Bank, showing reverse offset, or at least transpressional movement, considering the small vertical offset (Fig. 9) and the presence of several folded structures (Chalouan et al., 1997; Ammar et al., 2007). From the Alboran Ridge to the Xauen Bank, all faults and structures tend to parallel the Moroccan coast (Fig. 13A). A sinistral strike-slip component is likely to have occurred beneath the Xauen Bank to accommodate the northward African plate convergence, as suggested by Chalouan et al. (1997). The basin floor reflector R1 is disrupted by several faults with relatively low vertical displacement across the sedimentary pile (Fig. 10, 11). The alignment of these structures from south to north and their relatively steep pattern suggest the development of a wide NW-SE oriented transpressional fault zone. Given the associated mud volcanism, activity appears to be recent (Fig. 10, 11).

The isopach map of the pre-rift unit SU1 reveals that its thickest series are mostly concentrated along a NW-SE sedimentary package located on the western slope of the basement (Fig. 13B). On the Spanish side, two smaller packages reaching $2 \mathrm{~s}$ TWTT in thickness can be distinguished. The overall distribution of this unit is constrained on the Morrocan side of the WAB, where the compressive to transpressive deformation of the basin does not affect the thickness of the unit, which thus seems younger.

The main depocenter of the syn-rift seismic units of the Western Alboran Basin (SU2 and SU3), dated from the late Aquitanian-Burdigalian to the Langhian, is located along a roughly WSWENE trough parallel to the Spanish coastline (Fig. 13C). Its thickness can reach $2 \mathrm{~s}$ TWTT (Fig. 7, 13C) but on the southern side of the basin, never exceeds 700 ms TWTT. It should be noted that the seismic units SU2 and SU3 are grouped together because (1) they most probably mark the Early Miocene period (even if the SU2 unit has not been drilled) and (2) the spatial distribution of the SU2 
unit is rather limited offshore Spain, and thus appears to mark a more local sub-unit. In the central part of the WAB, the thickness rarely reaches $1 \mathrm{~s}$ TWTT, and generally does not exceed 500 to $750 \mathrm{~ms}$ TWTT. The involvement of undercompacted shales in the mud volcanism, together with the strong tectonic imprints in the southern WAB, render precise observations of the complete distribution of these units impossible.

The Serravallian (SU4) isopach map revealed significant reorganization of the depocenter with an acceleration of subsidence: a thick depocenter mimics the Gibraltar orogenic arc (Fig. 13D). Even with a large area of poorly imaged reflections where uncertainties remain in the seismic correlation (due to perturbations of mud/shale volcanism) in front of the Strait of Gibraltar, the thickness of these turbiditic deposits is similar over the whole basin, with a maximum thickness of about $2 \mathrm{~s}$ TWTT. A southeastward shift in the location of the Lower Tortonian (SU5) depocenter is observed with more than $1 \mathrm{~s}$ TWTT of sediments in the central part of the basin and a decrease in thickness to less than $750 \mathrm{~ms}$ in its northern part (Fig. 13E). The Upper Tortonian unit (SU6) reveals similar trends to those of the Lower Tortonian unit (SU5), with a maximum thickness of 1 to $1.25 \mathrm{~s}$ TWTT in the central part of the basin. This northward shift of the depocenter is linked to the regional compressive deformation that started at that time: the thickest depocenter is located at the front of distal thrusts (Fig. 11, 13F) while the Xauen Bank is folded and delineates E-W oriented synclines (Fig. 13F). Offshore Spain, the Upper Tortonian is reduced to $750 \mathrm{~ms}$ TWTT. The Pliocene to Quaternary isopach map presents the main depocenter that is still active as the western Ceuta drift, made of contouritic deposits and exceeding $1.5 \mathrm{~s}$ TWTT (Fig. 13G).

\section{Discussion of the seismic interpretation}

\subsection{Age and significance of the pre-rift sequence $S U 1$}

Over the years and with the improvement in seismic acquisition and treatment, SU1 has been interpreted in different ways, e.g. as belonging to the basement (Morley, 1993), as defining a Middle Miocene unit (Chalouan et al., 1997) or as representing the late Oligocene-Early Miocene older postnappe sediments (Mauffret et al., 2007). These interpretations were based on the strong chaotic facies imaged on old seismic profiles. The recent $2 \mathrm{D}$ seismic dataset presented here makes it possible to refine its significance and age.

The SU1 sequence lies on the acoustic basement over a high-amplitude continuous to semicontinuous reflector R1 (Fig. 8, 10, 11, 12). In the northern Moroccan margin, its seismic facies, composed of moderate to high amplitude chaotic reflections, contains sigmoidal internal reflections. The flattening of the CAB01-116 seismic line at the top of the Serravallian unit (SU4) displays the paleo-topography of SU1 during the deposition of Langhian to Serravallian deposits (Fig. 14). The 
orientation and shape of these sigmoidal reflections within the SU1b unit reflect a strong chaotic internal deformation. Offshore Spain, the Early Miocene olistostromic unit contains a similar seismic facies and structural characteristics (Martínez del Olmo and Comas, 2008). In the central Moroccan margin, the internal chaotic facies tends to disappear and SU1 is affected by landward normal faulting that affects the series up to the Serravallian (CAB01-132; Fig. 14). Langhian (SU3) and Serravallian (SU4) deposits onlap the SU1 unit, suggesting that the internal structuration of SU1 took place before the infill of the WAB (Fig. 14). Onlapping geometries can be observed all along the Morrocan margin, and the angular unconformity increases southward (Fig. 11, 14).

The high amplitude, continuous reflectors developed in the SU1b sub-unit (CAB01-140; Fig. $11,14)$ do not support the hypothesis of an olistostromic unit made of an extensive shaly matrix including heterometric and polymictic blocks. However, its seismic facies rather suggest the presence of carbonated beds or siliciclastics deposits like condensed turbiditic layers (Fig. 11). Unlike the Early Miocene sequence offshore Spain (Martínez del Olmo and Comas, 2008), the seismic reflections of the SU1 unit are higher in amplitude, and the isopach map shows that the thickest part of the unit does not fill the main depression but lies on the lower Moroccan slope (Fig. 13B). Based on a mean interval velocity of between $2,500 \mathrm{~m} / \mathrm{s}$ or $3,000 \mathrm{~m} / \mathrm{s}$ for the SU1 (depending on its lithology), the average thickness of SU1 can be estimated at 2 to $3 \mathrm{~km}$ (Fig. 14). The thickness of the late Oligocene-Early Miocene post-nappe deposits (Fnideq and Sidi Abdeslam formations: Serrano et al., 2007) recognized onshore never exceed $500 \mathrm{~m}$ (Zaghloul et al., 2003; Hlila et al., 2008), which does not seem to be sufficient to represent the SU1 sequence.

The SU1 unit is intercalated between the acoustic metamorphic basement and the Miocene series, resting as a tilted unit on the Moroccan margin. Its seismic facies, its thickness, the lack of extensional tectonics, do not support an olistostromic origin of SU1 in the late Oligocene-Early Miocene. We thus propose that the SU1 sequence represents a pre-rift unit on which the late Oligocene-Early Miocene formations transgress and, according to the geology of the Rif, two formations made of sediments are intercalated between the metamorphic basement and the Miocene series, 1) the Ghomaride unit (Feinberg et al. 1990; Durand-Delga et al., 1993; Zaghloul et al., 2003; Hlila et al., 2008) and 2) the backthrusted Maghrebian flysch klippe (see synthesis in Chalouan et al., 2008). As the latter is unlikely to reach the extension and thickness of SU1 (given the limited shape of the Maghrebian flysch klippe onshore), we opt for the Ghomaride complex. The Ghomaride unit is the topmost nappe composing the Alboran domain and mainly consist of slightly metamorphic Paleozoic successions (Chalouan, 1986) covered by Mesozoic-Cenozoic sedimentary successions. Mesozoic series are made of Triassic reddish sandstones and conglomerates, Liassic limestones and reddish silts and late Eocene Nummulitic limestones and calcareous conglomerates (Chalouan and Michard, 1990; Maaté et al., 2000; El Kadiri et al., 2006; Martín-Martín et al., 2006). The Ghomaride unit is separated from the Alpujarride-Sebtide by an extensional detachment (Chalouan and Michard, 1990). Its 
thickness varies and can reach 3 to $5 \mathrm{~km}$ (Chalouan and Michard 1990), which is the mean estimated thickness of SU1 offshore (Fig. 13B). The internal chaotic facies observed on the northern Moroccan margin (CAB01-116 seismic line; Fig. 14), suggest that part of the deformation accompanying the Ghomaride emplacement results from gravity-driven tectonics. This observation is in agreement with the Ghomaride origin of clastics of the Ciudad Granada-Fnideq and the Viñuela-Sidi Abdeslam formations (Durand-Delga et al., 1993; Serrano et al., 2007; Hlila et al., 2008).

\subsection{Tectono-stratigraphic history of the Western Alboran Basin}

\subsubsection{Mode of extension}

Contrary to the Spanish margin where extension occurred during the Early to Middle Miocene (Martínez del Olmo and Comas, 2008; Soto et al., 2010), the lack of a coeval extensional structure is surprising along the Moroccan margin. It is even more surprising that the seismic profiles interpreted on the Moroccan margin are SW-NE oriented, i.e. more or less in the same direction as the welldocumented extensional regime that lasted from the Middle to the Upper Miocene (Jabaloy et al., 1992; Martinez-Martinez and Azañon, 1997; Martínez-Martínez et al., 2002a, 2002b). Indeed, with respect to the pre-rift unit SU1 and the metamorphic basement, the stratigraphic relation of the Miocene basin fill does not display much normal faulting. The Miocene basin fill (from SU2 to SU7) onlaps its margins (Fig. 14, 15) and the contacts between sediments and pre-basin units are mostly stratigraphic. The geometry is essentially that of a sag basin, at least after the Serravallian where the stratal terminations show onlap geometries on both sides of the basin, even looking parallel to the direction of extension, with relatively homogeneous subsidence. This observation contradicts previous tectonic models of the WAB formation that invoked steep extensional faulting, or a strike-slip tectonic context (Bourgois et al., 1992; Mauffret et al., 2007). Consequently, the mode of extension at the origin of the Early Miocene initial subsidence, and post-thinning subsidence must be sought in other processes.

In the Early Miocene, when sedimentary deposition started in the Western Alboran Basin, the Alpujarride-Sebtide metamorphic basement of the Alboran domain experienced a progressive exhumation marked by a fast cooling path from $\sim 400{ }^{\circ} \mathrm{C}$ at $18-20$ Ma (Monié et al., 1994, Platt et al., 2003), to $\sim 100{ }^{\circ} \mathrm{C}$ at 17-16 Ma (Johnson et al., 1997; Platt et al., 2005; Vázquez et al., 2011). The coeval crustal extension resulted in the exhumation of high-pressure rocks and the thinning of the crust accompanied by low-angle brittle normal faults (Crespo-Blanc, 1995). The contact between the Alpujarride-Sebtide and the Ghomaride nappes has been documented as an extensional shear-zone (or detachment) (García-Dueñas et al., 1992; Lonergan and Platt, 1995; Crespo-Blanc, 1995; Platt et al., 2005; Augier et al., 2005a), which, during the late Oligocene-Early Miocene, acted through a N-S to NNE-SSW stretching direction (22 to $18 \mathrm{Ma}$ ) (Monié et al., 1994; Crespo-Blanc et al., 1994; Crespo- 
Blanc, 1995; Platt and Whitehouse, 1999; Hurford et al., 1999; Platt et al., 2005). The continuous basal contact of SU1 observed on the Moroccan margin (i.e. the top of acoustic basement) could represent such a detachment which today is tilted and sealed by the late Aquitanian-Burdigalian to Langhian SU2 and SU3 (Fig. 10, 11). Offshore Spain, the contact separating the Miocene series and the metamorphic Alpujarride-Sebtide basement has been interpreted as a detachment ramp (Martínez del Olmo and Comas, 2008; Soto et al., 2010). Moreover, a long history of extensional growth faults that accompanied the basin tilting and subsidence in the Early-Middle Miocene has been documented (Soto et al., 2010; Giraldo and Hermoza, 2013). Offshore Morocco, the base of the Ghomaride unit (SU1) has also been said to act as a detachment fault during the late Oligocene-Early Miocene and the exhumation of the Alpujarride-Sebtide complex (Chalouan et al., 1995), but the following extensional tectonics remain unclear. In this area, in contrast to the Spanish margin, extensional structures such as normal faults strike mostly parallel to the coastline (Fig. 13) and do not display a major offset (Fig. 10, 11) or gravity-driven tectonics. In the western part of the WAB, the contact separating the Burdigalian-Langhian (SU3) from the Ghomaride unit (SU1) does not display extensional structures resembling those visible offshore Spain (rollovers and listric faults) (Martínez del Olmo and Comas, 2008; Soto et al., 2010). However, south of the Xauen Bank, Chalouan et al. (1997) interpreted divergent onlap geometry over the acoustic basement highlighted by the Ghomaride unit (SU1; Fig. 8), and suggested a similar extensional detachment process to that described on the Spanish margin (Soto et al., 2010).

Placed in a wider context, these observations of seismic profiles illustrate probably strong control of extensional detachments in the early architecture of the Western Alboran Basin. It appears to be difficult, if not impossible, to reconstruct the dimension, and the evolution of such extensional detachment below the basin over time because of the complex following tectonic history. However, all observations and previous studies conducted in the Betic-Rif ranges show that the kinematics of the extension at that period is marked by a N-S regional penetrative extensional event (Crespo-Blanc et al., 1994; Crespo-Blanc, 1995; Platt et al., 2005). In that case, the lowermost SU2 and SU3 seismic units made up of shales would have been deposited as syn-kinematic sediments. The present-day geometries of the SU2 and SU3 seismic units show that most of the Early Miocene sediments are concentrated in a WSW-ENE trough more or less parallel to the Spanish coastline (Fig. 13C). Nevertheless, it has been shown that these sediments are largely involved in the extensional deformation on the Spanish margin and associated shale tectonism (Soto et al., 2010) and it would be hazardous to conclude from its present-day distribution in the basin.

\subsubsection{Tectonic and stratigraphic scenario}

The undercompaction of shales in the Burdigalian-Langhian series (Jurado and Comas, 1992; 
Soto et al., 2010), the lack of late Oligocene-Aquitanian sediments (Martínez del Olmo and Comas, 2008) or the P-T-t paths of the basement units (synthesis in Platt et al., 2013) are different arguments used by authors to suggest rapid subsidence at basin initiation in the Western Alboran Basin. Such a subsidence has been tentatively explained by strike-slip tectonics and associated pull-apart mechanisms (Bourgois et al., 1992), by thermal cooling of the Alboran Sea basement forming a sag basin (Morley, 1992, 1993) or by a half-graben basin (Mauffret et al., 2007). Our detailed seismic interpretation in a more regional context compared with field data, leads us to propose an alternative scenario.

The newly identified pre-rift sequence SU1, resting as a tilted unit upon which the Miocene series onlap, and interpreted as the Ghomaride unit, leads us to interpret the primary subsidence pulse of the Western Alboran Basin as the result of an extensional detachment, probably partly rooted in the Ghomaride/Sebtide interface (Fig. 15). Such a tectonic context has been documented onshore in the Early to Middle Miocene (Suades and Crespo-Blanc, 2013) and explains the rapid subsidence in the basin together with the tilting of the SU1 unit visible on the seismic lines (Fig. 15). The onlap geometry of Early Miocene deposits on the Ghomaride (Fig. 15) or Alpujarride-Sebtide basement (Martínez del Olmo and Comas, 2008) at the edge of the WAB suggests that the primary subsidence phase probably occurred in a subaerial environment, creating the accommodation space required for marine sedimentation. In the Betic and Rif belts, petrographic and sedimentological studies showed that the main clastic source of the late Aquitanian-Early Miocene deposits (our seismic units SU2 and SU3) was erosion of the Malaguide-Ghomaride units (Durand-Delga et al., 1993; Zaghloul et al., 2003; Serrano et al., 2007; Hlila et al., 2008). Figure 15 explains how most of the Ghomaride unit could have been eroded on the Moroccan side ("hanging wall"), and could have been preserved in the deep basin due to the tilting of the margin along a low angle detachment leading to the rapid exhumation of the Alpujarride-Sebtide units (Fig. 18; cross sections a and b).

Paleontological studies of mud volcanoes revealed the presence of extruded pre-Langhian foraminifers (Sautkin et al., 2003; Gennari et al., 2013) suggesting that the main mud source is rooted in the late Aquitanian-Burdigalian olistostromic unit in the entire WAB (our seismic units SU2 and possibly the base of SU3). This olistostromic unit, which is well developed in the northern branch of the WAB (Malaga basin; Comas et al., 1992), was correlated with seismic unit SU2 (Fig. 5) mainly located offshore Spain. Even though seismic unit SU2 has not been formally identified offshore Morocco, seismic unit SU3 drilled in the Andalucia-G1 borehole, also incorporates pre-Langhian foraminifers and could also be a source of mud.

In the Betic and Rif hinterlands, the Langhian is marked by the sedimentation of an olistostromic formation separated from the Early Miocene by a sedimentary hiatus (Zaghloul et al., 
2010; Suades and Crespo-Blanc, 2013). In the Alboran Sea, our seismic interpretation shows that the Late Burdigalian-Langhian unit (SU3) is also separated from the late Aquitanian-Burdigalian unit (SU2) by an unconformity (Fig. 5, 7). Offshore Morocco, this basal sequence is deposited at the foot of the tilted and pre-structured Ghomaride unit (Fig. 10, 11, 13C, 15 cross-section b) but the distinction between the SU2 and SU3 is not clear.

From the Serravallian, the Alboran Sea was filled by a thick clastic and volcanoclastic sequence (SU4) (Fig. 10, 11, 15 cross section c) during a global regression cycle (Hardenbol et al., 1998). That period marks the onset of the most significant subsidence phase of the basin interpreted as sag bahavior. In the Betic and Rif hinterlands, the Serravallian is marked by hiatus and subaerial erosion of the region surrounding the WAB (Morel, 1987; Cunningham et al., 1997; López-Garrido and Sanz de Galdeano, 1999) when the southeastern Betics basins were subject to marine sedimentation (Soria, 1993). Internal reflector geometries and unconformities observed in the seismic data (Fig. 5, 6, 10, 11) show an irregular subsidence rate during the deposition of SU4, thus arguing against a simple thermal contraction model following exhumation of the Alpujarride/Sebtide complex. The Serravallian depocenter appears to be homogeneous and has a curved shape, locally reaching $2 \mathrm{~s}$ TWTT (Fig. 13). This period of active subsidence is correlated with the uplift of the Betic and Rif hinterlands during the forelandward formation of fold-and-thrust belts (see synthesis in Crespo-Blanc and Frizon de Lamotte, 2006; Chalouan et al., 2008). The unconformity marking the top of sub-unit SU4b in the upper Serravallian is coeval with a major volcanic period recorded in the entire basin (Duggen et al. 2005, 2008). The angular unconformity could thus be explained by the growth and thermal uplift of the Trans-Alboran magmatic arc. The Lower Tortonian is marked by continuous turbiditic sedimentation that filled the Alboran Sea basin with a slight deviation of the depocenter toward the south of the WAB (Fig. 13E). Offshore Morocco, SU5 does not display large-scale extensional features while syn-sedimentary faulting associated with rollover structure has been documented in the Spanish margin (Soto et al., 2010). According to these authors, this period also corresponds to the latest extensional deformation due to gravity sliding. This period ends at the late Tortonian when the entire Alboran area started to be inverted after the cessation of E-W extension in the Alboran realm under the African plate convergence.

The late Tortonian tectonic inversion affected the southernmost border of the WAB where the Xauen Bank began to develop its actual transpressive structure made up of a succession of antiforms/synforms over a sinistral strike-slip set of faults (Fig. 13; Chalouan et al., 1997). In response to the tectonic inversion, the main depocenter (SU6) developed in front of the Xauen Bank. In the deepest part of the WAB, the irregularity of the basement interface as well as the geometry of faulted folds argue in favor of a transpressive structure cross-cutting the basin along a roughly NW-SE trend (Fig. 13A). The apparent discontinuity of these structures suggests that a set of en-echelon faults affects the basin. Taking the NW to $\mathrm{N}$ verging convergence of the African plate into account 
(Serpelloni et al., 2007), these en-echelon faults could have had a dextral strike-slip component.

The progressive compressive tectonics, in addition to glacio-eustatic variations, led to successively closure of the marine corridors connecting the Alboran Sea to the Atlantic and, to a more regional extent, the entire Mediterranean Sea (Krijgsman et al., 1999 ; Garcés et al., 2001; Martín et al., 2001; Warny et al., 2003) ending with the Messinian Salinity Crisis (MSC). In the Alboran Sea basin, deposition of evaporites is postulated because of the occurrence of interlayered gypsum and anhydrite beds in Andalucia-G1 borehole (Fig. 4). MSC related deposits in the Alboran Sea are relatively thin across the WAB and reworked within mass-transport deposits (Martínez del Olmo and Comas, 2008; Martínez del Olmo, 2011). The return of marine conditions is marked by the Pliocene and Quaternary sequence (SU8) dominated by contourites, turbidite fans and sedimentary instabilities formed by the interplay between the Mediterranean water masses, glacio-eustatic changes and the rapid morphological changes due to active tectonic inversion (Hernández-Molina et al., 2011).

To sum up, the WAB experienced three stages of subsidence comprising (1) initial rapid subsidence induced by an extensional detachment, (2) a large subsidence pulse in the Serravallian and Tortonian up to (3) the tectonic inversion of the entire domaine and the resulting centripetal subsidence.

\section{Geodynamic implications}

\subsection{Paleogeographic reconstructions}

In the following, we present paleogeographic reconstructions (Fig. 16) from the late Oligocene to the present through which the initiation, development and migration of the Western Alboran Basin will be discussed. Paleogeographic maps were built relative to Iberia, going backward in time, but which we present from the oldest to the most recent. In parallel, four synthetic cross sections were drawn across the whole Betic-Rif orogenic system to follow its evolution (Fig. 17). The reconstructions are based on a simple scenario that involves a three-step evolution of the back-arc basin since the Oligocene (Jolivet et al., 2003, 2006, 2008). The first period (before $20 \mathrm{Ma}$ ) witnessed the early development of the back-arc basin associated with N-S extension, the activity of the detachment localized between the Malaguides-Ghomarides and the Alpujarride-Sebtides, and the first development of sedimentary basins in the internal zones of the Betics. The second period saw a dramatic change in the direction of extension from N-S to E-W and the rapid westward motion of the Alboran domain until the renewal of N-S compression some 7 Ma ago. The map of the distribution of marine and land areas was drawn after Dercourt et al. (1993), Meulenkamp and Sissingh (2003), and Gibert et al. (2013). 


\subsubsection{Oligocene}

In the Oligocene (30-25 Ma), the N-dipping subducted slab had a NNE-SSW oriented front that progressively retreated southward toward the North African margin. The main consequences were the first back-arc extension in the Alboran domain, intracontinental shortening in the Mesorif unit (Michard et al., 2002) and subsidiary shortening along the Atlas system previously build up in the Eocene (Fig. 16; Frizon de Lamotte et al., 2000, 2008). The latest Oligocene is marked by the intracrustal emplacement of peridotite slices within Alpujarride units (Fig. 17A; Hidas et al., 2013; Precigout et al., 2013).

The internal Alboran domain progressively emerges, as the Malaguide-Ghomaride nappe becomes the source of the External Betic foredeep sediments (Vera, 2000). A first magmatic occurrence, characterized by tholeiitic dyke intrusions (Turner et al., 1999; Duggen et al., 2004), marks the extensional deformation that affected the upper Malaguide/Ghomaride nappe (Zaghloul et al., 2003; Serrano et al., 2007; Hlila et al., 2008). This extensional deformation resulted in the formation of small-scale basins where sedimentation is mostly terrigenous (Fig. 17A). In the late Oligocene, top-to-the $\mathrm{N}$ detachment tectonics led to the progressive unroofing of the Alpujarride/Sebtide basement currently forming the topographic high of the Alboran Sea (Fig. 1, 2A). Given the space available between the African and Iberian plates, as well as the extensional kinematics onshore, we infer that a SW-dipping detachment fault controlled the deposition of sediments and the coeval unroofing of the Alpujarride/Sebtide complex.

\subsubsection{Aquitanian-Burdigalian}

The southward retreat of the N-dipping subducted slab reached the African plate. This period saw the start of nappe emplacement in the frontal zones of the Betics and the Rif (Fig. 16; Lonergan and White, 1997; Platt et al., 2003a). The Alpujarride/Sebtide complex shows syn-exhumation deformation associated with N-S to NE-SW trending stretching lineations (Crespo Blanc et al., 1994, Crespo Blanc, 1995; Balanyá et al., 1997; Platzman and Platt, 2004; Rossetti et al., 2005; Negro et al., 2008). A late Aquitanian thermal event affected the whole Alboran domain (Comas et al., 1999; Soto and Platt, 1999) producing anatectic rocks and resetting most chronometers in the metamorphic rocks of the Alpujarrides (Fig. 16). This event has been correlated with an influx of hot asthenosphere material (Fig. 17; Negro et al., 2006; Jolivet et al., 2006).

Backstripping reconstructions have shown that the subsidence and first sediment loading in the Alboran Sea basin and in the southern Betics began in the late Oligocene-Early Miocene (i.e. 25$20 \mathrm{Ma}$; Docherty and Banda, 1995; Hanne et al., 2003). The Burdigalian then underwent a rotation of the direction of extension from N-S to E-W (Fig. 16; Jolivet et al., 2008). This particular change is interpreted as resulting from a westward slab tearing off from the North African slab. Contemporaneously with this dramatic change in extensional direction, the Western Alboran Basin 
received its first sedimentary sequence unconformably covering the Malaguide/GhomarideAlpujarride/Sebtide extensional contact (our SU2 and part of SU3, Fig. 17B). To accommodate the exhumation of the Ronda and Beni Bousera mantle peridotites, the Malaguide/GhomarideAlpujarride/Sebtide contact visible in the WAB probably acted as a NNE-verging detachment ramp (Fig. 17).

\subsubsection{Langhian-Serravallian}

The Early Miocene-Middle Miocene transition marks a counterclockwise rotation of the direction of the African plate convergence (Fig. 16; Dewey et al., 1989; Rosenbaum et al., 2002a). Paleodynamic reconstructions correlate this rotation with a significant westward movement of the subduction zone (Lonergan and White, 1997; Jolivet et al., 2003, 2006). This westward shift has been interpreted as the result of the roll-back and steepening of a narrow remnant of slab (Duggen et al., 2005) or as the lateral tearing of the Tethys lithosphere subducted beneath the Betics (Wortel and Spakman, 2000). The External Zones of the Betic and Rif areas are marked by the forelandward progression of the compressional deformation, oblique collision in the Rif (Chalouan et al., 2006) as well as the development of both the Guadalquivir and Gharb basins (Fig. 16). The shortening affecting the Flysch domain progressively diminished and local extension occurred (Crespo-Blanc and Frizon de Lamotte, 2006). At that time, the Gulf of Cadiz Imbricate Wedge developed in front of the migrating arcuate orogen (Maldonado et al., 1999; Medialdea et al., 2004). The Betic Internal Zones are marked by E-W extension with top-to-the W shearing of the lowermost Nevado-Filabride complex (Fig. 16; Jabaloy et al., 1993; Johnson et al., 1997; Augier et al., 2005b;). The late Serravallian extensional tectonics caused basin subsidence in the southeastern Betics (Rodríguez-Fernández et al., 2011) and then the early formation of sedimentary basins between the exhumed metamorphic domes (Fig. 17C; Ott d'Estevou and Montenat, 1990; Augier et al., 2013; Do Couto et al., 2014b).

In the Langhian, sedimentation of the in the peripheral basins is characterized by olistostromic formations made up of external zones with blocks embedded in a shaly matrix (Serrano et al., 2007; Hlila et al., 2008; Suades and Crespo-Blanc, 2013). In the Western Alboran Basin (SU3 unit) the Langhian is marked by the alternation of greenish to reddish clays with intercalated silts with local overpressure levels (Comas et al., 1999). The transition to the Serravallian is well marked in the basin by an unconformity below a thick Serravallian siliciclastic sequence characterized by turbiditic deposits. Offshore the Spanish margin, Serravallian deposits unconformably cover the oldest extensional system coeval with the formation of the Alboran basin (Martínez del Olmo and Comas, 2008). This period saw the beginning of gravity-driven tectonics (Soto et al., 2010). Offshore Morocco, the architecture of this sequence points to a sudden acceleration in subsidence in the WAB and sag-type behavior. This observation can be correlated with the still attached subducted slab underneath the North African margin and beneath the Betics. 


\subsubsection{Tortonian}

The Tortonian is a turning point in the evolution of the Betic-Rif orogen. The westward escape of the Alboran domain nearly stopped as it has been observed in the Gulf of Cadiz and in the Flysch domain (Medialdea et al., 2004; Crespo-Blanc and Frizon de Lamotte, 2006). In the eastern Rif, the final oblique emplacement of the Alboran domain over the African plate is also marked by the top-tothe SW exhumation of the Temsamane units (Fig. 16; Negro et al., 2006; 2008; Booth-Rea et al., 2012).

The Tortonian deposits observed in the Betics seal the latest top-to-the WSW extensional shear zone (Crespo-Blanc et al., 1994; Augier et al., 2013). In the southeastern Betic Cordillera, the Early Tortonian is characterized by the continuation of extensional tectonics and basin subsidence (Ott d'Estevou and Montenat, 1990; Augier et al., 2013; Do Couto et al., 2014b). Extension continued until $\sim 9$ to $8 \mathrm{Ma}$ when an uplift of the basin basement is recorded and extensional basins became partly inverted under the NNW convergence of the African and Eurasian plates (Fig. 17D; Weijermars et al., 1985; Vissers et al., 1995; Augier et al., 2013; Do Couto et al., 2014b).

The Tortonian sedimentation in the WAB is marked by two thick siliciclastic sequences (SU5a and b) made of turbiditic layers interbedded in hemipelagic sediments (Comas et al., 1999) and showing a centripetal thickening in the WAB. These two SU5a and SU5b sequences are separated by a striking unconformity marking the onset of the compressive strain affecting the entire Alboran area (Martínez-García et al., 2011, 2013). This unconformity, which was also observed by Talukder et al. (2003) appears to mark the end of a major episode of mud volcanic activity in the northern WAB. In the Alboran Sea, regional compression was accommodated along several strike-slip faults including the left-lateral Xauen-Alboran Ridge and Carboneras faults associated with the right-lateral Yusuf Fault (Fig. 16; Chalouan et al., 1997; Ballesteros et al., 2008; Martínez-García et al., 2011, 2013). A roughly NNW-SSE-oriented transpressional fault zone also affected the WAB (Fig. 13). In the Betic Cordillera, compression resulted in the progressive uplift of various intramontane basins (Iribarren et al., 2009).

\subsubsection{Messinian to present}

Geodynamic reconstructions of the Messinian and present-day stages are similar (Fig. 16). Since the late Tortonian, the Betic-Rif system has been subjected to N-S compression and the Edipping slab remains active (Comas et al., 1999; Gutscher et al., 2002; Duarte et al., 2013). During the Messinian, this N-S compression together with eustatic fluctuations, progressively closed the Messinian corridors that had previously enabled the Mediterranean Sea to be filled with water from the Atlantic ended with the Messinian Salinity Crisis (Hsü et al., 1973; Jolivet et al., 2006; CIESM, 2008; Do Couto et al., 2014a). Deformation of the WAB continues today and is marked by the inversion of the Xauen-Alboran Ridge transpressive fault (Watts et al., 1993; Comas et al., 1999; 
Martínez-García et al., 2011, 2013). The long-term effects of this shortening strain tend to delineate a domain escaping toward the southwest (Nocquet, 2012 and references therein) while the African crust slides against the Alboran domain. Since the late Tortonian and the tectonic inversion, the Alboran basin has evolved as a flexural basin. The post-Messinian reflooding of the area is marked by a large amount of contourite systems induced by currents that affected the Mediterranean in the PlioQuaternary (Alonso et al., 1999; Palomino et al., 2011; Somoza et al., 2012).

\subsection{Location of the Alboran domain in the Early Miocene}

Kinematic models proposing a slab rollback evolution of the westernmost Mediterranean involve a trench displacement of about 200 to $800 \mathrm{~km}$ (Rosenbaum et al., 2002a; Faccenna et al., 2004; Spakman and Wortel, 2004; Jolivet et al., 2008). The reconstructed location of the internal Alboran domain thus varies considerably. Furthermore, it has been interpreted either as part of the Iberian margin or as an isolated microcontinent within the western Tethyan realm (Michard et al., 2006). The farthest location puts the internal Alboran domain at the emplacement of the present-day Valencia trough (Rosenbaum et al., 2002a), while other models propose a less distant origin south of the present-day Balearic Islands (Lacombe and Jolivet, 2005; Jolivet et al., 2006). This assumption was re-assessed by Chalouan et al. (2008) based on plate kinematic reconstructions proposed by Schettino and Turco (2006). This location fits the African craton source and the southward paleogeographic extension of the Flychs units to the Alboran domain (Thomas et al., 2010; Guerrera et al., 2012; Alcalá et al., 2013), as well as the Iberian craton provenance of plutonic pebbles retrieved from the Oligocene-Miocene cover of the Malaguide-Ghomaride complex (Gigliuto et al., 2004; Puglisi, 2008). We therefore adopt this configuration as the location of the Alboran domain during the Early Miocene (Fig. 16). From the Early Miocene onward, our paleogeographic reconstructions indicate a westward slab retreat of about 600 to $700 \mathrm{~km}$ at an average velocity of 5 to $6 \mathrm{~cm} / \mathrm{yr}$ (Fig. 16). Such a displacement is in agreement with previous estimates (Royden, 1993; Lonergan and White, 1997). The main acceleration step is thought to have taken place between the Burdigalian and Serravallian as the slab progressively detached along the North African margin and then beneath the Betic Cordillera (Jolivet et al., 2006). This rapid westward roll-back caused the Alboran domain to overthrust the Flysch domain toward the west, the External Betics toward the north and the External Rif toward the southwest. A decrease in roll-back velocity occurred in the late Miocene, coeval with the resumption of compression after ca. $8 \mathrm{Ma}$.

The present day configuration of the WAB has an arcuated shape that mimics the curvature of the Gilbraltar Arc (Fig. 2A). It is the result of successive extensional and compressional tectonics and we assume that the basin acquired its present shape in the late Tortonian, when the seismic unit SU6 covered and sealed most of the previous deformation. Unless a complete $3 \mathrm{D}$ restoration of the WAB is 
undertaken, it will be complicated to recover the previous shape of the basin. Nevertheless, given the geodynamic restoration of the southwestern Mediterranean area (Fig. 16), the significant change in lithology from the shale-rich Burdigalian-Langhian (SU2 and SU3) to the Serravallian siliciclastic seismic units (SU4), we assume that the basin underwent a vertical-axis rotation, most probably clockwise, from the end of the Burdigalian up to the Langhian period. This would correspond to the change in the extensional regime recorded in the underlying metamorphic basement, from $\tilde{\mathrm{N}}-\mathrm{S}$ to $\sim \mathrm{E}-$ W (Fig. 15, 17).

\subsection{Causes of the subsidence and migration of the WAB}

In comparison with other onshore basins on the Betic and Rif belts, the Western Alboran Basin is surprisingly thick and, apart from recent localized compressional structures, hardly deformed (Ballesteros et al., 2008; Martínez-García et al., 2011, 2013). A thick pile of sediments has accumulated from the Early Miocene to the present with a depocenter that has not moved significantly with respect to the outline of the basin. During the westward retreat of the slab, one could have expected instead a migrating depocenter and overall regional extensional deformation like in the northern Apennines, for instance (Jolivet et al., 1998). However, each sedimentary sequence unconformably covers the lower one, leading to the expansion of the basin area (Fig. 13). In comparison, onshore extensional basins are much thinner and are affected by numerous normal faults and detachments (Crespo-Blanc et al., 1994; Crespo-Blanc, 1995; Meijninger and Vissers, 2006; Augier et al., 2013; Do Couto et al., 2014b). Such a difference in the tectonic style suggests a distinct formation process. The WAB most probably migrated westward together with the slab but with no significant deformation, while the metamorphic zones underneath were progressively extracted thanks to a series of detachments. Extensional detachments usually do not produce deep thick basins, as they tend to smear the deposition of sediments while progressively offsetting depocenters. The postCaledonian Devonian basins in Norway are examples of this behavior (Seranne and Séguret, 1987; Osmundsen and Andersen, 1994), as are the southern Betics basins (Crespo-Blanc et al., 1994; Crespo-Blanc, 1995; Meijninger and Vissers, 2006; Augier et al., 2013).

The WAB does not follow this classical behavior. One possible explanation for the seemingly stable basin in such an unstable environment with a fast migrating upper plate and a constrained environment is that the basin has always been situated above the hinge of the retreating slab, as is the case today (Fig. 3). According to this hypothesis, the cause of subsidence was the constant presence of a dense anomaly at depth below the WAB that would depress the surface of the upper plate lithosphere thereby creating a space for sediment deposition (Fig. 18). As the slab migrated westward, the depocenter migrated at the same rate, and the underlying metamorphic domain was exhumed and the crust progressively thinned (Fig. 18). Such mechanical behavior has been used to explain the 
subsidence and deformation of the Transylvanian sag basin (Tiliţă et al., 2013) and the larger intraCarpathians realm (Matenco et al., 2007; Ismail-Zadeh et al., 2012).

The situation of the Western Alboran Basin is both specific and original at the edge of an active subduction zone. Paleomagnetic rotations on either side of the Gibraltar arc have been interpreted as reflecting Subduction-Transform Edge Propagator (STEP) fault activity at the edges of the lateral slab (Govers and Wortel, 2005). Very few places on Earth are in the same configuration but the integrated geodynamic model of the Alboran Sea and surroundings could actually be used as a model for other sedimentary basins in comparable situations such as the Cretan Sea, the Banda Sea or in the Caribbean Sea.

\subsection{Geodynamic, tectonic and sedimentary implications}

After a major change in the Mediterranean subduction regime during the Oligocene (Réhault et al., 1984; Faccenna et al., 1997; Jolivet and Faccenna, 2000; Jolivet et al., 2008), the Tethyan subduction retreated progressively southward. From $\sim 30$ to $20 \mathrm{Ma}$, the Tethyan slab retreated toward the North African margin (Fig. 16). The Alboran domain consequently underwent N-S extension that led to the formation of low-angle normal faults in the Alpujarride/Sebtide complex following $\mathrm{N}-\mathrm{S}$ ductile stretching. At that time, the WAB and adjacent small-scale satellite basins were formed. According to the primary depositional lithology, the first resulting subsidence pulse was relatively slow, characterized by coarse-grained conglomerates and pebbly sandstones evolving to more distal shale and turbidites (Zaghloul et al., 2003; Serrano et al., 2007; Hlila et al., 2008). The dispersal of these outcrops onland as well as their subsequent tectonic deformation make it difficult to construct a paleogeographic map showing the connections between basins over time. Nevertheless, the common subsidence and sedimentation histories of the southern Betics and Rif sub-basins suggest an interconnection of marine corridors and depocenters (Fig. 16).

In the Lower Burdigalian, at $20 \mathrm{Ma}$, a sudden event resulted in a widespread thermal overprint and local crustal anatexy (Platt and Whitehouse, 1999). During this period, N-S extension was still active in the Alpujarride/Sebtide complex (Fig. 18), active deposition of marine sediments occurred in the WAB (SU2 unit and probably part of the lowermost SU3), while E-W extension was starting to affect the underlying Nevado-Filabride complex (Augier et al., 2005b). This particular change can be interpreted as the transition from southward to westward slab retreat. Subsequently, the whole Alboran domain migrated, driven by westward roll-back, tearing and local detachments of the subducting plate (Lonergan and White, 1997; Duggen et al., 2004, 2005, 2008; Spakman and Wortel, 2004). That period also corresponds to the first occurrence of bimodal calc-alkaline magmatism in the northern Algerian margin which has been interpreted as the first geochemical evidence of slab tearing (Fig. 18; Maury et al., 2000; Coulon et al., 2002). In comparison with the late Oligocene-Aquitanian 
configuration, the sedimentary context of the WAB remained quite similar in the sense that above the first late Oligocene-Early Miocene formations, a slight and mostly coastal unconformity is dated to the Aquitanian-Burdigalian boundary. The lithology of the overlying Burdigalian sequence indicates minor deepening of the basin (Serrano et al., 2007; Hlila et al., 2008). Such unconformity, combined with the exhumation of the Alpujarride/Sebtide rocks and their embedded peridotites (Afiri et al., 2011), can be explained by the concomitance of top-to-the $\mathrm{N}$ low-angle normal faulting in the backarc region and frontal thrusting of the Alboran domain over Africa (Fig. 16, 17, 18).

E-W extension proceeded through the Langhian and Serravallian together with the westward spread of the calc-calkaline magmatism in the North African margin (Fig. 16, 18). The inception of the Trans-Alboran calc-alkaline magmatism, marking the position of the deep subducted Tethyan lithosphere beneath the Alboran basin (Duggen et al., 2005, 2008) took place in the Serravallian. The Nevado-Filabride complex was exhumed thanks to top-to-the WSW extensional shear zones (GarcíaDueñas et al., 1992; Jabaloy et al., 1993; Martínez-Martínez et al., 2002a) while the Alpujarride/Sebtide complex was affected by top-to-the-N brittle normal faulting (Crespo-Blanc et al., 1994; Rossetti et al., 2005), coeval with the gravity-driven deformation of the WAB offshore Spain (Soto et al., 2010). Two E-W oriented metamorphic domes were then progressively exhumed from E to $\mathrm{W}$ revealing the progressive evolution from ductile to brittle deformation (Augier et al., 2005b; 2013) and triggering sedimentary deposition in the basins involved (Meijninger and Vissers, 2006; Augier et al., 2013; Do Couto et al., 2014b). The cartographic contour of the W-verging extensional detachment shows a complex curved pattern in the southeastern Betics (Fig. 18). In the WAB, this period saw the deposition of the Langhian shales in the SU3 unit and the following thick siliciclastics SU4 units. It is noteworthy that the thickest deposition of sediments in the WAB took place just after the extensional tectonic change. Acoording to the seismic profiles, no major extensional deformation took place during the westward movement of the WAB, in contrast to the tectonic style documented offshore Spain (Soto et al., 2010).

The assumption of slab tearing during the westward slab roll-back causing E-W extension in the southeastern Betics was reinforced by Le Pourhiet et al. (2012), who showed that metamorphic domes elongated parallel to the stretching direction (a-type domes, Jolivet et al., 2004) can form thanks to a strike-slip shearing component. From the Langhian to Serravallian, the WAB filling underwent a substantial dynamic change. It is worth noting that the thickest sequence identified in the $\mathrm{WAB}$ is made up of siliciclastic deposits dated to the Serravallian and exceeding $3 \mathrm{~km}$ in thickness in the deepest part of the basin (Fig. 13). Backstripping analysis of the northeastern Alboran Sea and southern Betics revealed three periods of subsidence that took place in the Langhian ( 15.5-14.5 Ma), Serravallian ( 13-10.7 Ma) and in the Pliocene-Pleistocene (Rodríguez-Fernández et al., 1999). In this geodynamic context, we suggest that these two successive Middle Miocene subsidence pulses were driven by the two successive North African and southern Betics slab tearing events. In the 
Tortonian, the WAB acquired its curved shape mimicking that of the Gibraltar arc, which was about to stop its westward overthrust (Crepo-Blanc and Frizon de Lamotte, 2006).

The westward slab retreat remained active until $\sim 8 \mathrm{Ma}$ and the compressive inversion of the entire area (Fig. 16; Chalouan et al., 1997; Ballesteros et al., 2008; Martínez-García et al., 2011, 2013). Paleomagnetic rotations continued in the Betics after the late Miocene, evidence for continuing displacement around the Gibraltar arc, probably favored by the contractional reorganization and a still active slab pull underneath (Mattei et al., 2006; Duarte et al., 2013). Today, the hinge of the subducted slab is still located underneath the deepest part of the basin. One can assume that this situation has been unchanged since the late Tortonian as no major recent deformation has been observed. We therefore postulate that the late Tortonian to recent thick sedimentary accumulation is the result of the N-S contraction of the Alboran domain (Cloetingh et al., 1992; Garcia-Castellanos et al., 2002) driven by slab-pull at depth.

\section{Conclusions}

Based on analyses of recent 2D seismic profiles, combined with older seismic data and compiled field data, the tectonic and stratigraphic history of the Western Alboran Basin is clarified here.

Our stratigraphic analysis showed that a thick, pre-rift sequence is preserved beneath the Miocene Western Alboran basin. Land to sea correlations lead us to interpret this pre-rift series as the topmost Malaguide/Ghomaride nappe composing the Alboran domain, currently resting on top of the metamorphic basement. This series contains basal and internal interfaces thought to have acted as detachment faults during the Early Miocene exhumation of the underlying Alpujarride/Sebtide complex as well as during sediment loading of the basin coeval with the uplift of the Betic and Rif hinterlands.

The WAB and surrounding satellite basins record a low late Oligocene-Early Miocene subsidence phase generated by N-S extension exhuming the Alpujarride/Sebtide complex through deep rooted top-to-the $\mathrm{N}$ extensional detachment. In the meantime, the Alboran domain started to overthrust the Betic-Rif external zones. At the end of the Burdigalian, the N-S to E-W rollback transition triggered a moderate subsidence step in the WAB and adjacent basins. As E-W extension proceeded westwards, slab tearing occurred beneath the Betics leading to the exhumation of two E-W elongated domes, thereby triggering the onset of subsidence in the southeastern Betics. This modification of the lithospheric configuration largely affected the WAB, which recorded the onset of a strong subsidence phase, marked by an up to $3 \mathrm{~km}$ thick Serravallian sequence. This notable subsidence lasted until the late Tortonian and the inversion of the entire Alboran domain that marks 
the beginning of the flexural filling of the WAB.

After the syn-rift sequence following unroofing of the metamorphic rocks dated to the BurdigalianLanghian, the basin is marked by a basinwide subsidence period (sag basin) concomitant with high sedimentary influx that eroded the continuously uplifted hinterlands. Paleogeographic and paleodynamic reconstructions of the southwestern Mediterranean Sea from the Oligocene to the present illustrate the creation, migration and subsidence history of the Western Alboran Basin in relation with large-scale lithospheric processes. The roughly perpendicular change in slab rollback changed the shape of the WAB. Our observations, together with the tectonic timing of adjacent areas, suggest that the Western Alboran Basin has always been located above the hinge of the retreating slab, and that the slab-pull force has driven its subsidence. It is noteworthy that, apart from the gravitydriven deformation on the Spanish margin, the WAB has only a small number of normal faults, even with respect to the SW-NE basin-scale seismic lines parallel to the main extensional phase of tectonic evolution. We thus assume that the WAB was located above the dipping slab during its entire evolution and migrated with the retreating slab from east to west. We propose that the main cause of the rapid subsidence leading to the deposition of $\sim 10 \mathrm{~km}$ of sediments in the center of the basin was the constant load of the downgoing slab during its westward retreat. The late Tortonian was marked by the tectonic inversion of the entire southern part of the basin, associated with a northward migration of the depocenter. The subsequent deformation was mostly localized above the thickest SerravalianLower Tortonian depocenters. After intense erosion related to the Messinian Salinity Crisis and reflooding of the basin, the Pliocene and Quaternary is marked by the still ongoing compressive strain, trapping a large amount of sediments along contouritic and turbiditic currents.

\section{Acknowledgments}

This work was funded by the CIFRE $\mathrm{PhD}$ grant 584/2010 (TOTAL/UPMC). This paper is a contribution to the Projects AMEDITER ("Actions Marges" CNRS/INSU Programme) and TerMEx (CNRS/INSU). We are grateful to the University Mohammed V of Rabat and the ONHYM (Office National des Hydrocarbures et des Mines du Maroc) for sharing the data on the Moroccan margin. We also warmly thank the ICM-CSIC laboratory in Barcelona for multi- and single-channel seismic profiles (http://www.icm.csic.es/geo/gma/SurveyMaps/; http://www.igme.es/internet/sistemas_infor/BASESINTERNET/sigeof.htm), Daphne Goodfellow for her language corrections and comments on the manuscript, and Alexandre Lethiers for his support with the illustrations. We want to thank Rob Govers and two anonymous reviewers for their suggestions that helped us improve the manuscript. The processed seismic data were interpreted thanks to the IHS Kingdom ${ }^{\circledR}$ software. 


\section{References}

Afiri, A., Gueydan, F., Pitra, P., Essaifi, A., Précigout, J., 2011. Oligo-Miocene exhumation of the Beni-Bousera peridotite through a lithosphere-scale extensional shear zone. Geodinamica Acta 24, 4960.

Alcalá, F.J., Guerrera, F., Martín-Martín, M., Raffaelli, G., Serrano, F., 2013. Geodynamic implications derived from Numidian-like distal turbidites deposited along the Internal-External Domain Boundary of the Betic Cordillera (S Spain). Terra Nova 25, 119-129.

Alonso, B., Ercilla, G., Martínez-Ruiz, F., Baraza, J., Galimont, A., 1999. Pliocene-Pleistocene sedimentary facies at Site 976: depositional history in the northwestern Alboran Sea. Proceeding of the Ocean Drilling Program, Scientific Results 161, p.57-68.

Ammar, A., Mauffret, A., Gorini, C., Jabour, H., 2007. The tectonic structure of the Alboran Margin of Morocco. Rev. Soc. Geol. Espana 20, 247-271.

Anthonissen, D.E., Ogg, J.G., 2012. Cenozoic and Cretaceous Biochronology of Planktonic Foraminifera and calcareous nannofossils. In: The Geologic Time Scale 2012 (Gradstein, F.M., Ogg, J.G., Schmitz, M.D., and Ogg, G.M., editors), Elsevier Publ.: pp.1083-1128.

Augier, R., Agard, P., Monié, P., Jolivet, L., Robin, C., Booth-Rea, G., 2005a. Exhumation, doming and slab retreat in the Betic Cordillera (SE Spain): in situ 40Ar/39Ar ages and P-T-d-t paths for the Nevado-Filabride complex. J. metamorphic Geol. 23, 357-381.

Augier, R., Jolivet, L., Robin, C., 2005b. Late Orogenic doming in the eastern Betic Cordilleras: Final exhumation of the Nevado-Filabride complex and its relation to basin genesis. Tectonics 24, TC4003.

Augier, R., Jolivet, L., Do Couto, D., Negro, F., 2013. From ductile to brittle, late- to post-orogenic evolution of the Betic Cordillera: Structural insights from the northeastern Internal zones. Bulletin De La Societe Geologique De France 184, 405-425.

Balanyá, J.C., García-Dueñas, V., Azáñon, J.M., Sánchez-Gómez, M., 1997. Alternating contractional and extensional events in the Alpujarride nappes of the Alboran Domain (Betics, Gibraltar Arc). Tectonics 16, 226-238.

Ballesteros, M., Rivera, J., Muñoz, A., Muñoz-Martín, A., Acosta, J., Carbó, A., Uchupi, E., 2008. Alboran Basin, southern Spain-Part II: Neogene tectonic implications for the orogenic float model. Marine and Petroleum Geology 25, 75-101.

Berástegui, X., Banks, C.J., Puig, C., Taberner, C., Waltham, D., Fernàndez, M., 1998. Lateral diapiric emplacement of Triassic evaporites at the southern margin of the Guadalquivir Basin, Spain. Geological Society, London, Special Publications 134, 49-68.

Bezada, M.J., Humphreys, E.D., Toomey, D.R., Harnafi, M., Dávila, J.M., Gallart, J., 2013. Evidence for slab rollback in westernmost Mediterranean from improved upper mantle imaging. Earth and Planetary Science Letters 368, 51-60.

Blinova, V.N., Comas, M.C., Ivanov, M.K., Poludetkina, E.N., Matveeva, T.V., 2011. Active mud 
volcanism in the West Alboran Basin: Geochemical evidence of hydrocarbon seepage. Marine and Petroleum Geology 28, 1483-1504.

Booth-Rea, G., Ranero, C., Martínez-Martínez, J.M., Grevemeyer, I., 2007. Crustal types and Tertiary tectonic evolution of the Alboran sea, western Mediterranean. Geochem. Geophys. Geosyst. 8, Q10005.

Booth-Rea, G., Jabaloy-Sánchez, A., Azdimousa, A., Asebriy, L., Vázquez Vílchez, M., MartínezMartínez, J.M. 2012. Upper-crustal extension during oblique collision: the Temsamane extensional detachment (eastern Rif, Morocco). Terra Nova 24, 505-512.

Bourgois, J., Mauffret, A., Ammar, A., Demnati, A., 1992. Multichannel seismic data imaging of inversion tectonics of the Alboran Ridge (western Mediterranean Sea). Geo-Marine Letters 12, 117 122.

Buforn, E., Bezzeghoud, M., UdÍas, A., Pro, C., 2004. Seismic Sources on the Iberia-African Plate Boundary and their Tectonic Implications. Pure and Applied Geophysics 161, 623-646.

Calvert, A., Sandvol, E., Seber, D., Barazangi, M., Roecker, S., Mourabit, T., Vidal, F., Alguaeil, G., Jabour, N., 2000. Geodynamic evolntion of the lithosphere and upper mantle beneath the Alboran region of the western Mediterranean: Constraints from travel time tomography. Journal of Geophysical Research 105, 10871-10898.

Carminati, E., Wortel, M.J.R., Spakman, W., Sabadini, R., 1998a. The role of slab detachment processes in the opening of the western-central Mediterranean basins: some geological and geophysical evidence. Earth and Planetary Science Letters 160, 651-665.

Carminati, E., Wortel, M.J.R., Meijer, P.T, Sabadini, R., 1988b. The two-stage opening of the western-central Mediterranean basins: a forward modeling test to a new evolutionary model. Earth and Planetary Science Letters 160, 667-679.

Catuneanu, O., Abreu, V., Bhattacharya, J.P., Blum, M.D., Dalrymple, R.W., Eriksson, P.G., Fielding, C.R., Fisher, W.L., Galloway, W.E., Gibling, M.R., Giles, K.A., Holbrook, J.M., Jordan, R., Kendall, C.G.S.C., Macurda, B., Martinsen, O.J., Miall, A.D., Neal, J.E., Nummedal, D., Pomar, L., Posamentier, H.W., Pratt, B.R., Sarg, J.F., Shanley, K.W., Steel, R.J., Strasser, A., Tucker, M.E., Winker, C., 2009. Towards the standardization of sequence stratigraphy. Earth-Science Reviews 92, 133.

Chalouan, A., 1986. Les nappes ghomarides (Rif septentrional, Maroc). Un terrain varisque dans la chaine alpine. Ph.D Thesis, Université Louis Pasteur de Strasbourg, 371 pp.

Chalouan, A., Michard, A., 1990. The Ghomarides nappes, Rif coastal range, Morocco: a variscan chip in the Alpine belt. Tectonics 9(6), 1565-1583.

Chalouan, A., Saji, R., Michard, A., Bally, A.W., 1997. Neogene tectonic evolution of the southwestern Alboran basin as inferred from seismic data off Morocco. AAPG Bull.-Am. Assoc. Petr. Geol. 81, 1161-1184.

Chalouan, A., Michard, A., 2004. The Alpine Rif Belt (Morocco): A Case of Mountain Building in a Subduction-Subduction-Transform Fault Triple Junction. Pure and Applied Geophysics 161, 489-519.

Chalouan A., Ouazani-Touhami A., Mouhir L., Saji R., Benmakhlouf, M., 1995. Les failles normales 
à faible pendage du Rif interne (Maroc) et leur effet sur l'amincissement crustal du domaine d'Alboran. Geogaceta, 17, 107-109.

Chalouan, A., Galindo-Zaldívar, J., Akil, M., Marín, C., Chabli, A., Ruano, P., Bargach, K., Sanz de Galdeano, C., Benmakhlouf, M., Ahmamou, M., Gourari, L., 2006. Tectonic wedge escape in the southwestern front of the Rif Cordillera (Morocco), in: Moratti, G., Chalouan, A., (Eds.), Tectonics of the Western Mediterranean and North Africa. Geological Society of London, London, pp. 101-118.

Chalouan, A., Michard, A., Kadiri, Kh, Negro, F., Lamotte, D., Soto, I., J., Saddiqi, O., 2008. The Rif Belt Continental Evolution: The Geology of Morocco, in: Michard, A., Saddiqi, O., Chalouan, A., Frizon de Lamotte, D. (Eds.). Springer Berlin / Heidelberg, pp. 203-302.

CIESM 2008. The Messinian Salinity Crisis from mega-deposits to microbiology - A consensus report in: Briand, F. (Eds.), CIESM Workshop Monographs. Monaco, 168 p.

Cloetingh, S., van der Beek, P.A., van Rees, D., Roep, T.B., Biermann, C., Stephenson, R.A., 1992. Flexural interaction and the dynamics of neogene extensional Basin formation in the Alboran-Betic region. Geo-Marine Letters 12, 66-75.

Comas, M.C., García-Dueñas, V., Jurado, M.J., 1992. Neogene Tectonic Evolution of the Alboran Sea from MCS Data. Geo-Marine Letters 12, 157-164.

Comas, M.C., Platt, J.P., Soto, J.I., Watts, A.B., 1999. The origin and tectonic history of the Alboran basin: insights from leg 161 results. Proceeding of the Ocean Drilling Program, Scientific Results 161, $555-580$.

Coulon, C., Megartsi, M., Fourcade, S., Maury, R.C., Bellon, H., Louni-Hacini, A., Cotten, J., Coutelle, A., Hermitte, D., 2002. Post-collisional transition from calc-alkaline to alkaline volcanism during the Neogene in Oranie (Algeria): magmatic expression of a slab breakoff. Lithos 62, 87-110.

Crespo-Blanc, A., Orozco, M., García-Dueñas, V., 1994. Extension versus compression during the Miocene tectonic evolution of the Betic chain. Late folding of normal fault systems. Tectonics 13, 7888.

Crespo-Blanc, A., 1995. Interference pattern of extensional fault systems: a case study of the Miocene rifting of the Alboran basement (North of Sierra Nevada, Betic Chain). Journal of Structural Geology $17,1559-1569$.

Crespo-Blanc, A., Frizon de Lamotte, D., 2006. Structural evolution of the external zones derived from the Flysch trough and the South Iberian and Maghrebian paleomargins around the Gibraltar arc: a comparative study. Bulletin De La Société Géologique De France 177, 267-282.

Cunningham, K.J., Benson, R.H., Rakic-El Bied, K., McKenna, L.W., 1997. Eustatic implications of late Miocene depositional sequences in the Melilla Basin, northeastern Morocco. Sedimentary Geology 107, 147-165.

de Jong, K., 1991. Tectono-metamorphic studies and radiometric dating in the Betic Cordilleras (SE Spain). Ph.D Thesis, Vrije Universiteit, Amsterdam, 204 pp.

de Jong, K., 2003. Very fast exhumation of high-pressure metamorphic rocks with excess 40Ar and inherited 87Sr, Betic Cordilleras, southern Spain. Lithos 70, 91-110. 
Dercourt, J., Ricou, L.E., Vrielinck, B., 1993. Atlas Tethys Palaeoenvironmental Maps, GauthierVillars, Paris, 307 pp.

Dewey, J.F., 1988. Extensional collapse of orogens. Tectonics 7, 1123-1139.

Dewey, J.F., Helman, M.L., Turco, E., Hutton, W., Knott, S.D., 1989. Kinematics of the western Mediterranean. Geological Society, London, Special Publications 45, 265-283.

Didon, J., Durand-Delga, M., Kornprobst, J., 1973. Homologies géologiques entre les deux rives du détroit de Gibraltar. Bulletin De La Société Géologie de France 15(2), 77-105.

Docherty, C., Banda, E., 1995. Evidence for the eastward migration of the Alboran Sea based on regional subsidence analysis: A case for basin formation by delamination of the subcrustal lithosphere?, Tectonics, 14(4), 804-818.

Do Couto, D., Popescu, S.-M., Suc, J.-P., Melinte-Dobrinescu, M.C., Barhoun, N., Gorini, C., Jolivet, L., Poort, J., Jouannic, G., Auxietre, J.-L., 2014a. Lago Mare and the Messinian Salinity Crisis: Evidence from the Alboran Sea (S. Spain). Marine and Petroleum Geology 52, 57-76.

Do Couto, D., Gumiaux, C., Augier, R., Lebret, N., Folcher, N., Jouannic, G., Jolivet, L., Suc, J.-P., Gorini, C., 2014b. Tectonic inversion of an asymmetric graben: insights from a combined field and gravity survey in the Sorbas basin. Tectonics, 2013TC003458.

Duarte, J.C., Rosas, F.M., Terrinha, P., Schellart, W.P., Boutelier, D., Gutscher, M.-A., Ribeiro, A., 2013. Are subduction zones invading the Atlantic? Evidence from the southwest Iberia margin. Geology 41, 839-842.

Duggen, S., Hoernle, K., van den Bogaard, P., Harris, C., 2004. Magmatic evolution of the Alboran region: The role of subduction in forming the western Mediterranean and causing the Messinian Salinity Crisis. Earth and Planetary Science Letters 218, 91-108.

Duggen, S., Hoernle, K., van den Bogaard, P., Garbe-Schönberg, D., 2005. Post-Collisional Transition from Subduction- to Intraplate-type Magmatism in the Westernmost Mediterranean: Evidence for Continental-Edge Delamination of Subcontinental Lithosphere. Journal of Petrology 46, 1155-1201.

Duggen, S., Hoernle, K., Klugel, A., Geldmacher, J., Thirlwall, M., Hauff, F., Lowry, D., Oates, N., 2008. Geochemical zonation of the Miocene Alboran Basin volcanism (westernmost Mediterranean): geodynamic implications. Contributions to Mineralogy and Petrology 156, 577-593.

Durand-Delga, M., Feinberg, H., Magné, J. Olivier, P., Anglada, R., 1993. Les formations oligomiocène discordantes sur les Malaguides et les Alpujarrides et leurs implications dans l'évolution géodynamique des Cordillères bétiques (Espagne) et de la Méditerranée d'Alboran. Comptes Rendus de l'Académie des Sciences de Paris, Série II 317, 679-687.

El Kadiri, K., Serrano, F., Hlila, R., Liemlahi, H., Chalouan, A., López-Garrido, A.C., GuerraMerchán, A., Sanz de Galdeano, C., Kerzazi, K., Mrihi, A.E., 2005. Lithostratigraphy and sedimentology of the latest Cretaceous-early Burdigalian Tamezzakht succession (Northern Rif, Morocco): consequences for its sequence stratigraphic interpretation. Facies 50, 477-503.

El Kadiri, K, Hlila, R., Sane de Galdeano, D., López-Garrido, A.C., Chalouan, A., Serrano, F., Bahmad, A., Guerra-Merchan, A., Liemlahi, H., 2006. Regional correlations across the InternidesExternides front (northwestern Rif Belt, Morocco) during the Late Cretaceous-Early Burdigalian 
times: palaeogeographical and palaeotectonic implications, in: Moratti, G., Chalouan, A. (Eds.), Tectonics of the Western Mediterranean and North Africa, pp. 193-215.

Esteban, J.J., Cuvas, J., Tubía, J.M., Sergeev, S., Larionov, A., 2011. A revised Aquitanian age for the emplacement of the Ronda peridotites (Betic Cordilleras, southern Spain). Geological Magazine 148, 183-187.

Estrada, F., Ercilla, G., Gorini, C., Alonso, B., Vázquez, J.T., García-Castellanos, D., Juan, C., Maldonado, A., Ammar, A., Elabbassi, M., 2011. Impact of pulsed Atlantic water inflow into the Alboran Basin at the time of the Zanclean flooding. Geo-Marine Letters 31, 361-376.

Faccenna, C., Mattei, M., Funiciello, R., Jolivet, L., 1997. Styles of back-arc extension in the Central Mediterranean. Terra Nova 9, 126-130.

Faccenna, C., Becker, T.W., Lucente, F.P., Jolivet, L., Rossetti, F., 2001. History of subduction and back-arc extension in the Central Mediterranean. Geophys. J. Int. 145, 1-21.

Faccenna, C., Piromallo, C., Crespo-Blanc, A., Jolivet, L., Rossetti, F., 2004. Lateral slab deformation and the origin of the western Mediterranean arcs. Tectonics 23, TC1012.

Faccenna, C., Becker, T.W., 2010. Shaping mobile belts by small-scale convection. Nature 465, 602605.

Feinberg, H., Maaté, A., Bouhdadi, S., Durand-Delga, M., Maate, M., Magne, J., Olivier, P., 1990. Signification des dépôts de l'oligocène supérieur-miocène inférieur du Rif interne (Maroc), dans l'évolution géodynamique de l'Arc de Gibraltar. Compte rendus de l'académie des Sciences de Paris 310, 1487-1495.

Fernàndez, M., Berástegui, X., Puig, C., García-Castellanos, D., Jurado, J., M., Torné, M., Banks, C., 1998. Geophysical and geological constraints on the evolution of the Guadalquivir foreland basin, Spain. Geological Society, London, Special Publications 134, 29-48.

Flinch, J. F., 1994. Tectonic evolution of the Gibraltar Arc. Ph.D Thesis, Rice University, Houston, Texas, $381 \mathrm{pp}$.

Frizon de Lamotte, D., Saint Bezar, B., Bracène, R., Mercier, E., 2000. The two main steps of the Atlas building and geodynamics of the western Mediterranean. Tectonics 19, 740-761.

Frizon de Lamotte, D., Crespo-Blanc, A., Saint-Bézar, B., Comas, M., Fernàndez, M., Zeyen, H., Ayarza, H., Robert-Charrue, C., Chalouan, A., Zizi, M., Teixell, A., Arboleya, M.L., Alvarez-Lobato, F., Julivert, M., and Michard, A., 2004. TRASNSMED-transect I, In: Cavazza, W., Roure, F., Spakman, W., Stampfli, G.M., Ziegler, P.A. (Eds.), The TRANSMED Atlas - the Mediterranean region from crust to mantle, Springer, Berlin.

Fullea Urchulutegui, J., Fernàndez, M., Zeyen, H., 2005. Lithospheric structure in the AtlanticMediterranean transition zone (southern Spain, northern Morocco): a simple approach from regional elevation and geoid data. C.R. Geosciences 338, 140-151.

Garcés, M., Krijgsman, W., Agustí, J., 2001. Chronostratigraphic framework and evolution of the Fortuna basin (Eastern Betics) since the late Miocene. Basin Research 13, 199-216.

Garcia-Castellanos, D., Fernàndez, M., Torné, M., 2002. Modeling the evolution of the Guadalquivir 
foreland basin (southern Spain). Tectonics 21.

García-Dueñas, V., Balanyá, J.C., Martínez-Martínez, J.M., 1992. Miocene extensional detachments in the outcropping basement of the northern Alboran Basin (Betics) and their tectonic implications. Geo-Marine Letters 12, 88-95.

García-Hernández, M., López-Garrido, A.C., Rivas, P., Sanz de Galdeano, C., Vera, J.A., 1980. Mesozoic palaeogeographic evolution of the External Zones of the Betic Cordillera. Geologie en Mijnbouw 59, 155-168.

Gennari, G., Spezzaferri, S., Comas, M.C., Rüggeberg, A., Lopez-Rodriguez, C., Pinheiro, L.M., 2013. Sedimentary sources of the mud-breccia and mud volcanic activity in the Western Alboran Basin. Marine Geology 339, 83-95.

Gibert, L., Scott, G.R., Montoya, P., Ruiz-Sánchez, F.J., Morales, J., Luque, L., Abella, J., Lería, M., 2013. Evidence for an African-Iberian mammal dispersal during the pre-evaporitic Messinian. Geology 41, 691-694.

Gigliuto, L.G., Ouazani-Touhami, A., Puglisi, D., Puglisi, G., Zaghloul, M.N., 2004. Petrography and geochemistry of granitoid pebbles from the Oligocene-Miocene deposits of the internal Rifian chain Morocco; a possible new hypothesis of provenance and paleogeographical implications. Geologica Carpathica 55, 261-272.

Giraldo, C., Hermoza, W., 2013. Neogene Gravity-Driven Deformations around Gibraltar Arch Prior to the Messinian Salinity Crisis, AAPG European Regional Conference \& Exhibition, Barcelona, Abstract Book

Govers, R., Wortel, M.J.R., 2005. Lithosphere tearing at STEP faults: response to edges of subduction zones, Earth and Planetary Sciences Letters 236, 505-523.

Gueguen, E., Doglioni, C., Fernàndez, M., 1998. On the post-25 Ma geodynamic evolution of the western Mediterranean. Tectonophysics 298, 259-269.

Guerrera, F., Martín-Algarra, A., Perrone, V., 1993. Late Oligocene-Miocene syn-/-late-orogenic successions in Western and Central Mediterranean Chains from the Betic Cordillera to the Southern Apennines. Terra Nova 5, 525-544.

Guerrera, F., Martín-Algarra, A., Martín-Martín, M., 2012. Tectono-sedimentary evolution of the 'Numidian Formation' and Lateral Facies (southern branch of the western Tethys): constraints for central-western Mediterranean geodynamics. Terra Nova 24, 34-41.

Gutscher, M.A., Malod, J., Réhault, J.P., Contrucci, I., Klingelhoefer, F., Mendes-Victor, L., Spakman, W., 2002. Evidence for active subduction beneath Gibraltar. Geology 30, 1071-1074.

Hanne, D., White, N., Lonergan, L., 2003. Subsidence analyses from the Betic Cordillera, southeast Spain. Basin Research 15, 1-21.

Hardenbol, J., Thierry, J., Farley, M.B., Jacquin, T., de Graciansky, P.C., Vail, P., 1998. Mesozoic and Cenozoic sequence chronostratigraphic framework of European basins, in: P.C. Graciansky, et al. (Eds), Mesozoic and Cenozoic Sequence Stratigraphy of European Basins, SEPM Special Publication 60, 3-13, charts 1-8. 
Hernández-Molina, F.J., Serra, N., Stow, D.V., Llave, E., Ercilla, G., Van Rooij, D., 2011. Alongslope oceanographic processes and sedimentary products around the Iberian margin. Geo-Marine Letters 31, 315-341.

Hidas, K., Booth-Rea, G., Garrido, C.J., Martínez-Martínez, J.M., Padrón-Navarta, J.A., Konc, Z., Giaconia, F., Frets, E., Marchesi, C., 2013. Backarc basin inversion and subcontinental mantle emplacement in the crust: kilometre-scale folding and shearing at the base of the proto-Alborán lithospheric mantle (Betic Cordillera, southern Spain). Journal of the Geological Society 170, 47-55.

Hilgen, F.J., Kuiper, K.F.., Krijgsman, W., Snel, E., van der Laan, E., 2007. Astronomical tuning as the basis for high resolution chronostratigraphy: the intricate history of the Messinian Salinity Crisis. Stratigraphy, 4, 231-238.

Hlila, R., Chalouan, A., El Kadiri, K., Sanz de Galdeano, C., Martín-Pérez, J.A., Serrano, F., LópezGarrido, A.C., Maaté, A., Guerra-Merchán, A., 2008. New stratigraphic data of the Oligo-Miocene transgressive cover of the Ghomarides Units (northern internal Rif, Morocco): implications on tectono-sedimentary evolution. Revista de la Sociedad Geologica de Espana 21, 59-71.

Hsü, K., Ryan, W.B.F., Cita, M.B., 1973. Late Miocene Dessication of the Mediterranean. Nature 242, 240-244.

Hurford, A.J., Platt, J.P., Carter, A., 1999. Fission-track analysis of samples from the Alboran sea basement. Proceeding of the Ocean Drilling Program, Scientific Results 161, 295-300.

Iribarren, L., Vergés, J., Camurri, F., Fullea, J., Fernàndez, M., 2007. The structure of the AtlanticMediterranean transition zone from the Alboran Sea to the Horseshoe Abyssal Plain (Iberia-Africa plate boundary). Marine Geology 243, 97-119.

Iribarren, L., Vergés, J., Fernàndez, M., 2009. Sediment supply from the Betic-Rif orogen to basins through Neogene. Tectonophysics 475, 68-84.

Ismail-Zadeh, A., Matenco, L., Radulian, M., Cloetingh, S., Panza, G., 2012. Geodynamics and intermediate-depth seismicity in Vrancea (the south-eastern Carpathians): Current state-of-the art. Tectonophysics 530-531, 50-79.

Jabaloy, A., Galindo-Zaldívar, J., González-Lodeiro, F., 1992. The Mecina Extensional System: Its relation with the post-Aquitanian piggy-back Basins and the paleostresses evolution (Betic Cordilleras, Spain). Geo-Marine Letters 12, 96-103.

Jabaloy, A., Galindo-Zaldívar, J., González-Lodeiro, F., 1993. The Alpujárride-Nevado-Filábride extensional shear zone, Betic Cordillera, SE Spain. Journal of Structural Geology 15, 555-569.

Johnson, C., Harbury, N., Hurford, A.J., 1997. The role of extension in the Miocene denudation of the Nevado-Filabride Complex, Betic Cordillera (SE Spain). Tectonics 16, 189-204.

Jolivet, L., Faccenna, C., Goffé, B., Mattei, M., Rossetti, F., Brunet, C., Storti, F., Funiciello, R., Cadet, J.P., Parra, T., 1998. Mid-crustal shear zones in post-orogenic extension: the northern Tyrrhenian Sea case. J. Geophys. Res. 103, 12123-12160.

Jolivet, L., Faccenna, C., 2000. Mediterranean extension and the Africa-Eurasia collision. Tectonics 19, 1095-1106. 
Jolivet, L., Faccenna, C., Goffé, B., Burov, E., Agard, P., 2003. Subduction tectonics and exhumation of high-pressure metamorphic rocks in the Mediterranean orogens. American Journal of Science 303, 353-409.

Jolivet, L., Famin, V., Mehl, C., Parra, T., Aubourg, C., Hébert, R., Philippot, P., 2004. Strain localization during crustal-scale boudinage to form extensional metamorphic domes in the Aegean Sea. Geol. Soc. Am. Spec. Pap. 380, 185-210.

Jolivet, L., Augier, R., Robin, C., Suc, J.P., Rouchy, J.M., 2006. Lithospheric-scale geodynamic context of the Messinian salinity crisis. Sedimentary Geology 188-189, 9-33.

Jolivet, L., Augier, R., Faccenna, C., Negro, F., Rimmele, G., Agard, P., Robin, C., Rossetti, F., Crespo-Blanc, A., 2008. Subduction, convergence and the mode of backarc extension in the Mediterranean region. Bull. Soc. géol. Fr 179, 525-550.

Jolivet, L., Faccenna, C., Piromallo, C., 2009. From mantle to crust: Stretching the Mediterranean. Earth and Planetary Science Letters 285, 198-209.

Jolivet, L., Faccenna, C., Huet, B., Labrousse, L., Le Pourhiet, L., Lacombe, O., Lecomte, E., Burov, E,, Denèle, Y., Brun, J-P., Philippon, M., Paul, A., Salaün, G., Karabulut, H., Piromallo, C., Monié, P., Gueydan, F., Okay, A. I., Oberhänsli, R., Pourteau, A., Augier, R., Gadenne, L., Driussi, O., 2013. Aegean tectonics: Strain localisation, slab tearing and trench retreat. Tectonophysics 597-598, 1-33.

Jurado, M.J., Comas, M.C., 1992. Well log interpretation and seismic character of the cenozoic sequence in the northern Alboran Sea. Geo-Marine Letters 12, 129-136.

Kelley, S.P., Platt, J.P., 1999. Ar-Ar dating of biotite and muscovite from Alboran basement samples, Site 976. Proceedings of the Ocean Drilling Program, Scientific Results 161, 301-306.

Krijgsman, W., Langereis, C.G., Zachariasse, W.J., Boccaletti, M., Moratti, G., Gelati, R., Iaccarino, S., Papani, G., Villa, G., 1999. Late Neogene evolution of the Taza-Guercif Basin (Rifian Corridor, Morocco) and implications for the Messinian salinity crisis. Marine Geology 153, 147-160.

Kuo, L.C., Mountfield, R.A., Chevalier, Y.M., Haddad, G.A., Weinzapfel, A.C., Strickland, M.O., 2002. Petroleum systems and exploration potential of the western Alboran Basin. AAPG International Conference, El Cairo, Abstract Book.

Lacombe, O., Jolivet, L., 2005. Structural and kinematic relationships between Corsica and the Pyrenees-Provence domain at the time of the Pyrenean orogeny. Tectonics 24.

Le Pourhiet, L., Huet, B., May, D.A., Labrousse, L., Jolivet, L., 2012. Kinematic interpretation of the 3D shapes of metamorphic core complexes. Geochemistry Geophysics Geosystems 13, Q09002.

Levander, A., Bezada, M.J., Niu, F., Humphreys, E.D., Palomeras, I., Thurner, S.M., Masy, J., Schmitz, M., Gallart, J., Carbonell, R., Miller, M.S., 2014. Subduction-driven recycling of continental margin lithosphere. Nature 515, 253-U219.

Lonergan, L., Platt, J.P., 1995. The Malaguide-Alpujarride boundary: a major extensional contact in the Internal Zone of the eastern Betic Cordillera, SE Spain. Journal of Structural Geology 17, 16551671.

Lonergan, L., White, N., 1997. Origin of the Betic-Rif mountain belt. Tectonics 16, 504-522. 
López-Garrido, A.C., Sanz de Galdeano, C., 1999. Neogene sedimentation and tectono-eustatic control of the Malaga Basin, South Spain. Journal of Petroleum Geology 22, 81-96.

López Sánchez-Vizcaíno, V., Rubatto, D., Gómez-Pugnaire, M.T., Trommsdorff, V., Müntener, O., 2001. Middle Miocene high-pressure metamorphism and fast exhumation of the Nevado-Filábride complex, SE Spain. Terra Nova 13, 327-332.

Lourens, L.J., Hilgen, F.J., Laskar, J., Shackleton, N.J., Wilson, D., 2004. The Neogene period. In: Gradstein, F.M., Ogg, J.G., Smith, A.G. (Eds.), A geological Time Scale 2004. Cambridge University Press, Cambridge, pp. 409-440.

Maaté, A., Martín-Algarra, A., Martín-Martín, M., Serra-Kiel, J., 2000. Nouvelles données sur le Paléocène-Éocène des zones internes bético-rifaines. Geobios 33, 409-418.

Maldonado, A., Campillo, A.C., Mauffret, A., Alonso, B., Woodside, J., Campos, J., 1992. Alboran Sea Late Cenozoic Tectonic and Stratigraphic Evolution. Geo-Marine Letters 12, 179-186.

Maldonado, A., Somoza, L., Pallarés, L., 1999. The Betic orogen and the Iberian-African boundary in the Gulf of Cadiz: geological evolution (central North Atlantic). Marine Geology 155, 9-43.

Malinverno, A., Ryan, W.B.F., 1986. Extension in the Tyrrhenian Sea and shortening in the Apennines as result of arc migration driven by sinking of the lithosphere. Tectonics 5, 227-245.

Mancilla, F. de L., Stich, D., Berrocoso, M., Martín, R., Morales, J., Fernandez-Ros, A., Páez, R., Pérez-Peña, A., 2013. Delamination in the Betic Range: Deep structure, seismicity, and GPS motion. Geology 41, 307-310.

Martín, J.M., Braga, J.C., Betzler, C., 2001. The Messinian Guadalhorce corridor: the last northern, Atlantic-Mediterranean gateway. Terra Nova 13, 418-424.

Martín-Martín, M., Martín-Rojas, I., Caracuel, J.E., Estévez-Rubio, A., Algarra, A.M., Sandoval, J., 2006. Tectonic framework and extensional pattern of the Malaguide Complex from Sierra Espuña (Internal Betic Zone) during Jurassic-Cretaceous: implications for the Westernmost Tethys geodynamic evolution. International Journal of Earth Sciences 95, 815-826.

Martínez del Olmo, W., Comas, M.C., 2008. Arquitectura sísmica, olistostromas y fallas extensionales en el norte de la cuenca oeste del Mar de Albrán. Revista de la Sociedad Geologica de Espana 21, 151167.

Martínez del Olmo, W., 2011. El messiniense en el golfo de valencia y el mar de Alboran: implicaciones paleogeograficas y paleoceanograficas. Revista de la Sociedad Geológica de España 24(3-4), 237-257.

Martínez-García, P., Soto, J.I., Comas, M., 2011. Recent structures in the Alboran Ridge and Yusuf fault zones based on swath bathymetry and sub-bottom profiling: evidence of active tectonics. GeoMarine Letters 31, 19-36.

Martínez-García, P., Comas, M., Soto, J.I., Lonergan, L., Watts, A.B., 2013. Strike-slip tectonics and basin inversion in the Western Mediterranean: the Post-Messinian evolution of the Alboran Sea. Basin Research 25, 361-387.

Martínez-Martínez, J.M., Azañón, J.M., 1997. Mode of extensional tectonics in the southeastern 
Betics (SE Spain): Implications for the tectonic evolution of the peri-Alboran orogenic system. Tectonics 16, 205-225.

Martínez-Martínez, J.M., Soto, J.I., Balanyá, J.C., 2002a. Orthogonal folding of extensional detachments: Structure and origin of the Sierra Nevada elongated dome (Betics, SE Spain). Tectonics 21, TC001283.

Martínez-Martínez, J.M., Azañón, J.M., 2002b. Orthogonal extension in the hinterland of the Gibraltar Arc (Betics, SE Spain), in: Rosenbaum, G., Lister, G.S. (Eds.), Reconstruction of the evolution of the Alpine-Himalayan Orogen, pp. 3-22.

Matenco, L., Bertotti, G., Leever, K., Cloetingh, S., Schmid, S.M., Tărăpoancă, M., Dinu, C., 2007. Large-scale deformation in a locked collisional boundary: Interplay between subsidence and uplift, intraplate stress, and inherited lithospheric structure in the late stage of the SE Carpathians evolution. Tectonics 26, TC4011.

Mattei, M., Cifelli, F., Rojas, I.M., Crespo-Blanc, A., Comas, M.C., Faccenna, C., Porreca, M., 2006. Neogene tectonic evolution of the Gibraltar Arc: New paleomagnetic constrains from the Betic chain. Earth and Planetary Science Letters 250, 522-540.

Mauffret, A., Maldonado, A., Campillo, A.C., 1992. Tectonic framework of the eastern Alboran and western Algerian Basins, western Mediterranean. Geo-Marine Letters 12, 104-110.

Mauffret, A., Ammar, A., Gorini, C., Jabour, N., 2007. The Alboran Sea (Western Mediterranean) revisited with a view from the Moroccan Margin. Terra Nova 19, 195-203.

Maury, R.C., Fourcade, S., Coulon, C., El Azzouzi, M., Bellon, H., Coutelle, A., Ouabadi, A., Semroud, B., Megartsi, M., Cotten, J., Belanteur, Q., Louni-Hacini, A., Piqué, A., Capdevila, R., Hernandez, J., Réhault, J.P., 2000. Post-collisional Neogene magmatism of the Mediterranean Maghreb margin: a consequence of slab breakoff. Comptes Rendus Acad. Sci. Ser II-A 331, 159-173.

Medialdea, T., Vegas, R., Somoza, L., Vázquez, J. T., Maldonado, A., Díaz-del-Río, V., Maestro, A., Córdoba, D., Fernández-Puga, M.C., 2004. Structure and evolution of the "Olistostrome" complex of the Gibraltar Arc in the Gulf of Cádiz (eastern Central Atlantic): evidence from two long seismic cross-sections. Marine Geology 209, 173-198.

Meijninger, B.M.L., Vissers, R.L.M., 2006. Miocene extensional basin development in the Betic Cordillera, SE Spain revealed through analysis of the Alhama de Murcia and Crevillente Faults. Basin Research 18, 547-571.

Meulenkamp, J.E., Sissingh, W., 2003. Tertiary palaeogeography and tectonostratigraphic evolution of the Northern and Southern Peri-Tethys platforms and the intermediate domains of the AfricanEurasian convergent plate boundary zone. Palaeogeography, Palaeoclimatology, Palaeoecology 196, 209-228.

Michard, A., Chalouan, A., Feinberg, H., Goffé, B., Montigny, R., 2002. How does the Alpine belt end between Spain and Morocco? Bull. Soc. géol. Fr 173, 3-15.

Michard, A., Negro, F., Saddiqi, O., Bouybaouene, M.L., Chalouan, A., Montigny, R., Goffé, B., 2006. Pressure-temperature-time constraints on the Maghrebide mountain building: evidence from the Rif-Betic transect (Morocco, Spain), Algerian correlations, and geodynamic implications. C. R. Geosciences 338, 92-114. 
Michard, A., Mokhtari, A., Chalouan, A., Saddiqi, O., Rossi, P., Rjimati, E.C., 2014. New ophiolite slivers in the External Rif belt, and tentative restoration of a dual Tethyan suture in the western Maghrebides. Bull Soc géol France 185, 313-328.

Mitchum, R., Vail, P., 1977. Seismic stratigraphy and global changes of sea-level, part 7: Seismic Stratigraphic Interpretation Procedure, in: Payton, C.E., (Ed), Seismic Stratigraphy - Applications to hydrocarbon exploration, American Association Petroleum Geologist Memoir 26.

Monié, P., Chopin, C., 1991. 40Ar-39Ar ages through high-pressure low-temperature metamorphism in the Western Alps. Eur. J. Mineral. 2, 343-361.

Monié, P., Torres-Roldán, R.L., García-Casco, A., 1994. Cooling and exhumation of the Western Betic Cordilleras, 40Ar/39Ar thermochronological constraints on a collapsed terrane. Tectonophysics 238, 353-379.

Morel, J.L., 1987. Evolution récente de l'orogène rifain et de son avant-pays depuis la fin de la mise en place des nappes (Rif-Maroc). Ph.D Thesis, Université de Paris-Sud, Orsay, 584p.

Morley, C.K., 1992. Notes on Neogene basin history of the Western Alboran Sea and its implications for the tectonic evolution of the Rif-Betic orogenic belt. Journal of African Earth Sciences 14, 57-65.

Morley, C.K., 1993. Discussion of origins of hinterland basins to the Rif-Betic Cordillera and Carpathians. Tectonophysics 226, 359-376.

Mountfield, R.A., Chevalier, Y.M., Haddad, G.A., Kuo, L.C., Weinzapfel, A.C., 2002. Petroleum systems and exploration potential of the western Alboran Basin. Marrakech International Oil and Gas Conference, Abstract Book.

Negro, F., Beyssac, O., Goffé, B., Saddiqi, O., Bouybaouène, M.L., 2006. Thermal structure of the Alboran Domain in the Rif (northern Morocco) and the Western Betics (southern Spain). Constraints from Raman spectroscopy of carbonaceous material. Journal of Metamorphic Geology 24, 309-327.

Negro, F., de Sigoyer, J., Goffé, B., Saddiqi, O., Villa, I.M., 2008. Tectonic evolution of the Betic-Rif arc: New constraints from (40)Ar/(39)Ar dating on white micas in the Temsamane units (External Rif, northern Morocco). Lithos 106, 93-109.

Nocquet, J.M., 2012. Present-day kinematics of the Mediterranean: A comprehensive overview of GPS results. Tectonophysics 579, 220-242.

Osmundsen, P.T., Andersen, T.B., 1994. Caledonian compressional and late-orogenic extensional deformation in the Staveneset area, Sunnfjord, Western Norway. Journal of Structural Geology 16, $1385-1401$.

Ott d'Estevou, P., Montenat, C., 1990. Le bassin de Sorbas-Tabernas, in : Montenat, C . (Ed) Les bassins néogènes du domaine bétique orientale (Espagne). Documents et Travaux IGAL 12-13, 101128.

Palomino, D., Vázquez, J.T., Ercilla, G., Alonso, B., López-González, N., Díaz-del-Río, V., 2011. Interaction between seabed morphology and water masses around the seamounts on the Motril Marginal Plateau (Alboran Sea, Western Mediterranean). Geo-Marine Letters 31, 465-479.

Pedrera, A., Ruiz-Constán, A., Galindo-Zaldívar, J., Chalouan, A., Sanz de Galdeano, C., Marín- 
Lechado, C., Ruano, P., Benmakhlouf, M., Akil, M., López-Garrido, A.C., Chabli, A., Ahmamou, M., González-Castillo, L., 2011. Is there an active subduction beneath the Gibraltar orogenic arc? Constraints from Pliocene to present-day stress field. Journal of Geodynamics 52, 83-96.

Pérez-Belzuz, F., Alonso, B., Ercilla, G., 1997. History of mud diapirism and trigger mechanisms in the Western Alboran Sea. Tectonophysics 282, 399-422.

Platt, J.P., Vissers, R.L.M., 1989. Extensional collapse of thickened continental lithosphere: A working hipothesis for the Alboran Sea and Gibraltar Arc. Geology 17, 540-543.

Platt, J.P., Whitehouse, M.J., 1999. Early Miocene high-temperature metamorphism and rapid exhumation in the Betic Cordillera (Spain): evidence from U-Pb zircon ages. Earth and Planetary Science Letters 171, 591-605.

Platt, J.P., Allerton, S., Kirker, A.I., Mandeville, C., Mayfield, A., Platzman, E., Rimi, A., 2003a. The ultimate arc: Differential displacement, oroclinal bending, and vertical axis rotation in the External Betic-Rif arc. Tectonics 22, TC1017.

Platt, J.P., Whitehouse, M.J., Kelley, S.P., Carter, A., Hollick, L., 2003b. Simultaneous extensional exhumation across the Alboran Basin: Implications for the causes of late orogenic extension. Geology $31,251-254$.

Platt, J.P., Kelley, S.P., Carter, A., Orozco, M., 2005. Timing of tectonic events in the Alpujarride Complex, Betic Cordillera, southern Spain. Journal of the Geological Society London 162, 1-12.

Platt, J.P., Anczkiewicz, R., Soto, J.I., Kelley, S.P., Thirlwall, M., 2006. Early Miocene continental subduction and rapid exhumation in the western Mediterranean. Geology 34, 981-984.

Platt, J.P., Behr, W.M., Johanesen, K., Williams, J.R., 2013. The Betic-Rif Arc and Its Orogenic Hinterland: A Review. Annual Review of Earth and Planetary Sciences 41, 313-357.

Platzman, E., Platt, J.P., 2004. Kinematics of a twisted core complex: Oblique axis rotation in an extended terrane (Betic Cordillera, southern Spain). Tectonics 23, TC6010.

Précigout, J., Gueydan, F., Garrido, C.J., Cogné, N., Booth-Rea, G., 2013. Deformation and exhumation of the Ronda peridotite (Spain). Tectonics 31, 1-15.

Puga, E., Nieto, J.M., Díaz De Federico, A., 2000. Contrasting P-T Paths in eclogites of the Betic Ophiolitic Association, Mulhacen Complex, Southeastern Spain. The Canadian Mineralogist 38, 1137 1161.

Puglisi, D., 2008. Oligocene-Miocene sandstone suites from the Gibraltar and Calabria-Peloritani Arcs: provenance changes and paleogeographic implications. Geologica Carpathica 59, 525-535.

Raffi, I., Backman, J., Fornaciari, E., Pälike, H., Rio, D., Lourens, L., Hilgen, F., 2006. A review of calcareous nannofossil astrobiochronology encompassing the past 25 million years. Quaternary Science Reviews 25, 3113-3137.

Réhault, J.-P., Boillot, G., Mauffret, A., 1984. The Western Mediterranean Basin geological evolution. Marine Geology 55, 447-477.

Rodríguez-Fernández, J., Comas, M.C., Soría, J., Martín-Pérez, J.A., Soto, J.I., 1999. The sedimentary 
record of the Alboran basin: an attempt at sedimentary sequence correlation and subsidence analysis. Proceeding of the Ocean Drilling Program, Scientific Results 161, 69-76.

Rodríguez-Fernández, J., Sanz de Galdeano, C., 2006. Late orogenic intramontane basin development: the Granada basin, Betics (southern Spain). Basin Research 18, 85-102.

Rodríguez-Fernández, J., Azor, A., Azañón, J.M., 2011. The Betic Intramontane Basins (SE Spain): Stratigraphy, Subsidence, and Tectonic History, in Tectonics of Sedimentary Basins. John Wiley \& Sons, Ltd, pp. 461-479.

Rosenbaum, G., Lister, G.S., Duboz, C., 2002a. Reconstruction of the tectonic evolution of the western Mediterranean since the Oligocene. Journal of the Virtual Explorer 08, 6, doi: 10.3809/jvirtex.2002.00053.

Rosenbaum, G., Lister, G.S., Duboz, C., 2002b. Relative motions of Africa, Iberia and Europe during Alpine orogeny. Tectonophysics 359, 117-129.

Rossetti, F., Faccenna, C., Crespo-Blanc, A., 2005. Structural and kinematic constraints to the exhumation of the Alpujarride Complex (Central Betic Cordillera, Spain). Journal of Structural Geology 27, 199-216.

Royden, L.H., 1993. Evolution of retreating subduction boundaries formed during continental collision. Tectonics 12, 629-638.

Ruiz-Constán, A., Galindo-Zaldívar, J., Pedrera, A., Célérier, B., Marín-Lechado, C., 2011. Stress distribution at the transition from subduction to continental collision (northwestern and central Betic Cordillera). Geochem. Geophys. Geosyst. 12, Q12002.

Sánchez-Gómez, M., Azañón, J.M., García-Dueñas, V., Soto, J.I., 1999. Correlation between the metamorphic rocks recovered from Site 976 and the Alpujarride rocks of the Western Betics. Proceeding of the Ocean Drilling Program, Scientific Results 161, 307-317.

Sánchez-Gomez, M., Balanyá, J.C., Garcia-Dueñas, V., Azañón, J.M., 2002. Intracrustal tectonic evolution of large lithosphere mantle slabs in the western end of the Mediterranean orogen (Gibraltar arc). Journal of the Virtual Explorer 8(2).

Sanz de Galdeano, C., Vera, J.A., 1992. Stratigraphic record and palaeogeographical context of the Neogene basins in the Betic Cordillera, Spain. Basin Research 4, 21-36.

Sautkin, A., Talukder, A.R., Comas, M.C., Soto, J.I., Alekseev, A., 2003. Mud volcanoes in the Alboran Sea: evidence from micropaleontological and geophysical data. Marine Geology 195, 237261.

Schettino, A., Turco, E., 2006. Plate kinematics of the Western Mediterranean region during the Oligocene and Early Miocene. Geophysical Journal International 166, 1398-1423.

Seber, D., Barazangi, M., Ibenbrahim, A., Demnati, A., 1996. Geophysical evidence for lithospheric delamination beneath the Alboran Sea and Rif-Betic mountains. Nature 379, 785-790.

Séranne, M., Séguret, M., 1987. The Devonian Basins of western Norway: tectonics and kinematics of an extending crust, in Continental Extensional Tectonics, vol. Special Publication 28, edited by M.P. Coward, J.F. Dewey and P.L. Hancock, pp. 37-48, Geological Society of London, London, 1987. 
Serpelloni, E., Vannucci, G., Pondrelli, P., Argnani, A., Casula, G., Anzidei, M., Baldi, B., Gasperini, P., 2007. Kinematics of the Western Africa-Eurasia plate boundary from focal mechanisms and GPS data. Geophysical Journal International 169, 1180-1200.

Serrano, F., Guerra-Merchán, A., El Kadiri, K., Sanz de Galdeano, C., López-Garrido, A.C., MartínMartín, M., Hlila, R., 2007. Tectono-sedimentary setting of the Oligocene-early Miocene deposits on the Betic-Rifian Internal Zone (Spain and Morocco). Geobios 40, 191-205.

Sissingh, W., 2008. Punctuated Neogene tectonics and stratigraphy of the African-Iberian plateboundary zone: concurrent development of Betic-Rif basins (southern Spain, northern Morocco). Netherlands Journal of Geosciences 87, 241-289.

Somoza, L., Medialdea, T., León, R., Ercilla, G., Vázquez, J.T., Farran, M., Hernández-Molina, J., González, J., Juan, C., Fernández-Puga, M.C., 2012. Structure of mud volcano systems and pockmarks in the region of the Ceuta Contourite Depositional System (Western Alborán Sea). Marine Geology 332-334, 4-26.

Soria, J.M., 1993. La sedimentacion néogena entre Sierra Arana y el Río Guadiana Menor (Cordillera Bética central). Evolucion desde un margen continental hasta una cuenca intramontañosa. Ph.D. Thesis, University of Granada, Granada, Spain, 400 p.

Soto, J.I., Comas, M., Rubio, J.D.L.L., 1996. Espesor de sedimentos en la cuenca de Alborán mediante una conversión sísmica corregida. Geogaceta 20, 382-285.

Soto, J.I., Platt, J.P., 1999. Petrological and Structural Evolution of High-Grade Metamorphic Rocks from the floor of the Alboran Sea Basin, Western Mediterranean. Journal of Petrology 40, 21-60.

Soto, J.I., Platt, J.P., Sánchez-Gómez, M. Azañón, J.M., 1999. P-T evolution of the metamorphic basement of the Alboran Sea (Site 976) based on thermobarometry and structural observations, Proceeding of the Ocean Drilling Program, Scientific Results 161, 263-279.

Soto, J.I., Fernández-Ibáñez, F., Talukder, A., Martínez-García, P., 2010. Miocene shale tectonics in the Alboran Sea (western Mediterranean), in Wood, L. (Ed), Shale Tectonics: AAPG Memoir 93, 119144.

Spakman, W., Wortel, R., 2004. A tomographic view on Western Mediterranean Geodynamics, in: Cavazza, W., Roure, F., Spakman, W., Stampfli, G.M., Ziegler, P. (Eds.), The TRANSMED Atlas, The Mediterranean Region from Crust to Mantle, pp. 31-52.

Sternai, P., Jolivet, L., Menant, A., Gerya, T., 2014. Subduction and mantle flow driving surface deformation in the Aegean-Anatolian system. Earth and Planetary Science Letters 405, 110-118; dx.doi.org/110.1016/j.epsl.2014.1008.1023.

Stich, D., Serpelloni, E., Mancilla, F.d.L., Morales, J., 2006. Kinematics of the Iberia-Maghreb plate contact from seismic moment tensors and GPS observations. Tectonophysics 426, 295-317.

Suades, E., Crespo-Blanc, A., 2013. Gravitational dismantling of the Miocene mountain front of the Gibraltar Arc system deduced from the analysis of an olistostromic complex (western Betics). Geologica Acta 11, 215-229.

Talukder, A.R., Comas, M.C., Soto, J.I., 2003. Pliocene to Recent mud diapirism and related mud volcanoes in the Alboran Sea (Western Mediterranean). In: Maltman, A., Van Rensbergen, P., Morley, 
C., Cartwright, J. (Eds.), Mobilisation of Subsurface Sediments: Geological Society of London Special Publication, 216, pp. 443-459.

Thomas, M.F.H., Bodin, S., Redfern, J., Irving, D.H.B., 2010. A constrained African craton source for the Cenozoic Numidian Flysch: Implications for the palaeogeography of the western Mediterranean basin. Earth-Science Reviews 101, 1-23.

Thurner, S., Palomeras, I., Levander, A., Carbonell, R., Lee, C-T., 2014. Ongoing lithospheric removal in the western Mediterranean: Evidence from Ps receiver functions and thermobarometry of Neogene basalts (PICASSO project). Geochemistry, Geophysics, Geosystems 15, 1113-1127.

Tiliţă, M., Matenco, L., Dinu, C., Ionescu, L., Cloetingh, S., 2013. Understanding the kinematic evolution and genesis of a back-arc continental "sag" basin: The Neogene evolution of the Transylvanian Basin. Tectonophysics 602, 237-258.

Torres-Roldán, R.L., 1979. The tectonic subdivision of the Betic Zone (Betic Cordilleras, southern Spain); its significance and one possible geotectonic scenario for the westernmost Alpine Belt. American Journal of Science 279, 19-51.

Turner, S.P., Platt, J.P., George, R.M.M., Kelley, S.P., Pearson, D.G., Nowell, G.M., 1999. Magmatism Associated with Orogenic Collapse of the Betic-Alboran Domain, SE Spain. Journal of Petrology 40, 1011-1036.

Van Wagoner, J.C., Posamentier, H.W., Mitchum, R.M., Vail, P.R., Sarg, J.F., Loutit, T.S., Hardenbol, J., 1989. An overview of the fundamentals of sequence stratigraphy and key definitions, in: Wilgus, C.K., Hastings, B.S., Posamentier, H., Wagoner, V., J., Ross, C.A., Kendall, C.G. (Eds.), Sea-Level changes - An integrated Approach. Society of Economic Paleontologists, Mineralogists, Tulsa, Oklahoma, U.S.A.

Vázquez, M., Jabaloy, A., Barbero, L., Stuart, F.M., 2011. Deciphering tectonic- and erosion-driven exhumation of the Nevado-Filabride Complex (Betic Cordillera, Southern Spain) by low temperature thermochronology. Terra Nova 23, 257-263.

Vera, J.A., 2000. El Tercario de la Cordillera Bética: estado actual de conocimientos. Revista de la Sociedad Geologica de España 13, 345-373.

Vergés, J., Fernàndez, M., 2012. Tethys-Atlantic Interaction along the Iberia-Africa Plate Boundary: The Betic-Rif Orogenic System. Tectonophysics 579, 144-172.

Vissers, R.L.M., Platt, J.P., van der Wal, D., 1995. Late orogenic extension of the Betic Cordillera and the Alboran Domain: A lithospheric view. Tectonics 14, 786-803.

Warny, S.A., Bart, P.J., Suc, J.P., 2003. Timing and progression of climatic, tectonic and glacioeustatic influences on the Messinian Salinity Crisis. Palaeogeography, Palaeoclimatology, Palaeoecology 202, 59-66.

Watts, A.B., Platt, J.P., Buhl, P., 1993. Tectonic evolution of the Alboran Sea basin. Basin Research 5, 153-177.

Weijermars, R., Roep, T.B., Van den Eeckhout, B., Postma, G., Kleverlaan, K., 1985. Uplift history of a Betic fold nappe inferred from Neogene-Quaternary sedimentation and tectonics (in the Sierra Alhamilla and Almeria, Sorbas and Tabernas Basins of the Betic Cordilleras, SE Spain). Geol. Mijnb. 
64, 397-411.

Weinzapfel, A.C., Mountfield, R.A., Chevalier, Y.M., Kuo, L.C., Soofi, K.A., Haddad, G.A., Strickland, M.O., 2003. New insights into the hydrocarbon prospectivity of an undrilled mud diapir province, west Alboran Basin, Morocco-Spain. AAPG Annual Meeting, Abstract Book.

Wildi, W., 1983. La chaîne tello-rifaine (Algérie, Maroc, Tunisie): structure, stratigraphie et évolution du Trias au Miocène. Revue Géologie Dynamique et Géographie Physique 24, 201-297.

Willet, A., 1991. Marine geophysical investigations of the Alboran Sea. Ph.D Thesis, Oxford Univ., $160 \mathrm{pp}$.

Wortel, M.J.R., Spakman W., 2000. Subduction and slab detachment in the Mediterranean-Carpathian region. Science 290, 1910-1917.

Zaghloul, M.N., Gigliuto, L.G., Puglisi, D., Ouazani-Touhami, A., Belkaid, A., 2003. The OligoceneMiocene Ghomaride cover: a petro-sedimentary record of an early subsident stage related to the Alboran Sea rifting (Northern Internal Rif, Morocco). Geologica Carpathica 54, 93-105.

Zaghloul, M.N., Di Staso, A., Hlila, R., Perrone, V., Perrotta, S., 2010. The Oued Dayr Formation: first evidence of a new Miocene late-orogenic cycle on the Ghomaride complex (Internal Domains of the Rifian Maghrebian Chain, Morocco). Geodinamica Acta 23, 185-194.

\section{Figure captions:}

Figure 1: Structural maps of the southern margin of the western Mediterranean Sea representing the main tectonic units and the location of the Western Alboran Basin (WAB). GK: Greater Kabylide; LK: Lesser Kabylide. The inset map shows the location of the Apennines, Tellian, Rif and Betic fold and thrust belts in the western Mediterranean.

Figure 2: A. Geological map of the Alboran Sea area showing major tectonic features of the Betic and Rif mountain belts and the location of the deepest depocenter in yellow (from Irribaren et al., 2009). ODP sites 976 to 979, DSDP site 121, and all industrial wells are also located offshore (And G1 = Andalucía-G1; Alb A1 = Alborán-A1; And A1 = Andalucía-A1; El Jebha and Nador 1). $\mathrm{AR}=$ Alboran ridge; $\mathrm{AI}=$ Alboran Island; $\mathrm{EAB}=$ Eastern Alboran Basin; $\mathrm{SAB}=$ South Alboran Basin; WAB = western Alboran Basin; XB = Xauen bank; YF = Yusuf fault. Modified from Comas et al. $(1992,1999)$ and Martínez-García et al. $(2011,2013)$.

B. Map showing the location of the industrial (dark grey) and academic (light grey) seismic lines interpreted in the Western Alboran Basin. Blue lines (in two-way travel time and migrated depth), orange lines (in two-way travel time) represent the more recent $2 \mathrm{D}$ seismic acquisition (courtesy of ONHYM and ICM-CSIC Barcelona). The red transects are presented in this paper. List of industrial surveys: ALB-81, AM-74, AM-78, AM-79, AS-77, BRPM-80, EAS-74, ESCI-91, IZD-82, MO-75, SHL-75, TSH-83, CAB-01. List of academic surveys: ALHO-81, CONT-2010, CONR-88, GC-83, GC-90, ODP-95, MAB-2012, MAR-2011, MARG-2006, POLY-72, RAY-72, SAGAS-2010, SARAS-2012, TTR-2002, TYRO-91, WAT-91.

Figure 3: Geodynamic and tectonic context. 
A. Hypocenter of the earthquake beneath the Alboran Sea and surroundings for $\mathrm{M}>3$ (from http://www.ign.es/ign/layout/sismo.do). Two cross-sections, I and II, oriented NW-SE and SW-NE, respectively, show the relative position of the Western Alboran Basin above the sinking slab marked by the seismicity. See also Gutscher et al. (2002).

B. Crustal-scale geological cross-sections of the Alboran domain showing the overall tectonostratigraphic framework from the External zones to the Internal zones, above which the Alboran Sea basin developed. Modified from Sánchez-Gómez et al. (2002), Crespo-Blanc and Frizon de Lamotte (2006), and using the Moho depth of Thurner et al. (2014). The inset in the upper right corner is a schematic yet intelligible view of the location of the western Alboran Basin with respect to the subducted slab geometry.

Figure 4: Stratigraphic logs of Andalucía-G1 and El Jebha industrial wells drilled on the northern and southern sides of the western Alboran Basin, respectively. The ages of the sedimentary sequences are re-assessed based on their paleontological content (biomarkers are listed in the middle column). The seismic units in the right-hand columns are those defined by Chalouan $e t$ al. (1997) and Comas et al. (1999) compared to the seismic units described in this study.

Figure 5: Uninterpreted and interpreted seismic profiles offshore Spain showing the northeastern WAB architecture tied to the Andalucia-G1 well. A correlation is made between the depth migrated CAB01-102, 123, 104 and 125 seismic sections with the CAB01-121 (in two-way time depth) as published by Soto et al. (2010). Baselap, when the layout pattern is ambiguous, and onlap terminations are frequently identified along our seismic sequence boundaries. 8 seismic units (from SU1 to SU8) were identified in the basin. The seismo-stratigraphic framework and mapped reflectors discussed in the text are labelled and the colors are consistent in all the following figures. Location of the seismic section in Fig. 2B. P: Pliocene; M: Messinian; T: Tortonian; S: Serravallian; L: Langhian; V.E.: vertical exaggeration.

Figure 6: Uninterpreted and interpreted CAB01-150 seismic profiles offshore Morocco showing the southern WAB architecture tied to the El Jebha well. 7 seismic units, from SU1 to SU8, were in this part of the basin. Note that the seismo-facies defined as SU2 offshore Spain has not been identified. Location of the seismic section in Fig. 2B. P: Pliocene; M: Messinian; T: Tortonian; S-L: Serravallian- Langhian.

Figure 7: A. Depth migrated CAB01-102 seismic section offshore Spain, showing the northern WAB architecture and the main stratal terminations of the sedimentary infill (courtesy of ICM-CSIC Barcelona). B. Interpretation of the main seismic units (SU1 to SU8) identified in the basin. Location of the seismic section in Fig. 2B. V.E.: vertical exaggeration.

Figure 8: A. NNW-SSE regional seismic section offshore Morocco (CAB01-101), showing the western side of the WAB architecture and the main stratal terminations of the sedimentary infill (courtesy of ONHYM). B. Interpretation of the main seismic units (SU1 to SU8) identified in the basin. Location of the seismic section in Fig. 2B.

Figure 9: A. NNW-SSE seismic section offshore Morocco (CAB01-111), showing the central WAB architecture and the main stratal terminations of the sedimentary infill (courtesy of ONHYM). B. Interpretation of the main seismic units (SU1 to SU8) identified in the basin. Location of the seismic section in Fig.2B.

Figure 10: A. Regional SW-NE seismic section offshore Morocco (CAB01-132) crossing the WAB 
and showing the deep architecture of the basin and the main stratal terminations of the sedimentary infill (courtesy of ONHYM). B. Interpretation of the main seismic units (SU1 to SU8) identified in the basin. Location of the seismic section in Fig. 2B.

Figure 11: A. Regional SW-NE seismic section offshore Morocco (CAB01-140) crossing the WAB and showing the deep architecture of the basin and the main stratal terminations of the sedimentary infill (courtesy of ONHYM). B. Interpretation of the main seismic units (SU1 to SU8) identified in the basin. Location of the seismic section in Fig. 2B.

Figure 12: Zoom on the seismic attributes of seismic units 1, 2 and 3 and their respecting boundaries. Seismic profiles CAB01-125, CAB01-123 and CAB01-140 are displayed using the pseudorelief attribute developed by Kingdom Software ${ }^{\circledR}$ which enables better observation of the internal structure of each seismic unit revealed by the acoustic impedance jump. R1 to R4 refer to the reflectors defined in Figure 6.

Figure 13: A. Depth to basement map interpolated from the 2D seismic dataset (in second two-way travel time). This horizon is affected by many faults from the Alboran Ridge (AR) through the Xauen Bank (XB), up to the WAB floor. B to G. Isopach map of the seismic units identified from the Pre-rift sequence SU1 to the Upper Tortonian SU6 and their associated deformation.

Figure 14: Seismic facies of the SU1 unit on the western side of the WAB seen on dip seismic lines flattened at the top of Serravallian. To the north, the upper SU1b sequence exhibits internal imbricated thrusts that do not affect the Middle Miocene series onlapping the SU1. Toward the south, both SU1a and SU1b are progressively characterized by moderate to high amplitude, semi-continuous to continuous reflectors.

Figure 15: Onshore-offshore chronostratigraphic correlation from Spain to Morocco showing the main unconformities that affect the whole domain (based on Ott d'Estevou and Montenat, 1990; Sanz de Galdeano and Vera, 1992; Vera, 2000; Zaghloul et al., 2003; El Kadiri et al., 2005; Sissingh, 2008; Zaghloul et al., 2010; Rodríguez-Fernández, 2011; Suades and Crespo-Blanc, 2013), together with synthetic cross-sections showing the evolution of the western Alboran basin from late Oligocene (a) to the late Tortonian and the shift from extensional to contractional reorganization (d).

Figure 16: Paleogeographic maps of the southwestern Mediterranean region from the Early Oligocene to late Messinian displaying the main tectonic units and processes in the study area. The main geological structures, mostly compressive, are shown along with the location and successive deformation of the Flysch units, the volcanic events and the formation and development of the Western Alboran Basin. AR = Alboran ridge; $\mathrm{YF}=$ Yusuf fault.

Figure 17: Synthetic cross-sections of the Alboran domain showing the main tectonic units and exhumation processes over time. The cross-sections cross main structures perpendicularly from the south to the north including the north African subduction zone in the late Oligocene (A) or the Gibraltar arc represented by the Rif and Eastern Betics belts (B, C and D). In crosssection C, the top-to-the SW sense of shear of the extensional detachment between the Nevado-Filabrides and the Alpujarrides complexes is highlighted by two arrows in perspective.

Figure 18: Schematic three dimensional view and corresponding cross-sections of the westernmost Mediterranean region showing slab tearing and slab retreat following the slowing down of the 
African plate due to collision with Eurasia. The WAB is in yellow.

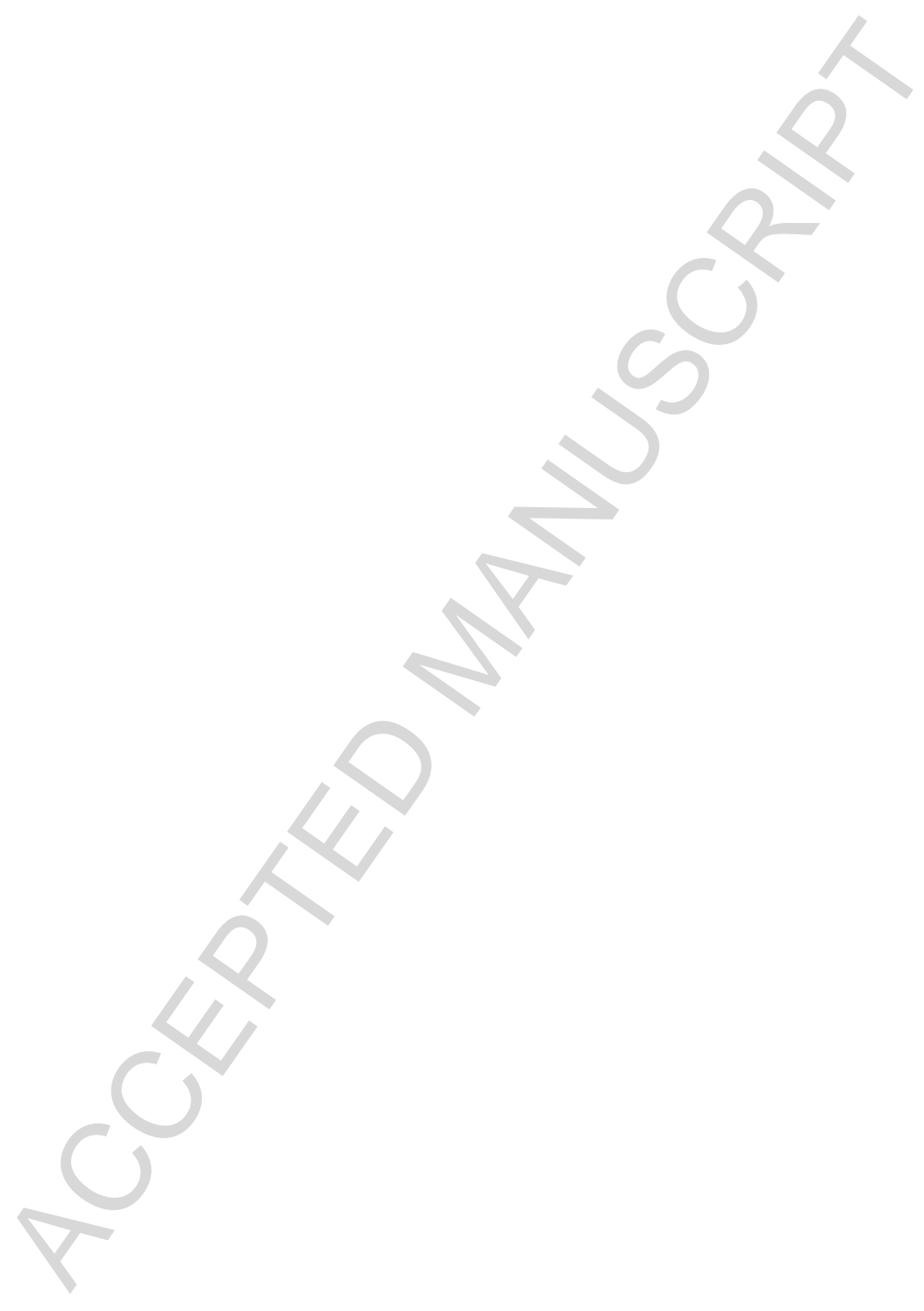




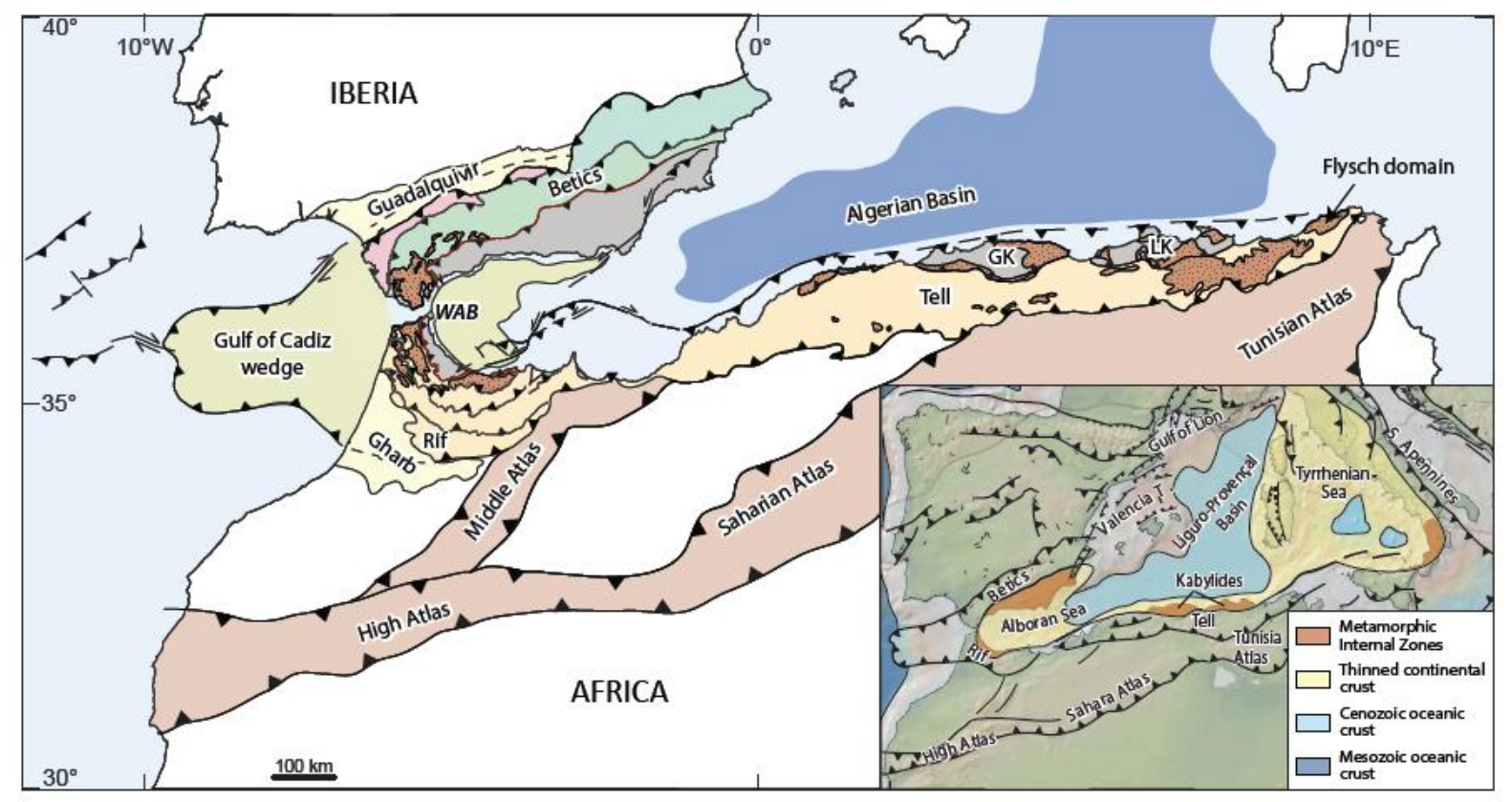

Figure 1 

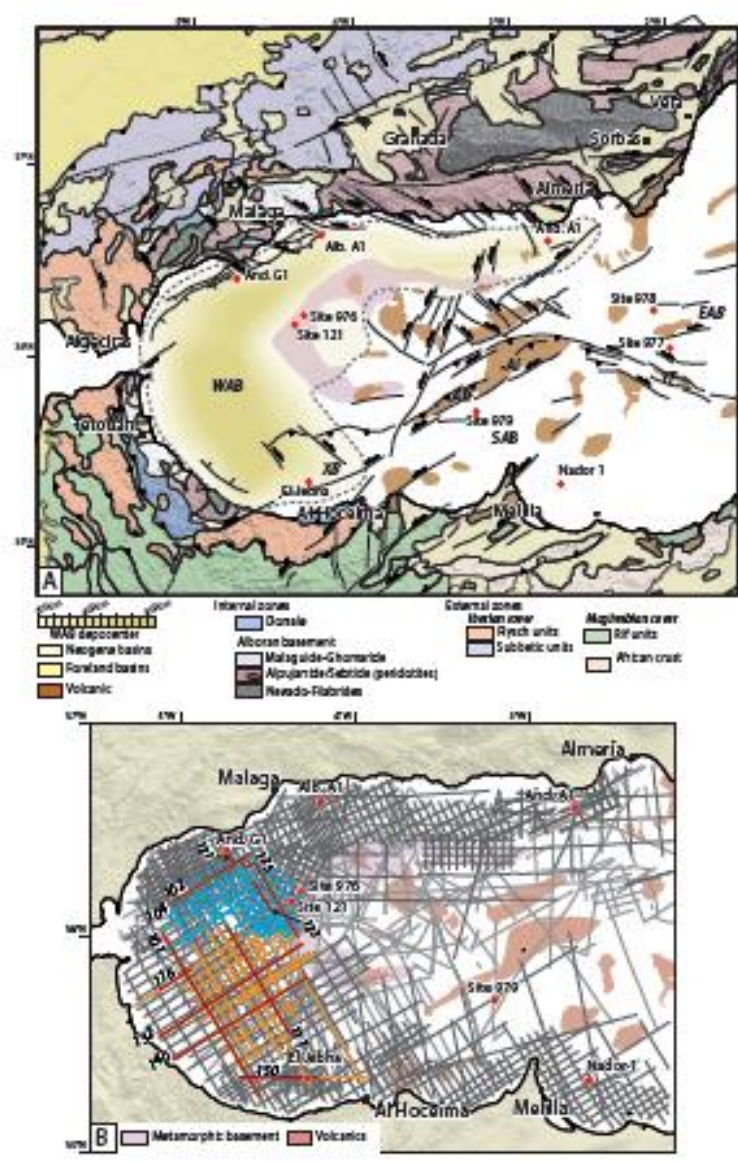

Figure 2 
A

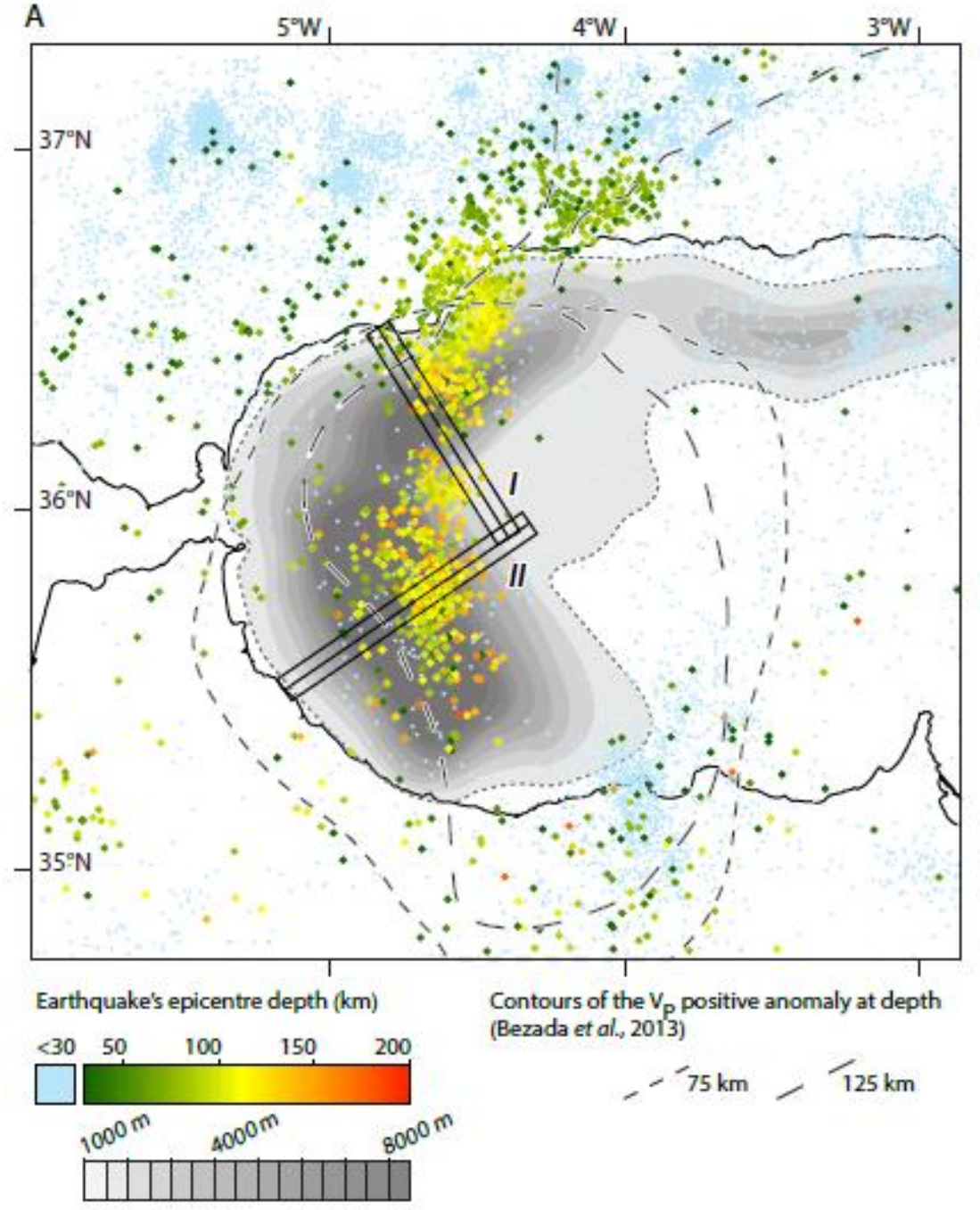

I.

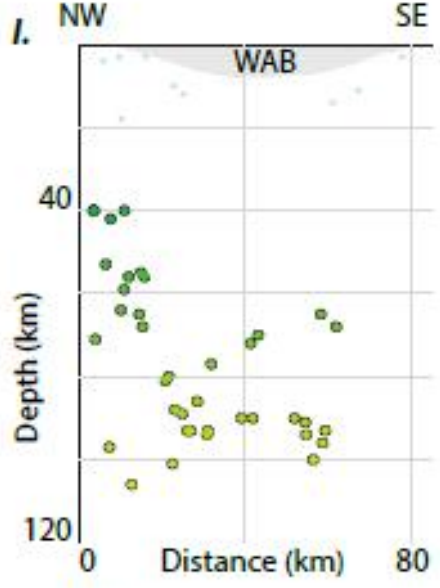

II. ${ }^{5}$

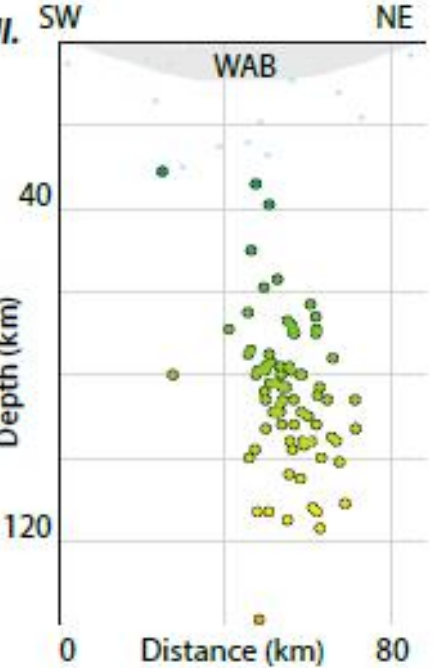

Figure 3 


\section{Andalucia-G1}

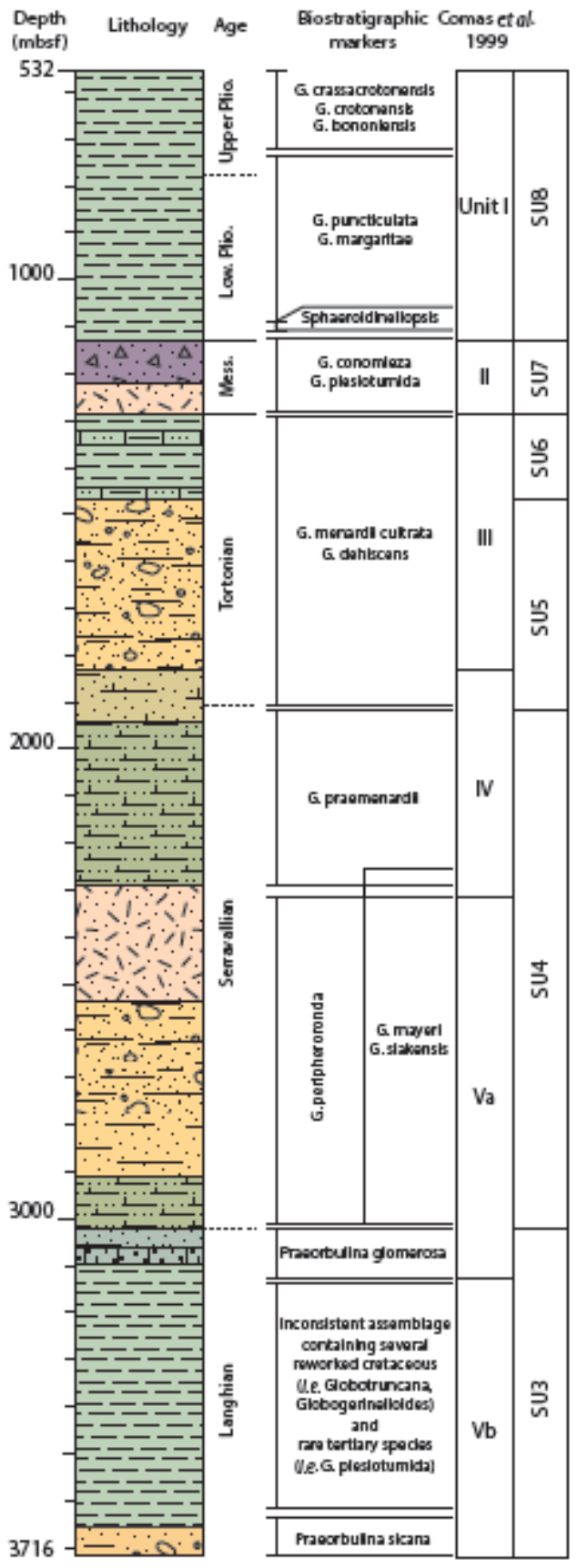

El Jebha

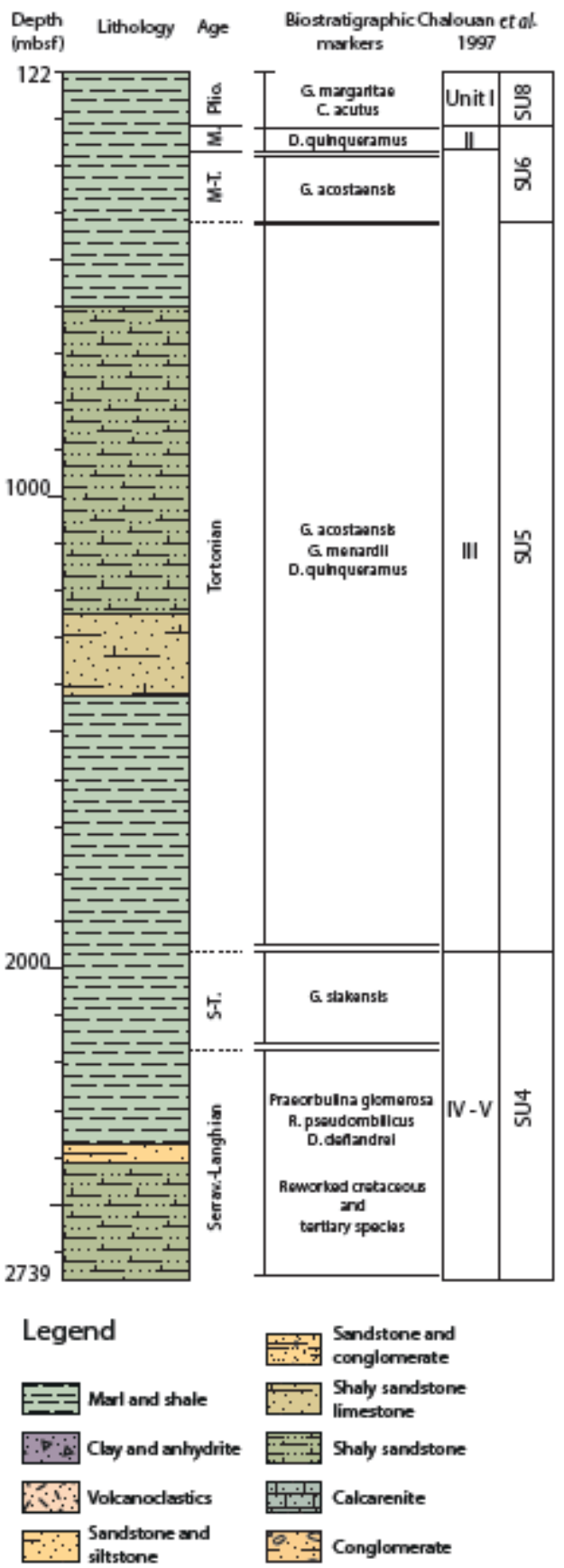

Figure 4 

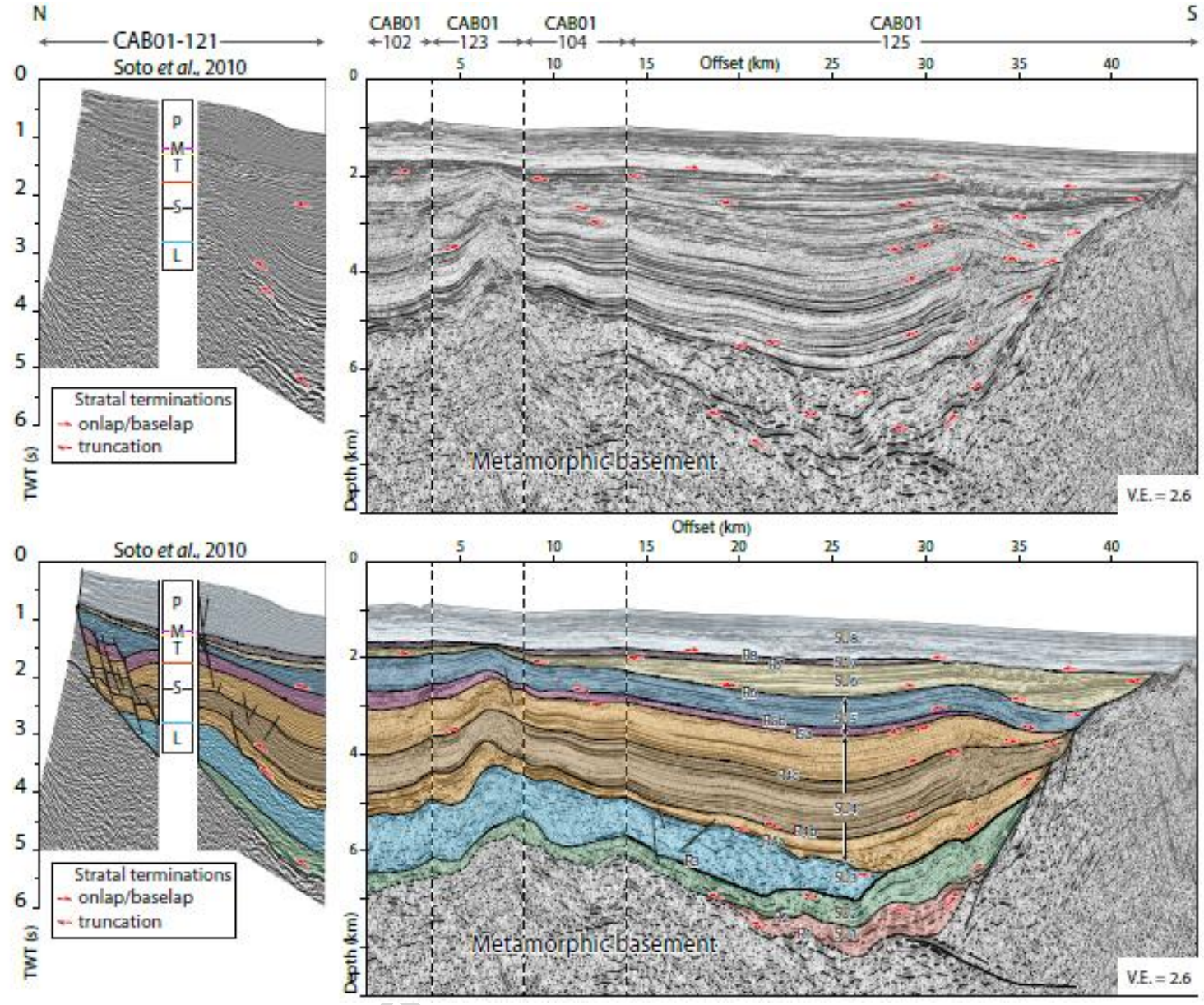

Figure 5 


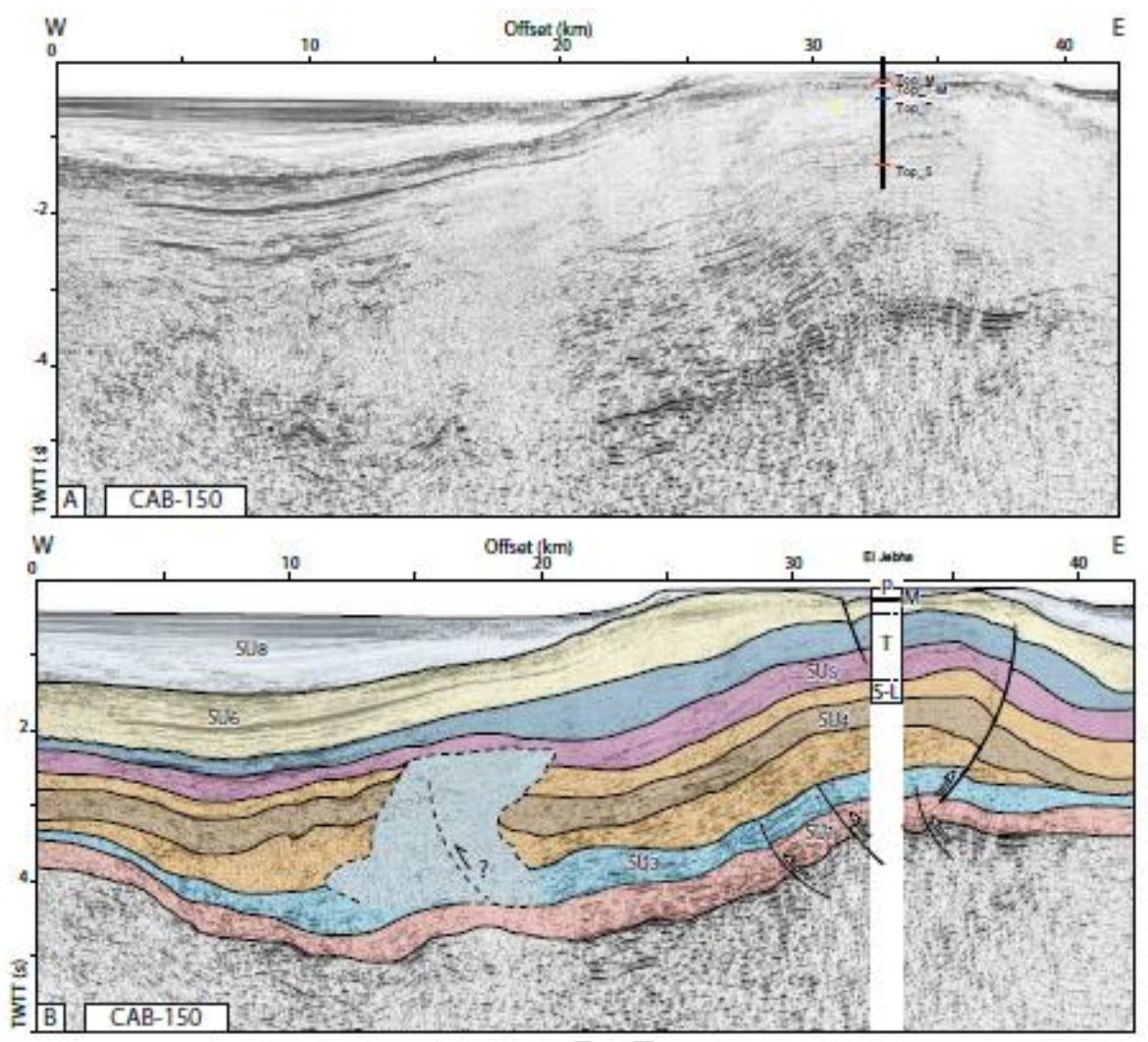

Figure 6 

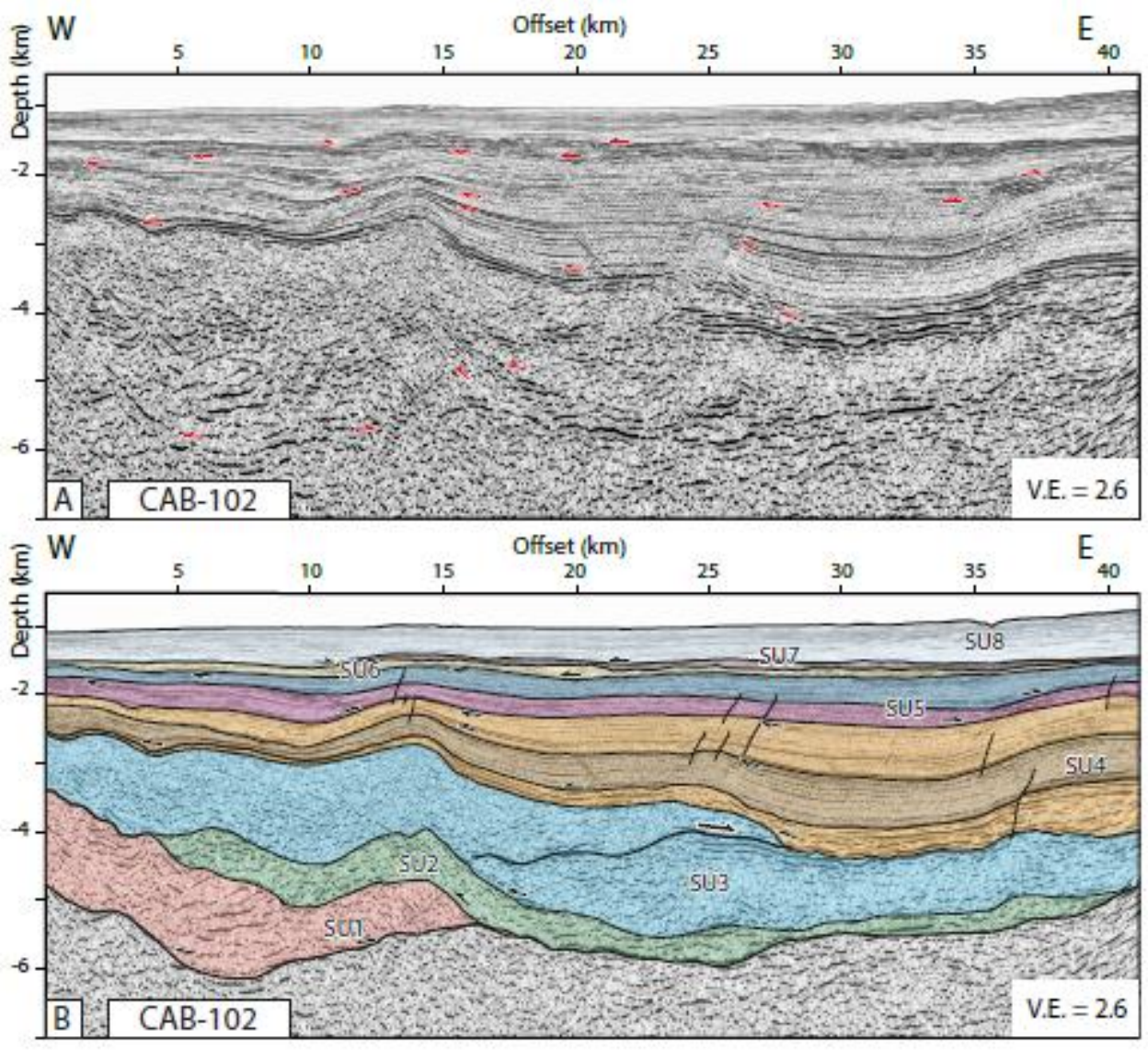

Figure 7 


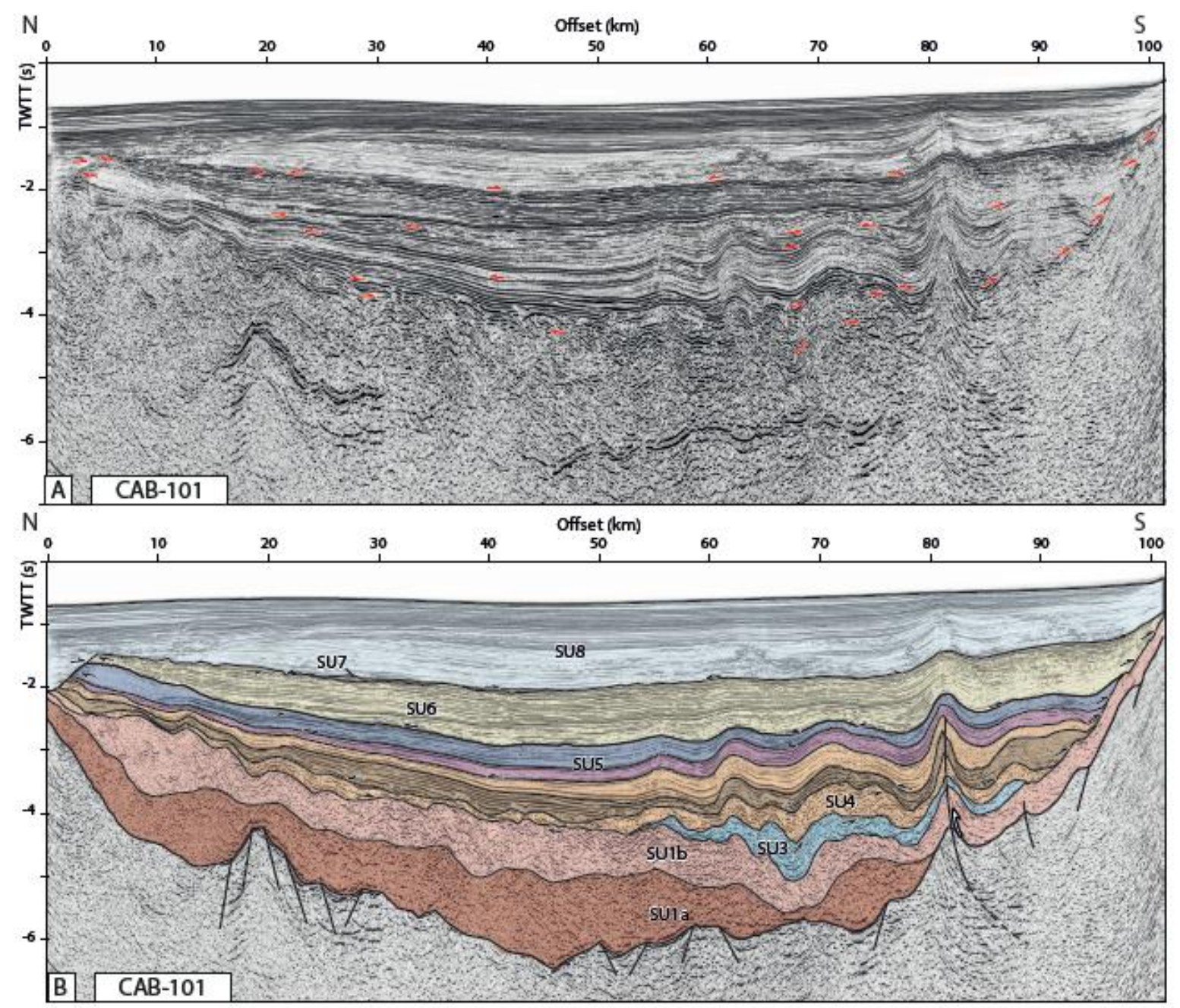

Figure 8 

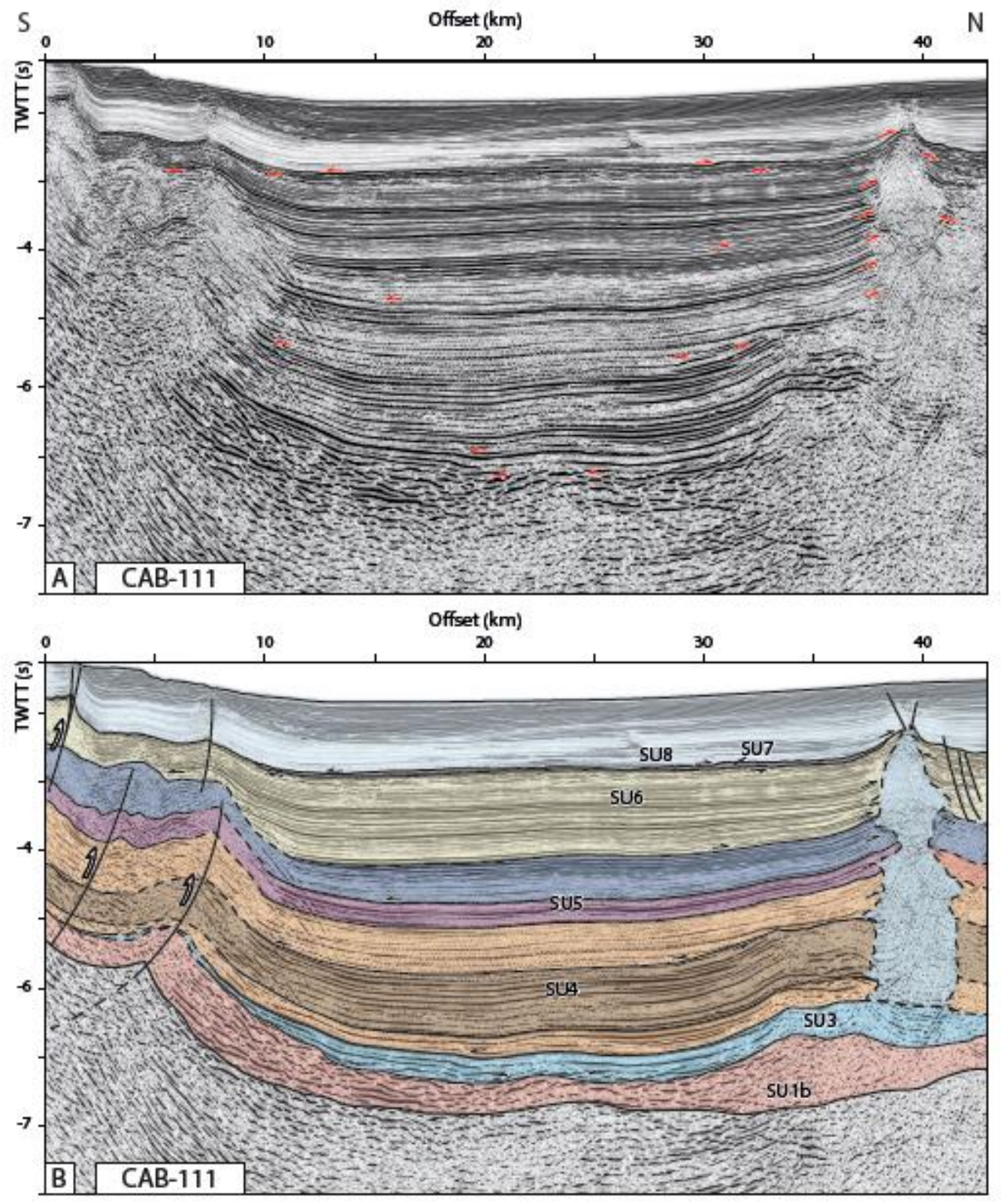

Figure 9 

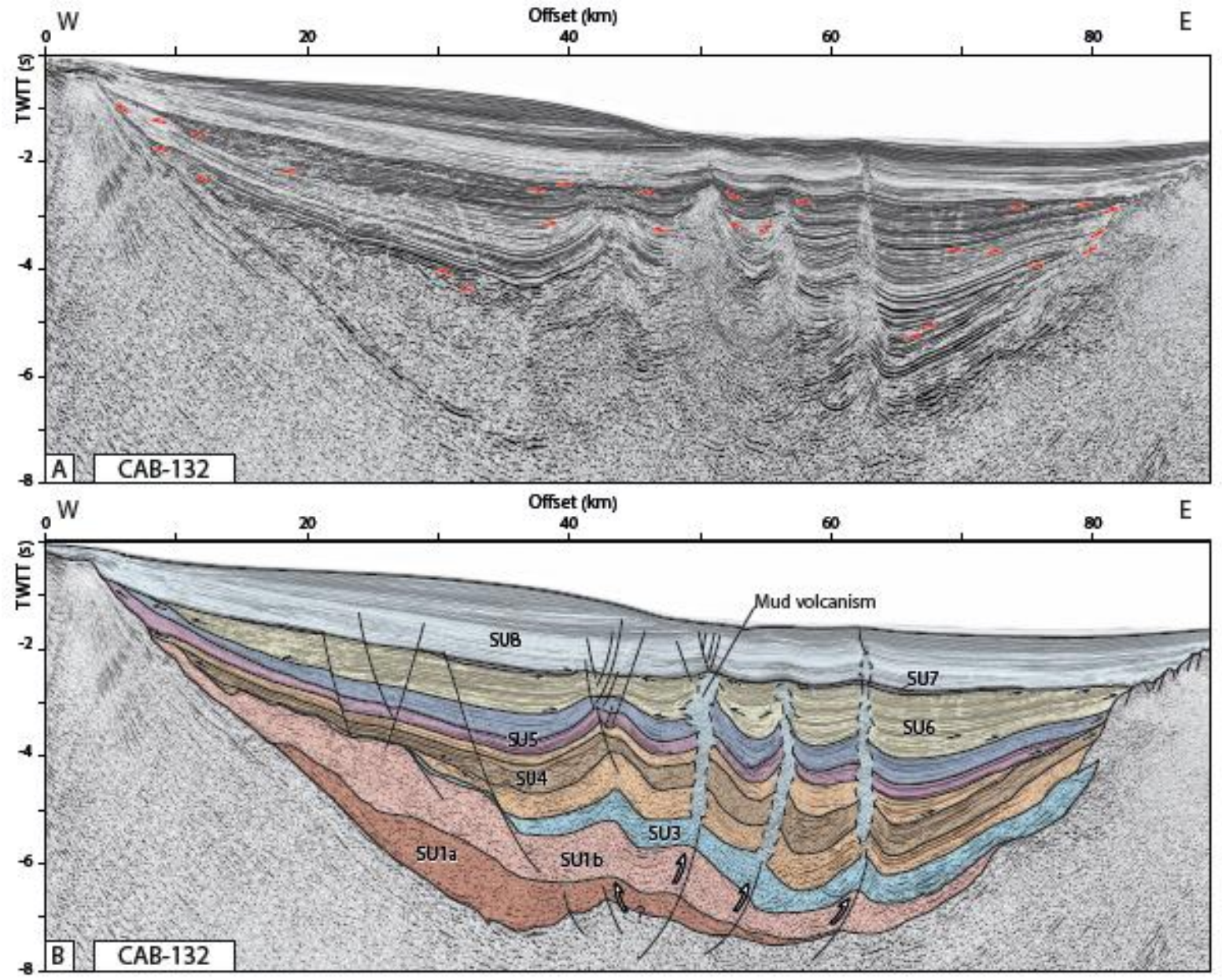

Figure 10 

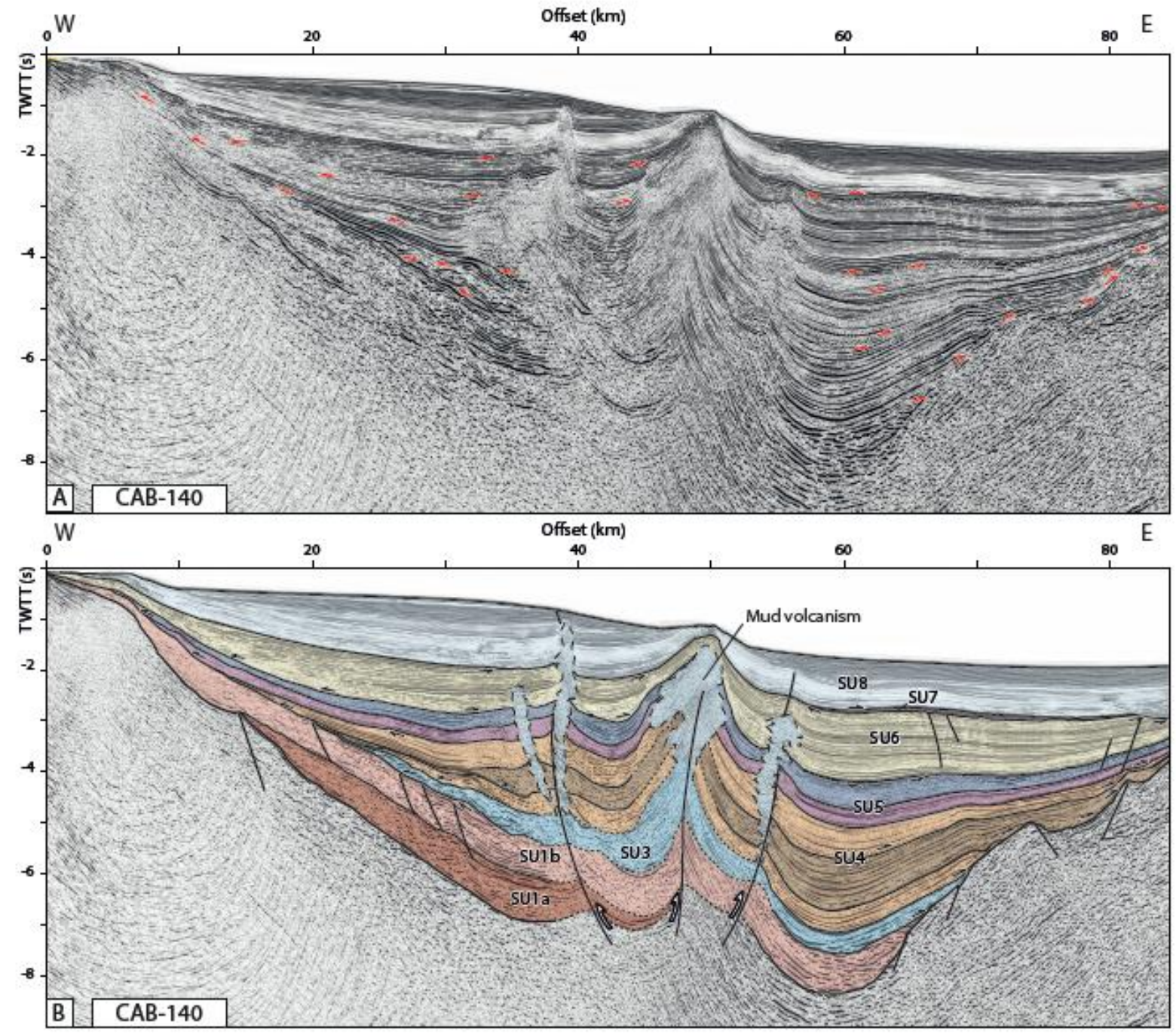

Figure 11 

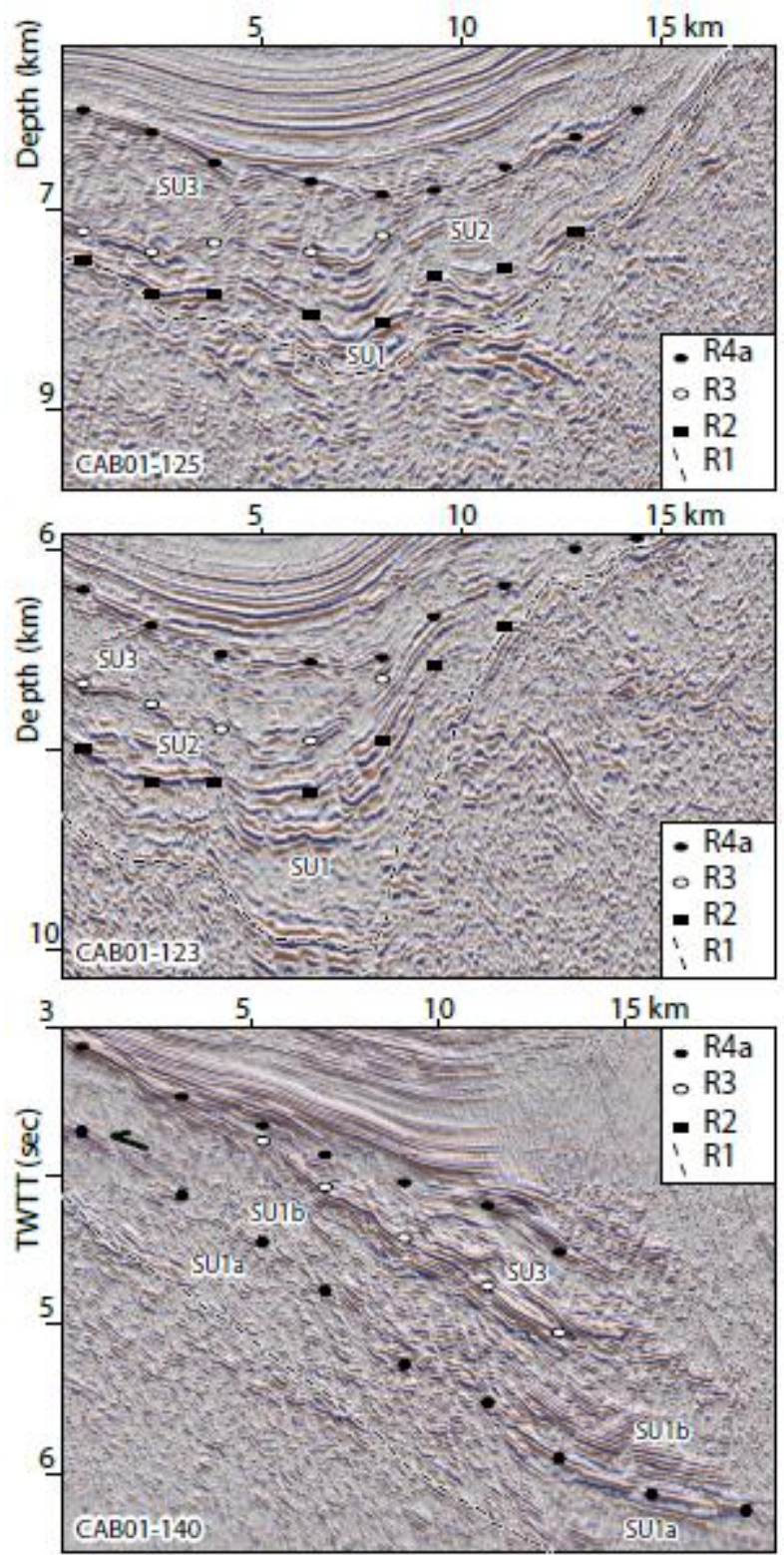

Figure 12 

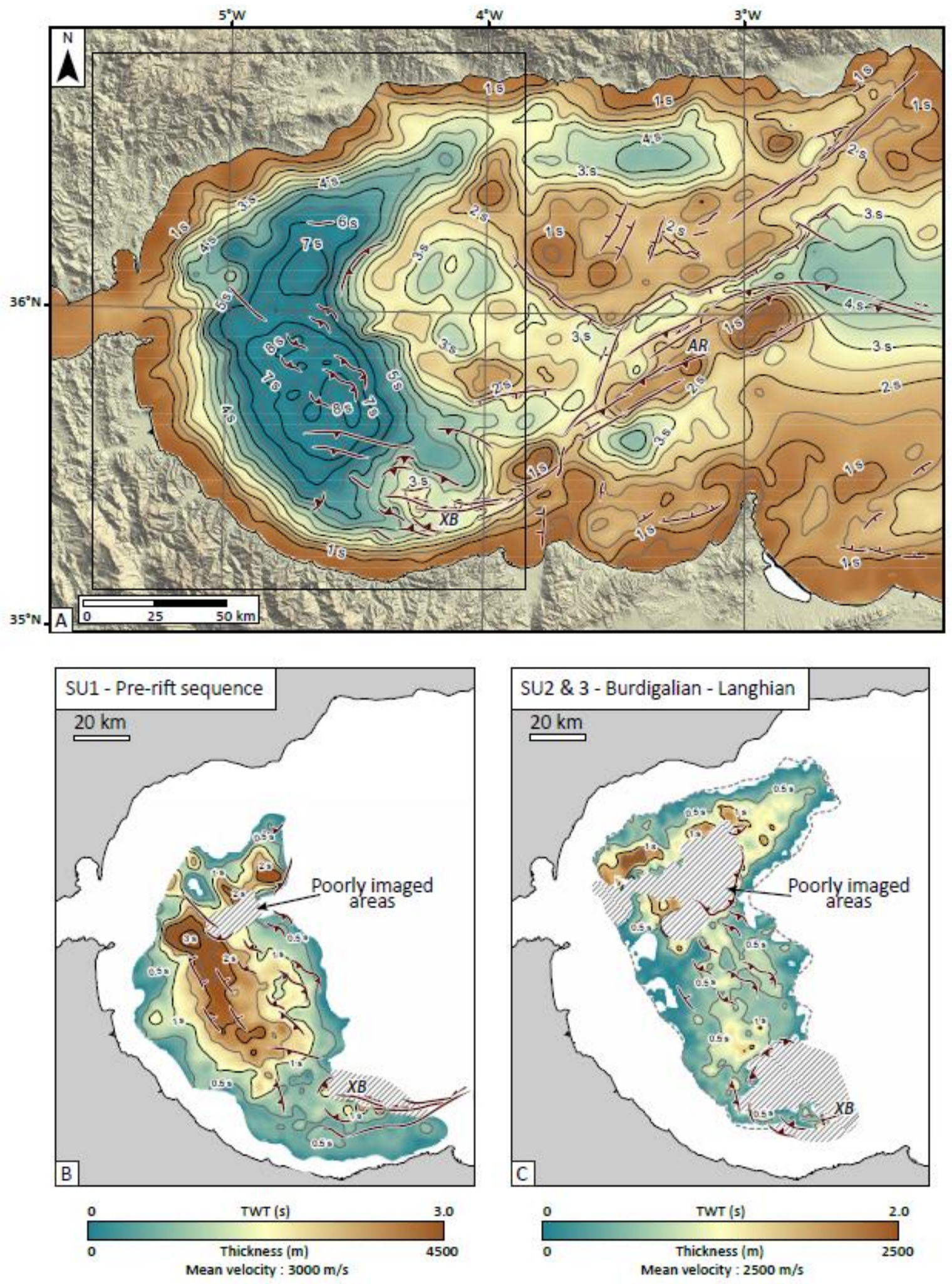

Figure 13 

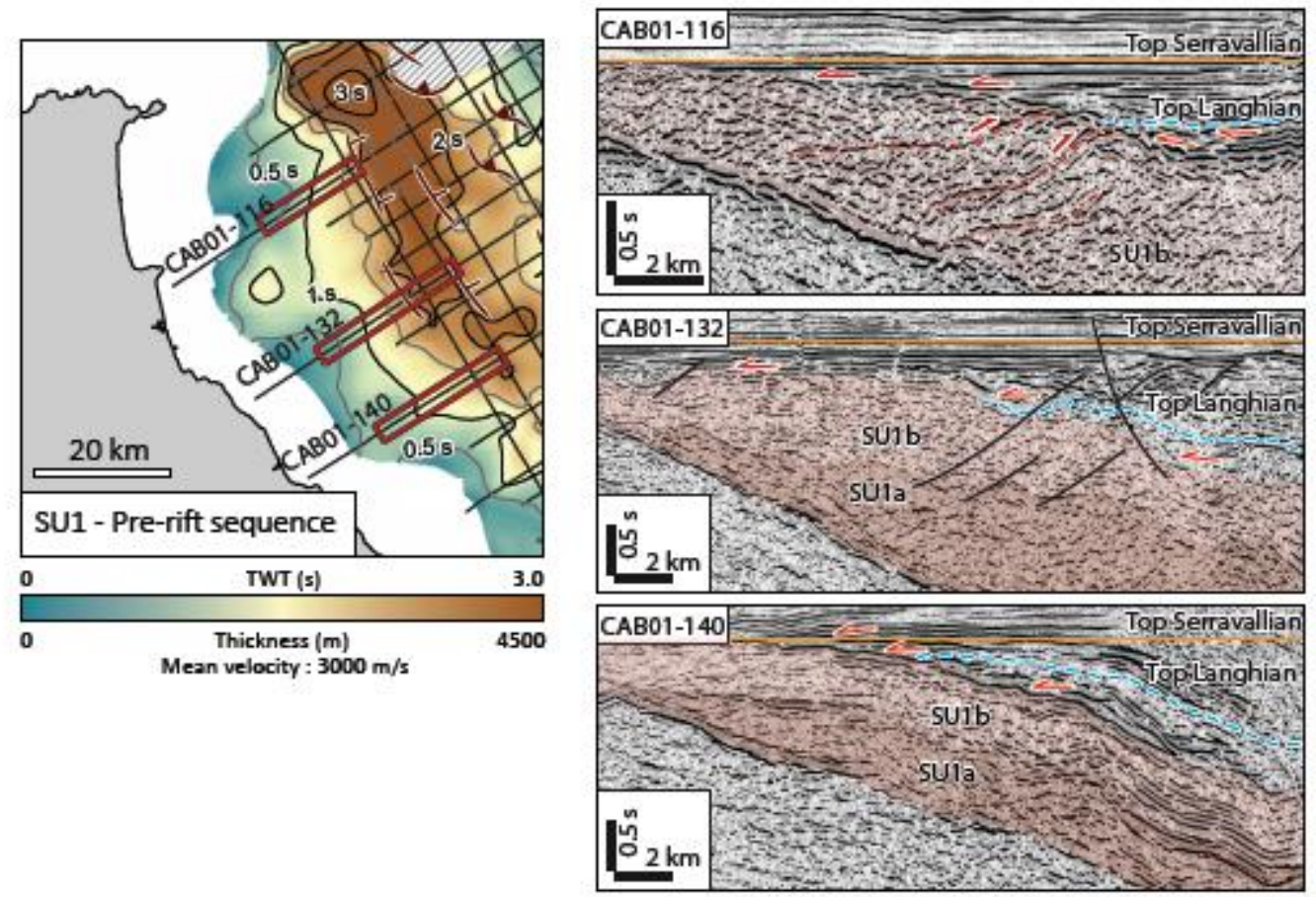

Figure 14 


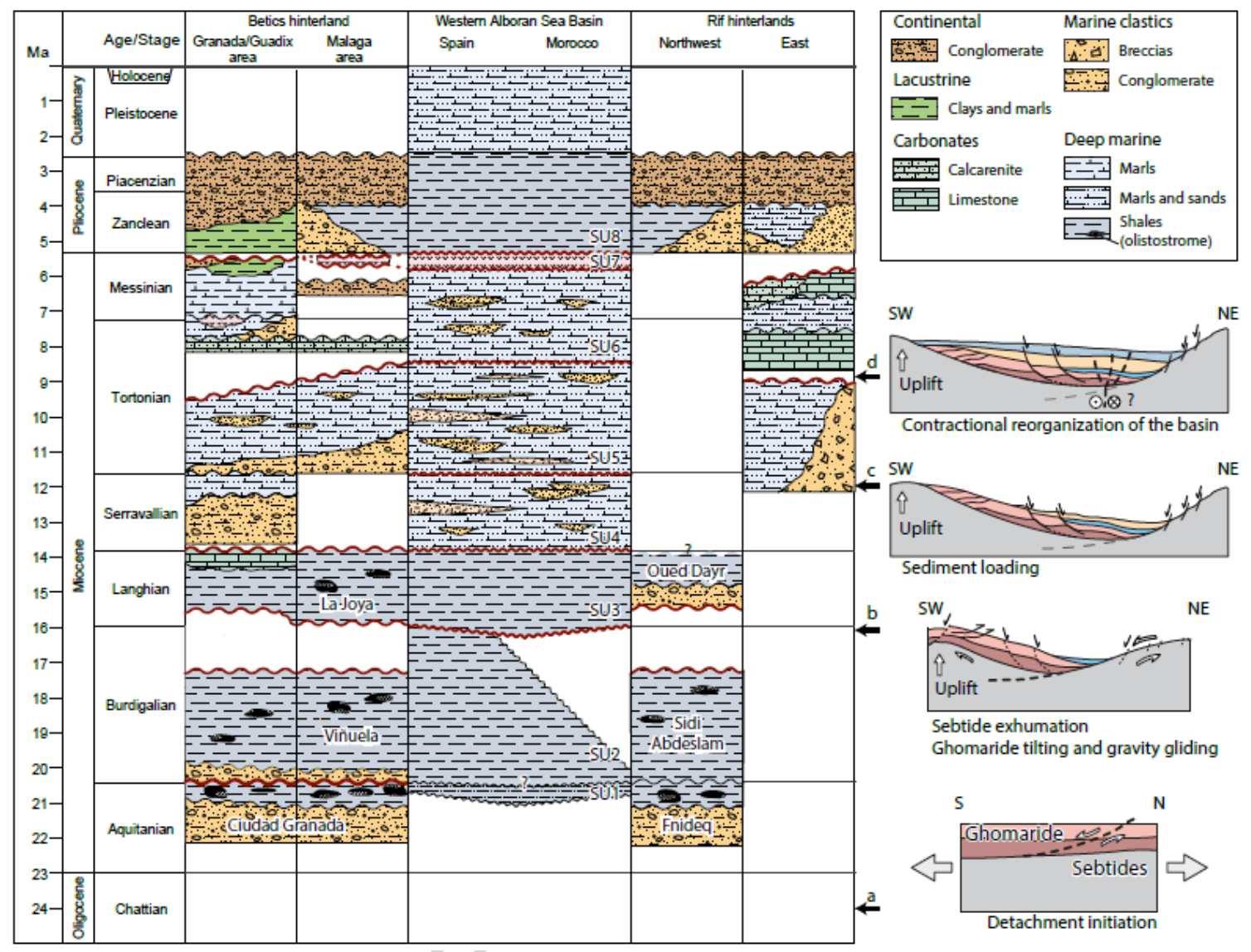

Figure 15 

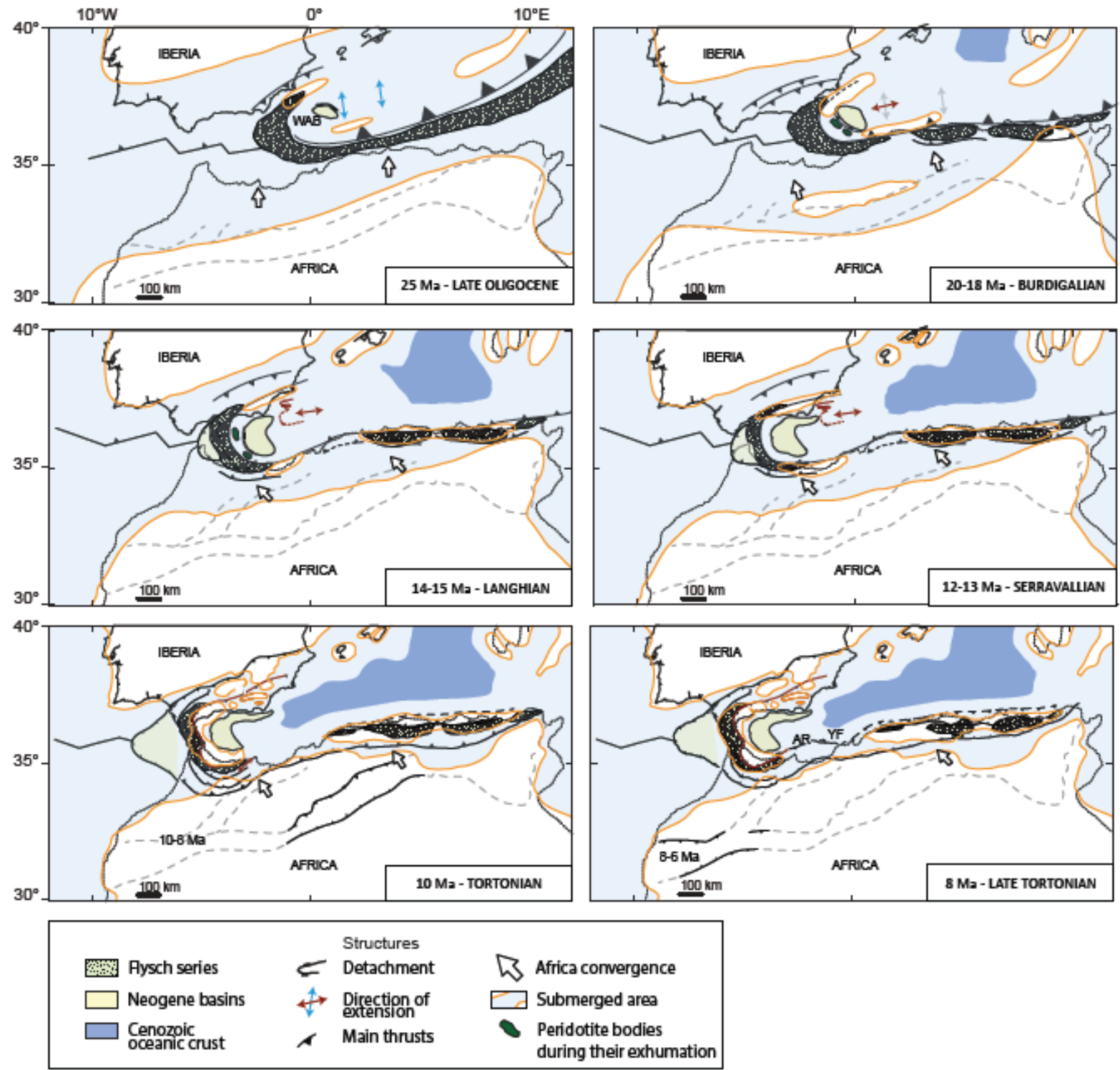

Figure 16 

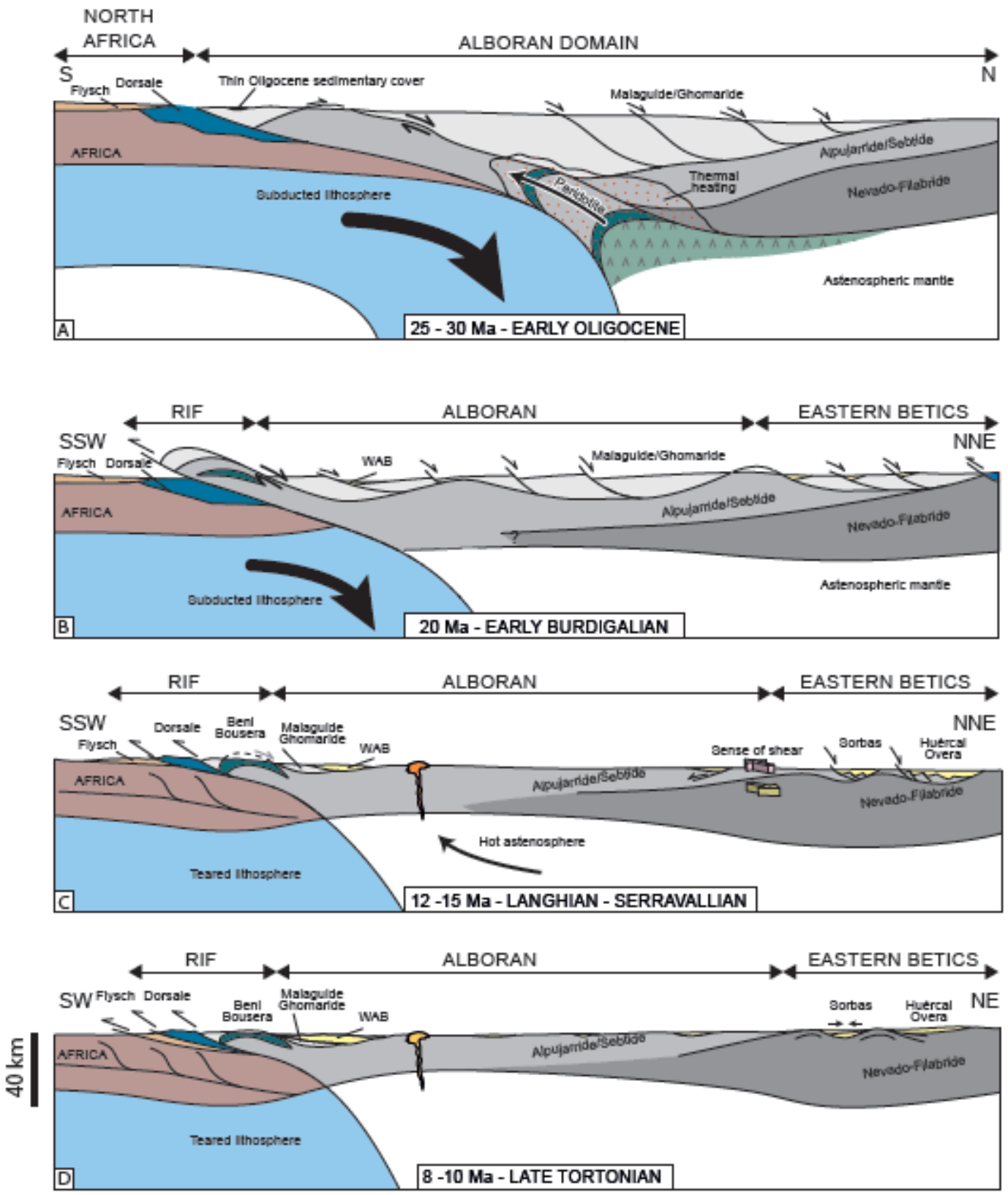

Figure 17 

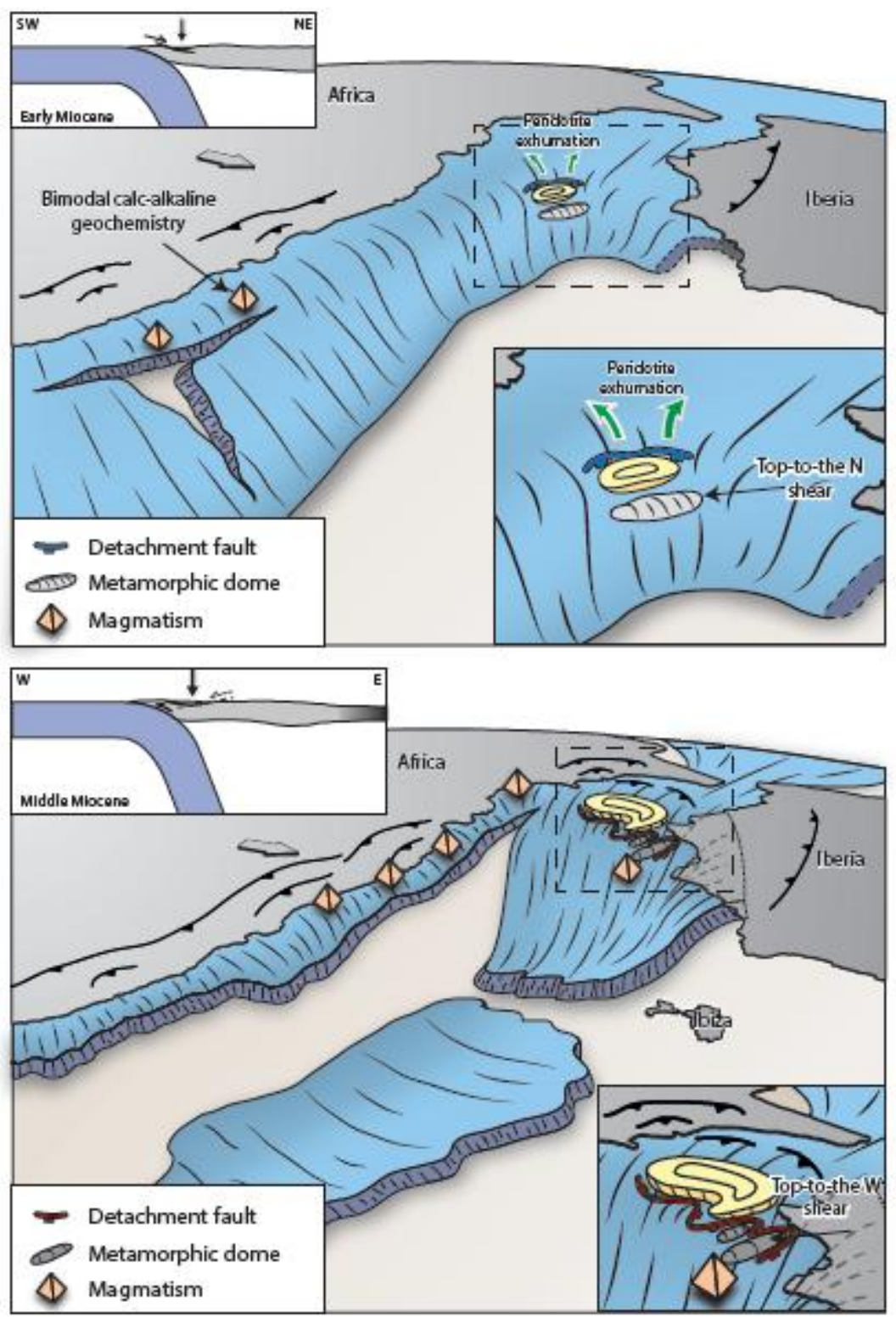

Figure 18 


\section{Highlights}

- Stratigraphic analysis of high-resolution 2D seismic allow to clarify the tectonic and stratigraphic history of the WAB.

- A three step tectonic and stratigraphic scenario is proposed based on the seismic interpretation and onshore correlations: a first subsidence pulse was probably controlled by extensional detachment; then a vertical subsidence marks a sag behavior of the WAB before its tectonic inversion in the last 10 Myrs.

- We explain that the subsidence of the WAB was controlled by the load of the dipping subducting lithosphere. 